


\section{Challenges of Development in Nibgee Village,}

\section{Ethiopia.}

A thesis presented in partial fulfillment of the requirements

for the degree of

Master of Development Studies at

Victoria University

Wellington, New Zealand

By
Tefera Alemu Tarekegn

2008 Victoria University 


\begin{abstract}
This thesis examined why the Nibgeean community, situated in a deep valley 70 kilometres from the capital city of Ethiopia, has chosen to stay in a place where travel is difficult, and amenities are very basic or nonexistent. They have remained there independently, peacefully, and relatively unchanged, for generations; largely untouched by famines and wars that have afflicted wider Ethiopia.

Various methods were employed in order to determine the points of view of the people of Nibgee and find out how they regard their own development and whether they subjectively experience deprivation. It was expected that they would feel profoundly in need of a road but direct observation, dream mapping and interviews established that they feel happy and proud as they are, and in fact their isolation is a strategic choice to maintain their self-sustainability and preserve their safe haven. Their traditional culture of cooperation, conservation and resistance to outside interference was found to have kept them safe for generations. They showed some interest in development, however, with different groups within the community showing particular interest in the development of a school and electricity.
\end{abstract}




\section{Acknowledgements}

There are a number of people to whom I would like to express my gratitude for their contribution to the fulfillment of this thesis.

First and foremost I would like to thank the people of Nibgee, who accepted my visit and educated and nurtured my mind, gave me free accommodation and food for my physical body and helped me in every matter that this research required. I hope this document reflects their voices and stories accurately. My thanks to Mr Eshete Gebre Selassie, who took me down into the valley and introduced me to the people of Nibgee, found me a place to stay and took me to the area government office allowing me to conduct this research.

My sincere thanks, also, to Prof. John Overton, my supervisor at Victoria University, who systematically helped me with structuring the thesis at all stages and, especially at the crucial finishing time, showed tolerance for my frequent questions and continually offering clear guidance.

Thanks to Victoria University for supporting me financially without which support the fieldwork may not have been completed.

Finally, my thanks go to all my family who shared my responsibilities in the house. However my deepest gratitude goes to my wife, Rachel for all her proofreading and for being the backbone of the house while I was away for my fieldwork. 


\section{Table of Contents}

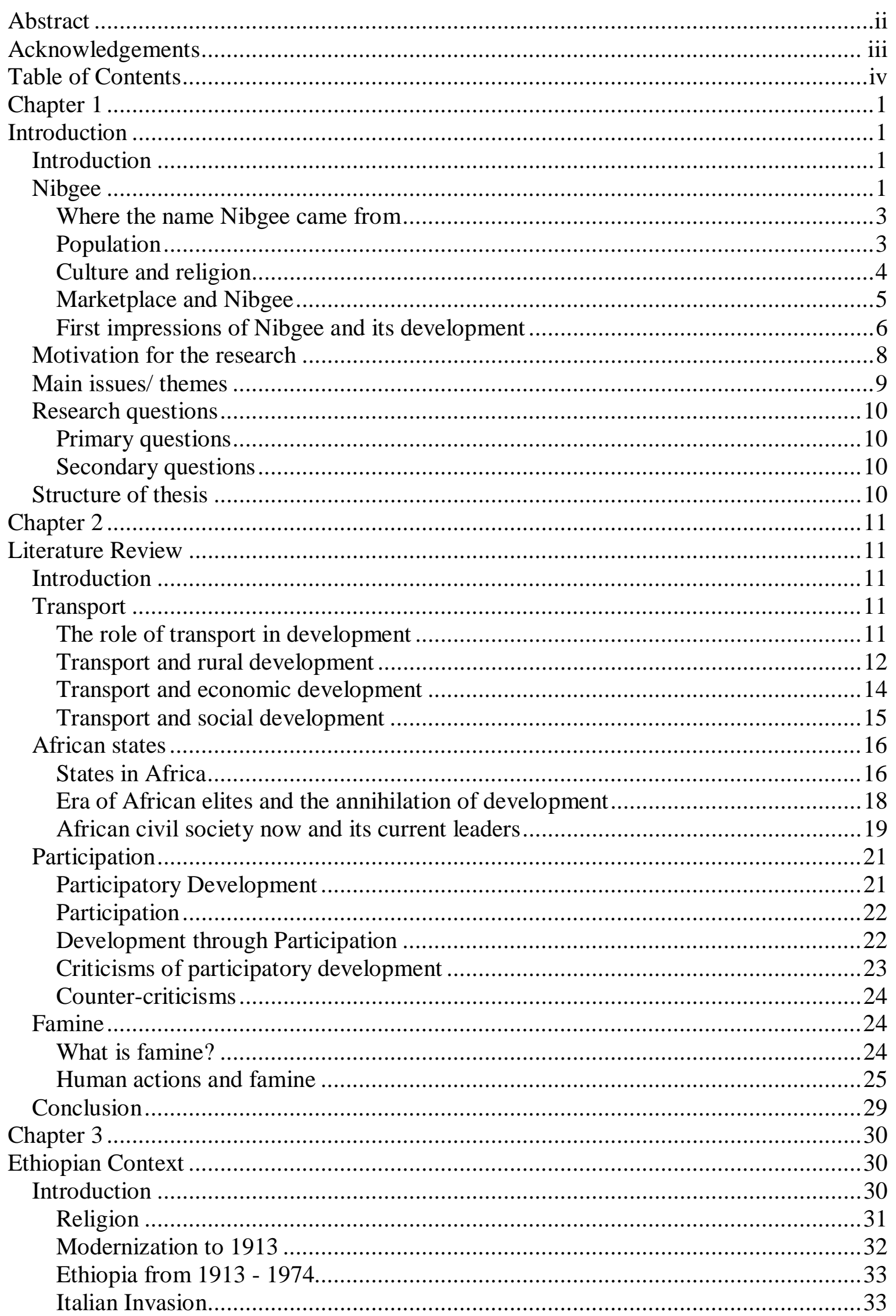




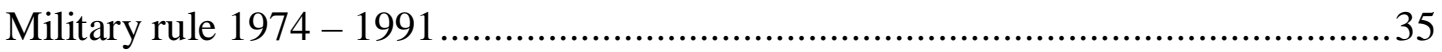

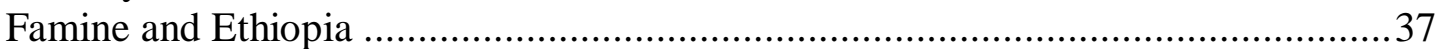

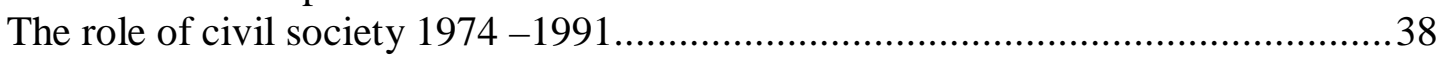

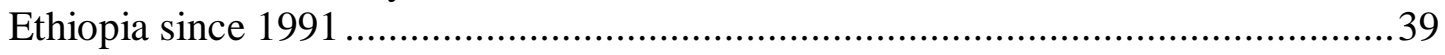

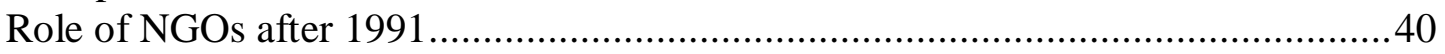

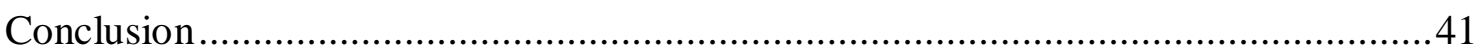

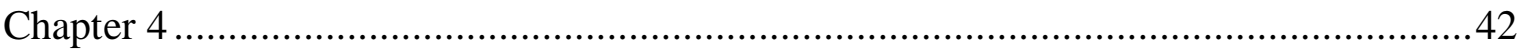

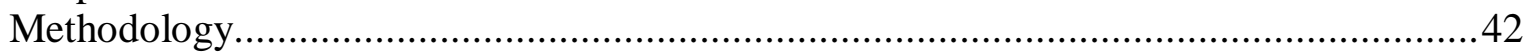

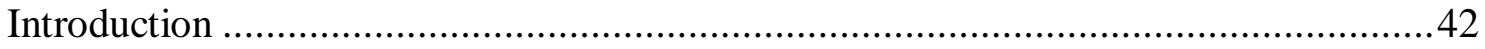

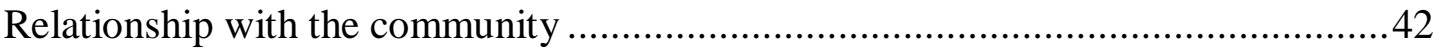

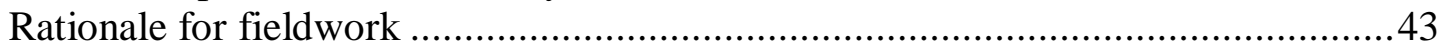

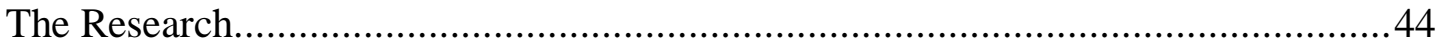

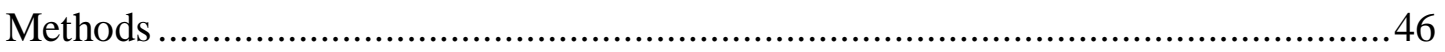

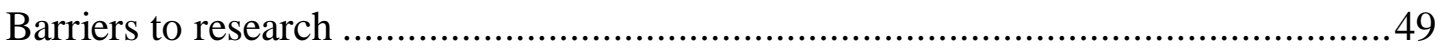

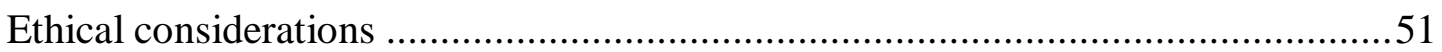

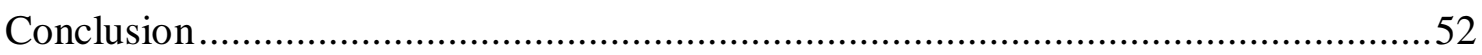

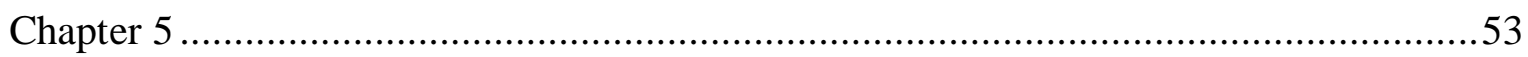

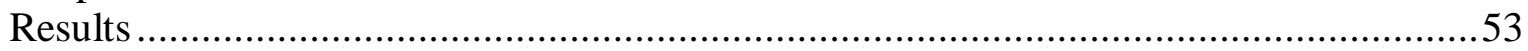

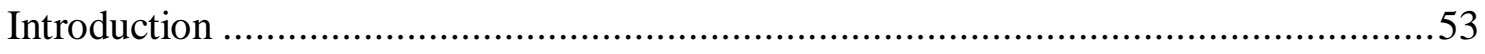

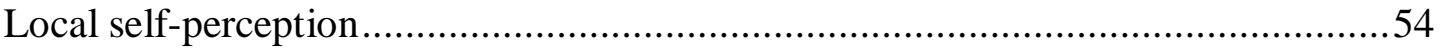

Local concepts of development ..........................................................................55

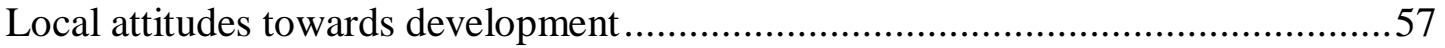

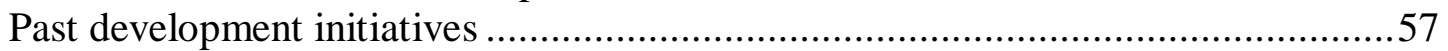

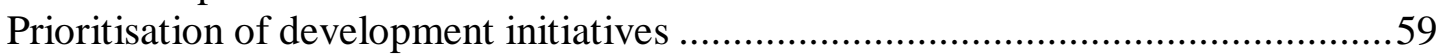

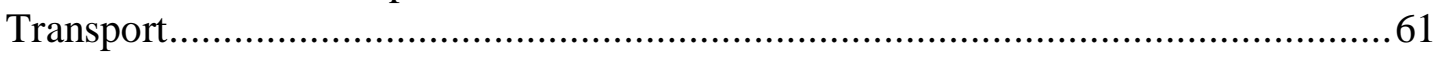

Attitudes towards the development of a road ......................................................6 63

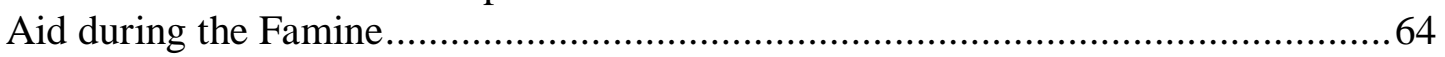

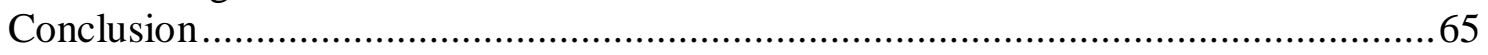

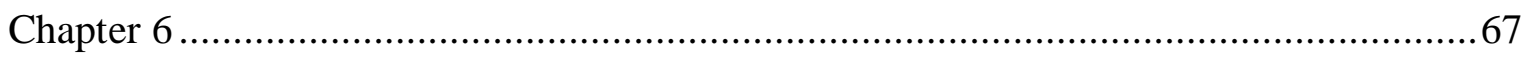

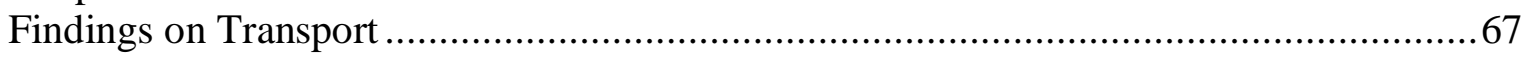

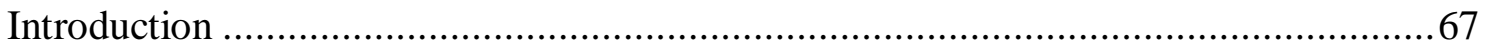

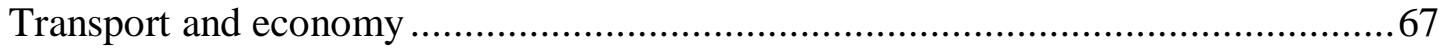

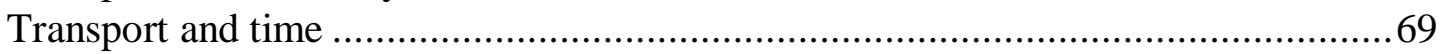

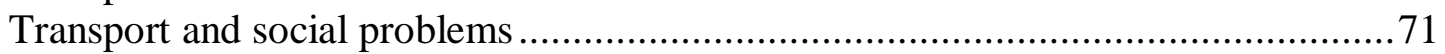

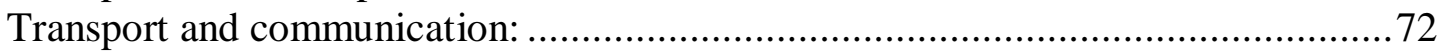

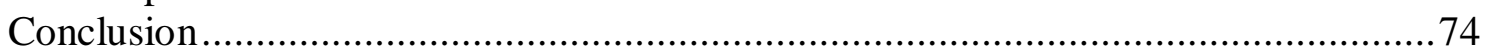

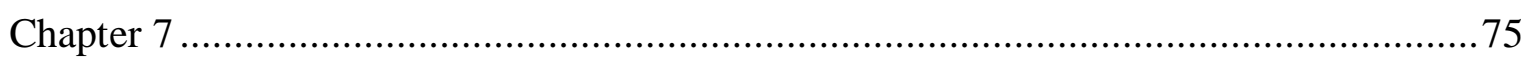

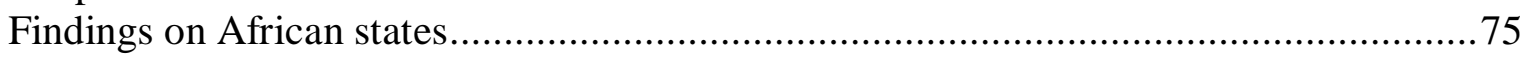

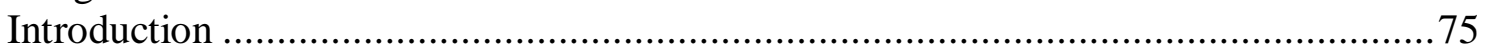

Tax as the only interaction between state and civil society.................................... 76

The church as a non-political governing power in Ethiopia...................................77

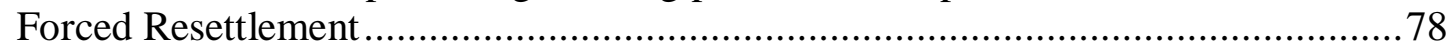

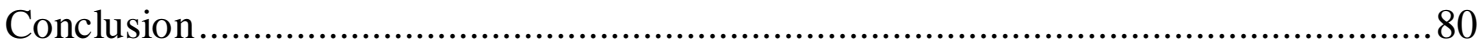

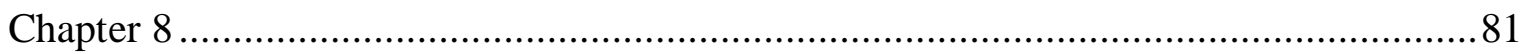

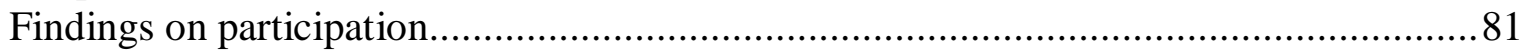

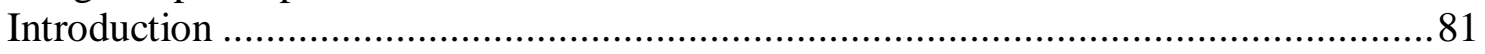

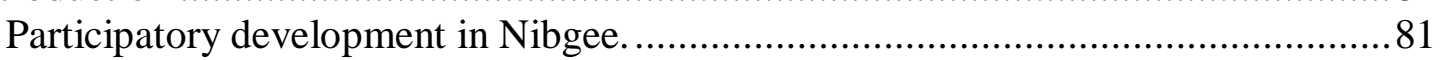

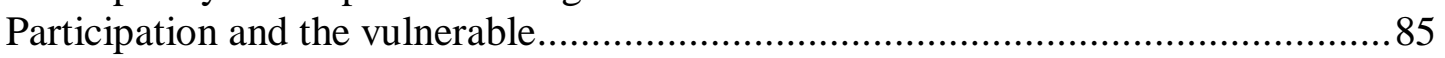

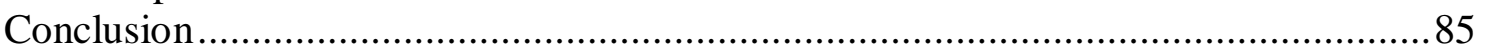

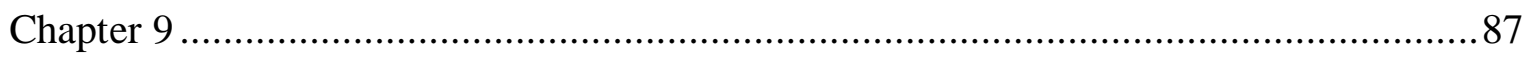

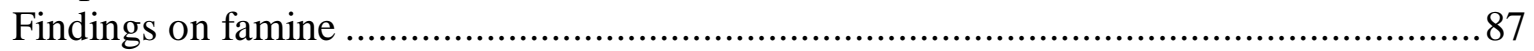

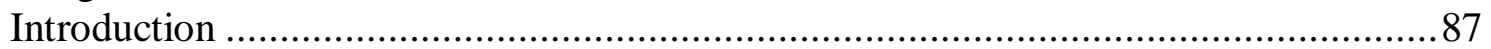

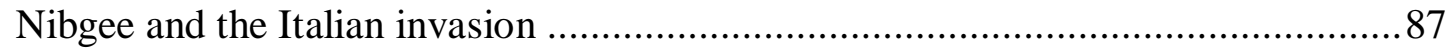

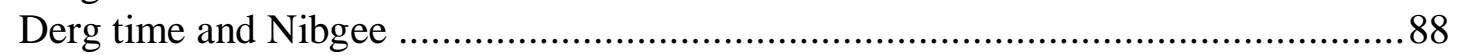




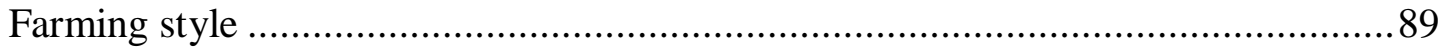

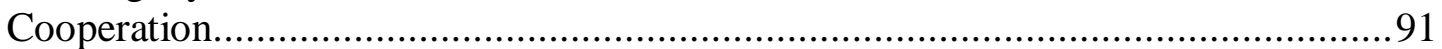

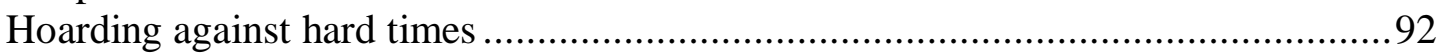

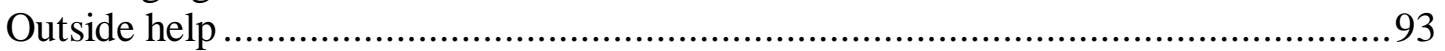

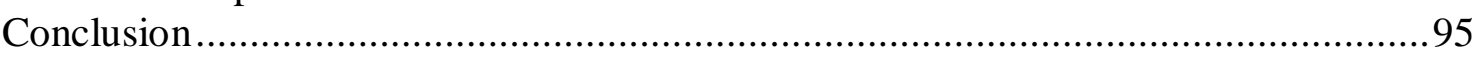

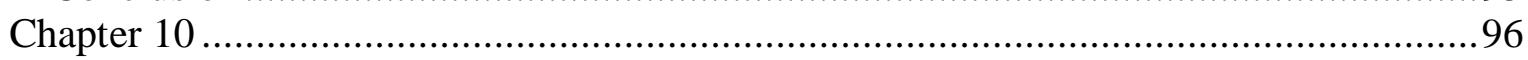

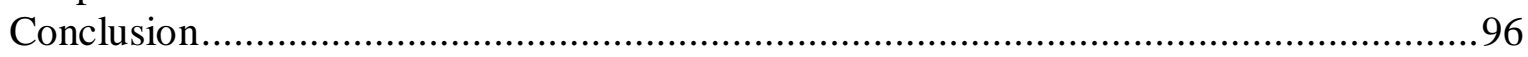

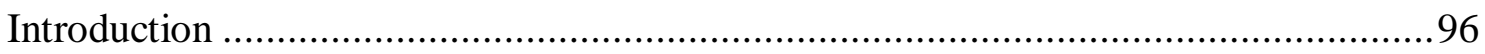

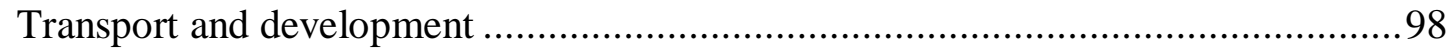

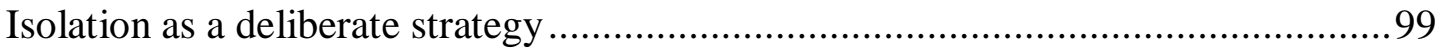

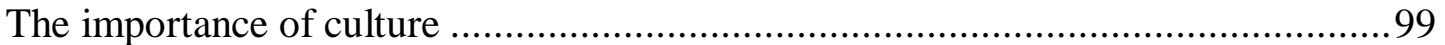

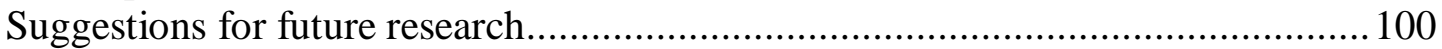

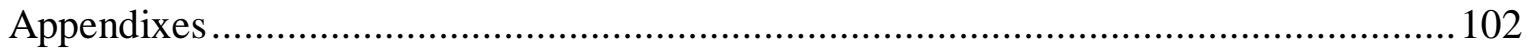

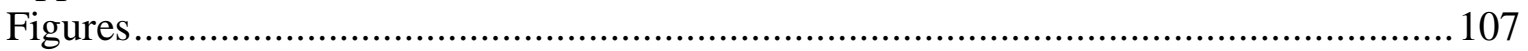

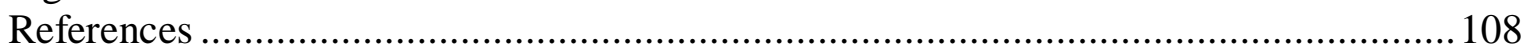




\section{Chapter 1}

\section{Introduction}

\section{Introduction}

This thesis examines why people in an Ethiopian village have chosen to stay in place and resist a number of forms of 'development'. It seeks to show how they have managed to survive in this obviously difficult area for generations even through the worst periods of famine and war that afflicted wider Ethiopia.

This chapter establishes the motivation for the research and the geographical setting and historico-cultural background of Nibgee. The simple, monastic lifestyle and isolated existence of the 700 or so villagers from Nibgee, who have survived for generations in the valley with no basic infrastructure, is particularly notable as they live just 70 kilometres away from the Ethiopian capital city, Addis Ababa. This monocultural community makes no concessions to modernity. Even a visit to the nearest market requires a walk of at least seven hours on a steep and dangerous path only wide enough for one person or animal at a time.

\section{Nibgee}

Nibgee is a sprawling village of roughly one hundred and seventy five households set deep in a valley in the Hagere Mariamna Kesem district. The climate in the valley is often desert-like, with hot, dry weather for half the year, but cold, wet weather for the other half. The landscape of the valley is sparsely dotted with trees and hardy bushes, and the steep valley walls are ridged with natural terraces. The valley floor is very rocky despite generations of farming; and goats, sheep, monkeys, wild deer and cows graze freely on the bushes and grass. Small tin-roofed or thatched houses are set widely distant from each other on their own plots of land, and it is hard to see more than three houses at a time in any place. There are a few stone fences around their boundaries but, unlike the fortresslike fences of Addis Ababa, these were more for show than to keep anyone out.

It is about 30 minutes' walk from the Addis-Makale Highway to the top of the cliff above the village. The rough road that leads from the highway to the cliffs above Nibgee is rocky, and a telecommunication dish belonging to the government is erected at the end of it. About 200 to 300 metres past the telecommunication dish along a dirt track, there is a 
cliff. It takes two hours to get down the narrow paths from the top of the cliff to Nibgee village, and more than that to get back up. The treacherous and precipitous paths are too narrow even to allow two people to walk side by side and casualties amongst the cattle using the path are a frequent occurrence.

The steepest part of the path, halfway down the cliff face, is aptly called Mot Banate, which roughly translates to "use this path at your own risk" or, more precisely, "those who use this path are responsible for their own deaths”. This does not instil confidence into first-time visitors and still strikes fear into the hearts of the seasoned travellers who come every year to celebrate the miracle of Shifudge Gabriel $^{1}$. The worst place for me, however, was the simple bridge made of four logs dropped across a stream. Rocks of various sizes were wedged here and there between the logs to fill the gaping cracks, but between them one could see the water rushing over boulders in the stream fifteen metres below. The bridge had no hand-rails and although it was short, my trembling progress meant it took a long time to cross. It seemed to me to be an ideal place to kill one's enemies and I felt wary and suspicious even of the High Priest with whom I was travelling until my feet were back on solid ground. It seemed to me that their blind faith in St Gabriel was the only thing that allowed these people to risk their lives by using that bridge. I was surprised later to see donkeys and humans confidently crossing the bridge without fear.

But still there were the cliffs. The cliffs I assumed must be an inconvenient drawback to anyone. Even without a pack, it was difficult for me to ascend or descend the treacherous and steep valley walls. So for the Nibgee villagers, carrying goods necessary for their survival either on their backs or on donkeys to and from market, I supposed must be worse. Even the closest market takes at least seven hours round trip and the Saturday market is even further away. So if they want to sell or buy anything it would take a whole day's travel. I guessed that the majority of the villagers must detest having to travel to market. Seeing the people of Nibgee apparently struggling with their loads as they toiled up and down the cliff carrying their goods made wonder why they lived there at all. It seemed obvious that they needed a road to facilitate mobility in their area.

\footnotetext{
${ }^{1}$ Literally 'Thousand-killer Gabriel.' The celebrations are held at Nibgee and attract many visitors.
} 


\section{Where the name Nibgee came from}

According to legend, as recounted by Meri Geta ${ }^{2}$, Cirak Taffere and Abba ${ }^{3}$ Gabre Mariam Tassew, the name Nibgee was given to this village after a strange tribute was offered to the church prior to the $13^{\text {th }}$ Century. In old times, the church had ultimate power over its followers in the whole of Ethiopia, including this area. Then, as now, the locals of that valley had no money so the villagers gave tithes to the church in the form of food. In those days, a common offering was honey, but one day a church follower brought bees instead. When the church people asked him what he had brought, he replied, "I brought bees". From that time onwards the area has been named for the Amharic word 'Nibyze ${ }^{4}$, meaning 'come with bees', which, over the centuries, has been shortened to 'Nibgee'.

The church of the angel Gabriel is the religious centre of the Nibgee community. Initially once a year, and, since 2005, twice a year, people from all over Ethiopia have come to celebrate the festival of the angel Gabriel at this church, but many pilgrims give up and pay their respects from the top of the cliff rather than risk walking down. According to local tradition, at some time in history there was an attempt to shift this festivity and the church to the flat land at the top of the cliff as it was difficult for followers to get down into the valley. However, thousands lost their lives in the attempt and finally left the church where it was; whereupon, legend has it, the calamities stopped. Hence the name 'Shifudge Gabriel’ or ‘Thousand Killer Gabriel’ was given to that church.

\section{Population}

There are no official books or maps defining the exact size of Nibgee. Even though it is surrounded by mountainous cliffs, according to Ali Wenze's Watershed Management based map ${ }^{5}$, it has four neighbouring villages up the hill. These are: Agdu and Tuloffa on the western side and Guy and Cherrign on the southern side [Appendix 1]. There is no official record of the exact number of people living in Nibgee. According to the records of a government office ${ }^{6}$ situated near the highway at the top of the hill, the combined population of a nearby village called Guy and Nibgee is over 1,137 [See appendix 2]. This office's records show that as of 2005 there were 244 households in Guy and Nibgee. Of the heads of households, 49 [20\%] were female led households and 195 [80\%] were

\footnotetext{
${ }^{2}$ Scholar in the doctrines of the Coptic Orthodox church.

${ }^{3}$ Father or monk who has dedicated his life to the monastery at Nibgee.

${ }^{4}$ Amharic word for bee is 'Nib' and 'Nibyze' means holding bees.

${ }^{5}$ I found this map in the government office at the top of the hill.

${ }^{6}$ The local Agriculture and Development Station up the hill Ethiopian Calendar year 1998 census of animals and humans.
} 
male led households. There were 413 subordinate males and 480 subordinate females living in Guy and Nibgee at that time, totalling 1137 people altogether, meaning that the average sized household would comprise between four and five people.

The census also included a record of livestock. There were 1,986 head of cattle; 298 sheep, 1,375 goats, 246 donkeys, 5 mules, 620 chickens and 21 beehives. According to that census, Nibgee and Guy were suffering from a scarcity of grazing land and animal fodder. Githinji and Mersha (2007) stated that this is typical in the Northern part of Ethiopia because they lack modern farming methods and up to date production technology. Thus the people of Nibgee, like the majority of farmers in Ethiopia, are still subsisting below the poverty-line (Githinji and Mersha 2007) [Appendix 2]

\section{Culture and religion}

Nibgee is a mono-cultural society. It is a part of the Shewa province where the Amhara live. The Amhara are the ethnic group that ruled the whole of Ethiopia from the 19th century until mid-20 ${ }^{\text {th }}$ century (Pankhurst 1992; Githinji and Mersha 2007) and they are still considered to be the elite of the country. The last three monarchs came from this part of Ethiopia. In the whole of Ethiopia there are more than 96 languages (Hancock 1985) and most people are at least bilingual but the villagers of Nibgee are monolingual, speaking only Amharic which is the official language of Ethiopia. Furthermore, all of the people in Nibgee are Coptic Orthodox Christians and there is no other religion or denomination represented there. In fact 'Shifudge Gabriel' is the only church in the valley.

Nibgee reportedly became a pilgrimage destination for Coptic Orthodox Christians after Saint Kewstous ${ }^{7}$, cousin of well known Ethiopian Saint Tekle Himanot ${ }^{8}$, dreamt that the valley was holy and settled there in the $13^{\text {th }}$ Century. This momentous event was written about in 'Gedle Kewstous' or Life of Kewstous [Appendix 3] which was handwritten in Geez ${ }^{9}$ in the $13^{\text {th }}$ Century. 'Shifudge Gabriel' is becoming a more well-known destination for miracle-seekers as word spreads about healing or blessings people have received after visiting there. But apart from the influx of visitors for the biennial festival of Saint Gabriel, only locals and neighbouring villagers worship at 'Shifudge Gabriel' church. This is despite the fact that in Nibgee, out of respect for the many Saints days, Angels

\footnotetext{
${ }^{7}$ Saint Kewstous was the one who built Shifudge Gabriel church.

${ }^{8}$ Translated by Meri geta, Cirak Taffere and Abba Gabre Mariam Tassew

${ }^{9}$ The Amharic language driven from and still church people use it.
} 
days, Sabbath days and other Christian festivals, more than half the year is considered to be a holiday.

Although the culture of the Nibgee is mainly framed by the influences of Coptic Orthodox Christianity, which follows the principles of both the Old and the New Testament, the practicalities of farming play an equally important part in shaping their lives. As any farmer could attest, they need to tend their cattle, sheep and goats every day whether it is a holiday or working day. Horticulture also keeps them especially busy during harvest season. But on holy days crops have to wait.

Each family's grass area, which they use for their animals and crops, was decided on by the local government following the Communist revolution. This is supplemented by allowing the animals to forage in the unassigned forest areas. Even though they have individual houses and land, most of the work is done communally with each man, woman and child helping the others and reciprocating when others help them. Even the children work on the farms. I never saw a ball or a skipping rope or even children playing. Everyone was working. It was the children's responsibility to guard the cattle. Most children only go to school up to third grade but are kept home to work whenever the family needs help. However, a few families are happy to send their 'extra' children to the capital city for further education if they feel there are enough children at home to help them with their day-to-day activities.

Nibgee's people seem peaceful towards each other. The majority of the inhabitants do not even keep their goats separately in barns or paddocks except at night, but leave them in the hills running together all day as they know their own animals. That shows the high degree of trust they have in each other. However, they are reserved with outsiders at least until they ascertain their motivation.

\section{Marketplace and Nibgee}

In Nibgee there is no market or shop to purchase even a kilo of salt or to sell a kilo of grain. They have no banks or anywhere to access money easily, so even when the time comes to pay the church, they tithe crops such as teff [millet-like cereal used to make the Ethiopian staple food: injera (Leslau 1992) ] , wheat and barley. The nearest market is up the hill and the closest one takes a minimum of three and a half hours to reach from their village and is only open once a week. As there are goods to be carried both ways on that 
steep and precipitous path, it seemed to me as an outsider that the improvement of transport infrastructures in a place like Nibgee would be helpful. Hilling (1996:157), recognized the vulnerability of communities which do not have roads. They are forced to sell food crops cheaply, which is why the burden of travelling is left to them as no one else benefits out of their products. To illustrate just how poor this community is, even a matchstick is a luxurious item, so they keep their fires burning 24 hours a day all year round. Cattle manure is the preferred fuel for keeping the fire alive although this creates a large amount of malodorous smoke. There are no basic infrastructures such as clinics, sewerage or septic tanks, water collection points or electricity in Nibgee. The women laboriously dip tin pots into a spring to gather water to carry home on their backs. The cattle, however, are taken to the stream to drink.

\section{First impressions of Nibgee and its development}

When I first looked down at the miniature landscape at the bottom of the huge cliff, it looked like a painting or model village of some artificial place. It was hard to imagine how anyone could manage to survive in that deep, steep valley or even to envisage life in there at all. The hills seemed too steep to plough and the soil so rocky it seemed impossible that crops could grow there. The only form of entertainment in the village was the daily church service. My first impression of Nibgee village led me to wonder at how people could survive in that inhospitable place for so many centuries; living in the same way with so few amenities. I also wondered who forced them to stay in that unappealing place.

This was in part answered by an old man whom I met on the celebration day of Shifudge Gabriel, when I attended the church ceremony. The old man invited me to be his guest at the end of the ceremony and told me how the rugged surroundings had saved his life during the Italian invasion. Also, his children were saved by the same topography from compulsory conscription to military service during the Communist Revolution. He added that if anything happened in the future, his grand children would be safe so long as Nibgee remained inaccessible.

It seemed, from my perspective as an outsider, that Nibgeeans were relatively poor but I also got the impression that they did not want any assistance. They seemed to have negative perceptions of development and they were suspicious of outsiders. They seemed to think that outsiders came to the area, not to help, but with their own agendas, namely to 
expose them to unwanted confrontation with the government, to spoil their religion or to expose their safe haven, which has historically protected them from danger. As one old man said,

"Look, in our place we work more than the people who live at the top. The lifestyle and isolation have made us courageous and strong enough to face any type of challenge...... We are happy about what we have and we do not want anyone who tries to jeopardise our safe haven.” [Personal communication 29/12/05]

The people of Nibgee consider themselves to be 'Kolegna'10 (Leslau 1992), and characterise themselves as hard workers who are courageous in the face of any eventuality compared with less hardy 'Degegna' ${ }^{11}$ (Leslau 1992). They appear to think themselves better off than the Degegna despite the apparent hardships incumbent in the rigorous trials of their daily lives. Sometimes they even use the word 'Degegna' as an insult. One local man said disparagingly that the Degegna are the dogs of the government.

I asked the gentleman who offered me the meal what responsibility the government has to this part of the country and what sorts of NGOs there were to help this vulnerable community. He cynically offered the following opinions about NGOs but he was understandably reticent about the government, as I was a stranger.

"They are doing it for their own sake by exaggerating the problems. Their ultimate goal is to persuade us to convert to their way of Christianity. We flogged one organisation representative who presumed to offer to a clinic up the hill on the first day of introduction so we sent him away. That is not only a one time phenomenon. Many tried but in return they got a clear message from the people. We do not want them and they do not care about us.”

This would seem to endorse view of some scholars who argue that the ultimate desire of aid agencies is to endorse the donors' religious ideologies or political systems or to ensure the receivers support them in the international framework (Hope 1996:154). It also explains in part why people choose to live there as their religious community is largely isolated and therefore protected. But I still wondered if this was enough to counteract the

\footnotetext{
${ }^{10}$ Kolegna is a person who lives in the valley; an inhabitant of the lowlands.

${ }^{11}$ Degegna is the label given to people who live in the flat land where it is easy to farm or to fetch water. It translates as 'Highlander'.
} 
inconveniences and discomforts of their impoverished existence. I wondered whether they believed as many in Ethiopia do, that their poverty is the unavoidable result of a curse.

Foreign aid agencies and development scholars argue that Ethiopian impoverishment is stems from human error. Even the last Emperor of Ethiopia, the late Haile Selassie I, said: "There are always inequalities among people: people who work hard, harvest a lot; people who are lazy starve”(Devereux 2003:14). Selassie used this logic to defend himself against international condemnation of his extravagant overspending policies. But, according to the old gentleman from Nibgee, Ethiopia's poverty is not due to a lack of diligence, but is a curse from God. As such, poverty and starvation seem to be accepted not resisted. He quoted verses from the Bible ${ }^{12}$ that helped me to understand his point of view about wider Ethiopia’s famine problem, but surprisingly he, like most others I talked to, did not feel affected be this 'curse' in Nibgee. Rather, they seemed to feel blessed to live there.

The old man lived in a big round cottage typical in the Hagere Mariamna Kesem district. Except for the nails and hinges, all the other building materials came from the bush: mud and straw for the floor, manure for the polish, sticks for the structure, thatch for the roof and wood for the shutters. The cottage consisted of a single room where they cook, eat, sleep and talk with their friends. As far as I could tell, nobody in Nibgee used partitions or screens in their homes even when many people lived in the same room. One could easily identify the bedding made of animal hides stretched over wooden frames but not everyone slept inside. Some people slept in small lofts at the top of outside lean-tos. The seats were all fixed to the floor, and were made of stone and mud and there was no table. Even the new government school chairs are fixed with mud and there are no desks. The house was clean and plastered with cattle manure. The old man's cottage had no toilet. In fact there was not a single toilet in the whole village. They have fixed times and places to relieve themselves, using their own farmland early in the morning or late at night.

\section{Motivation for the research}

My desire to find out about Nibgee's inhabitants arose in 2005 after I had completed my Post Graduate Diploma in Development Studies. I had admired Nibgee's topography every time I went there to celebrate the annual festival of Gabriel. However, I always

\footnotetext{
${ }^{12}$ In the Bible, Psalm 68:31 says, "The Ethiopians will raise their hands in prayer to God”. In another chapter, Jeremiah 39:15-16, the Lord says to Ebdemelech the Ethiopian, "Just as I said I would, I am going to bring upon this city [Ethiopia] destruction and not prosperity. And when this happens, you will be there to see it” Bible, Ed. (1992). Good News Bible: Today's English Version. Wellington, The Bible Society in New Zealand..
} 
wondered how they had survived from generation to generation especially during the devastating famine of the 1980s (Hancock 1985; Lautze and Maxwell 2007). I also wondered how they could endure such a basic lifestyle in this modern era.

'Who forced them to be there?' was also another crucial point to be answered. In Ethiopia there was forced settlement, which did not happen to this village and currently there is the option of voluntarily resettlement but no one takes advantage of that either. There is no equivocation regarding this point. While I was there no-one complained. I got the impression that they felt safe and comfortable there and that the older people do not even see why they should want to live anywhere else. They want to be buried in Shifudge Gabriel and do not want to shift their funeral ceremony to a less holy place. The young people are willing to send their children to be educated elsewhere, but do not wish to leave their own farmland.

Nibgee's people seem happy to mix with anyone who makes the effort to go down to see them or to celebrate their annual religious festivities. These regular pilgrimages supplement their income, yet they appear to resent outsiders forcing them to assist with outsider-instigated development initiatives.

\section{Main issues/ themes}

The main aim of this research is to discover how the citizens in the community of Nibgee regard their own development and whether they subjectively experience deprivation. Central to this self-perception is the way in which the Nibgee community perceives the rest of Ethiopia, and how they regard development. For the purposes of this research, local meanings of development will be used. In order to understand their current attitudes towards development, it is also important to discover how the Nibgee community perceived past development initiatives and find out why Nibgee village has apparently been unaffected by famine. Local prioritisation of basic infrastructures such as electricity, clinics, a school, and a road and access to clean water will be ascertained to confirm or disprove my hypothesis that they need a road. 


\section{Research questions}

\section{Primary questions}

- How does the community of Nibgee regard its own development? Do they subjectively experience deprivation of some sort, or are they happy as they are?

\section{Secondary questions}

- How does the Nibgee community rate itself compared to the rest of Ethiopia?

- How does the Nibgee community perceive past development initiatives?

- How does the Nibgee community rate the importance of transport integration and infrastructure linking the regions?

- Have they ever received aid?

\section{Structure of thesis}

Chapter two is the literature review, which comprises four major topics. The first examines modernization and transport and how transport economically, socially and culturally affects isolated rural communities. The second part of the chapter covers African states, elaborating on how African states and elites serve their own interests and forget the majority of the country dwellers. The relationship between civil society and the states is examined with historical and contemporary examples. The third defines participatory development and discusses its relevance in development. And the last discusses human error as the main cause of famine and assesses the role of the NGOs in Ethiopia before and after 1991.

The Ethiopian context for the research is further examined in Chapter Three with reference to history, politics, geography and religion. Chapter Four outlines the researcher's motivations and methods. It elaborates on why the research was undertaken, what methods were used, how the visit to Nibgee was organised and how, when and where the research itself was conducted. It discusses the physical, social and methodological barriers encountered, as well as the ethical considerations that were dealt with. Results are then presented in Chapter Five in sections delineated according to the initial research question and further divided according to the method used to obtain the information. These results are then discussed in detail in Chapters Six, to Nine, focusing in farm on transport, states, and famine. The final chapter then summarises the thesis with reference to the researcher's experiences and impressions during the visit to Nibgee, his reflection on the research process and findings and finishing with suggestions for future research. 


\section{Chapter 2}

\section{Literature Review}

\section{Introduction}

This chapter explores several issues surrounding development in isolated rural areas. It examines current theories regarding transport and development, African states and their responsibilities to vulnerable rural communities, the importance of participation in development, and famine - its causes and its impacts.

Transport has been dubbed a catalyst for development that paves the way for other forms of infrastructures. The first section of this chapter unravels the economic, social and cultural effects of roads on isolated communities. The second section of this chapter deals with how the majority of African states and their associate elites focus on taking care of their own interests and forget the majority of the country dwellers. The relationship between civil society and states is examined with historical and contemporary examples. The role of the NGOs in Ethiopia, before 1991 and after, will be discussed. Participatory development is defined, described and discussed in the third part of this chapter, and its relevance in development is discussed from every angle. Finally famine will be considered in the fourth part, and its causes and its effects discussed with particular emphasis on human error.

\section{Transport}

\section{The role of transport in development}

Regardless of which development paradigm is used, transport is recognized as being a fundamental precursor to social and economic development in rural communities (Njenga and Davis 2003:219). It has been noted that roads are often given priority over all other infrastructures, because they act as 'catalysts' to development Leinbach (1975:274), meaning that without any further effort, mobility itself drags all other networks into modernity (Hagerstrand 1987:274). Whether or not those infrastructures improve the quality of life of the rural population depends upon their "appropriateness to local conditions, including intensity of use, integration with local institutions and priorities, and 
the ability of the recipient country to maintain the new infrastructure, in terms of skills, equipment and other resources, and institutional will” (Simon 1996:60).

Without transport infrastructures, rural people have limited opportunities to buy and sell goods or access health, education or communication services, and are financially disadvantaged by the many difficulties inherent in immobility (McDonagh 2006:356). Even if they have raw materials such as cash crops to sell, their capacity to benefit from them is limited if they cannot transport produce to market. Roads would benefit them economically, by enabling faster, cheaper movement of goods as well as facilitating access to modern farming technologies. Socially, transport networks enable more frequent contact between social groups and permit the exchange of ideas. This ease of movement also benefits the government as they are able to expand their networks to protect, control and communicate with previously isolated and vulnerable groups (Heymann 1965:18). Therefore the effects of transport systems are not only confined to the movement of people and things but "[operate] within a physical, economic, social and political environment” (Nyasulu 2000:1).

\section{Transport and rural development}

"It is well known that many rural dwellers experience very limited mobility. It is also widely accepted that - as a generalisation - a high proportion of people in the rural areas of most Third World countries are poor” (Simon 1996:59). There are places where there is no alternative means of transport other than walking "whatever the distance involved and irrespective of the fact that goods may have to be carried" (Hilling 1996:157). Presumably Sub-Saharan African country-dwellers, like many of the poor, suffer from "inadequate access to markets and to basic social services” (Njenga and Davis 2003:235) and lack of exposure to modern ideas and farming methods which become necessary as growing populations put more stress on limited farmland (Boserup 1983:187). Therefore, linking isolated areas via improved transportation infrastructures - which has proven time and again, not only to reduce poverty, but to eradicate it quickly and effectively - could be expected to help poor rural African communities whether through facilitating trade or promoting “inter-regional migration” (Cervero 1990:126).

Transport arguably increases agricultural productivity and boosts the outputs that have traditionally been the only means of income production for poor farmers (Heymann 1965:18). Available technology determines agricultural production possibilities, but its 
usefulness is influenced by available knowledge as well as the ability of the people to marshal that knowledge and make actual use of it. Even where the technology is available, it is rarely accessible to the poorest farmers, which like many development initiatives results in a widening gap between rich and poor (Pottier 2003:3). As transport becomes easier and cheaper, poorer farmers can also begin to access both the modern technologies and the expertise to improve their own farming practices (Francisco and Routray 1992:911). This in turn stimulates improved agricultural production and marketing potentials. Hence, expanding transportation services increases income generating potential which leads to "surplus capital which can be expended on essential services” (Fouracre 2001:5).

Although the development of transport infrastructures may not automatically create successful modernisation (Hilling 1996), gradually and inevitably, roads enable access to other basic infrastructures. Once the rural transport infrastructure is set up, and provided the rural dwellers have access to adequate and affordable modes of transport (Nyasulu 2000:3), access to services such as health and education improves (Leinbach 1975:281), and farmers in isolated and remote areas can access modern technologies more easily. This has led supporters of modernization to argue that land mobility goes further than any other means of development to solve the age-old struggle of peasant farmers, breaking hindrances to inter-regional communication for rural communities (Wilson 1970; Fouracre 2001).

In contrast, isolation due to transport constraints can have several deleterious effects and side-effects on rural communities (Dnews 2002:1). In most Sub-Saharan countries, rural populations are disadvantaged due to difficult roads and insufficient transport that hinder access to fundamental services which would necessarily impact upon their health and social and educational opportunities (Dnews 2003:3). These "transport constraints on rural livelihoods are not simply a result of poor road conditions but are a culmination of inadequate infrastructure, ... remoteness and physical isolation from basic services” (Njenga and Davis 2003:219).

So, it is clear that transport and infrastructure development play a determining part in “ameliorating the conditions of rural populations” (McDonagh 2006:356). As Heymann (1965:18) states, "the movement of goods and people is hardly ever desired for its own sake; it is merely a means to serve other objectives". "Mobility is viewed in a positive light and connected with progress and growth” (Hagerstrand 1987:11) not only because it 
"provide[s] a more reliable form of haulage" (Leinbach 1975:273) but because of the flow-on effects.

\section{Transport and economic development}

Up to the 1970s, 'development' was regarded as being synonymous with 'economic development', measured by Gross National Product [GNP] per capita (Hilling 1996:14; Gillespie 2001:18). However, since then, this limiting focus on GNP and Gross Domestic Product (Bevan 1997:5) was expanded to include other aspects like socio-cultural, environmental and political aspects without denying the economic aspects (Gillespie 2001). These were recognised and measured using the Physical Quality of Life Index Technique (Francisco and Routray 1992; Edmonds), which comprises life expectancy, infant mortality and adult literacy (Simon 1996:7).

To ease the problems of Third World countries, the Keynesian products of the International Monitory Fund [IMF] and World Bank [WB] emerged to bridge the gap between the modernised world and developing countries - economically, socially, politically and culturally - by financing bankrupted sovereign states (Simon 1996:7; Kalb, Pansters et al. 2004:19). They did this by offering enormous amounts of credit to those developing countries that wanted to build up their transport networks, believing that mobility was the primary means of progress for developing nations (Benmaamar 2006). The high levels of investment committed to the transport sector in developing countries (Njenga and Davis 2003:220) suggest that it was seen as the key to progress. It enabled the marketing of crops, access to local employment, purchase of basic commodities, and access to social services, which balanced the economies in all sectors (Dnews 2006:1). Although there are many other components of economic progress, "transportation is a prerequisite of almost everything else that is needed to improve living conditions" (Cervero 1990:127).

The underlying premise of many "infrastructure projects" was that "transport was key to installing modern market institutions, to replace the traditional and often subsistence production systems” (Njenga and Davis 2003:221). The impact of modernisation would be to help traditionally immobilised nations make their rich raw material accessible to the market where they could sell it (Hagerstrand 1987:13). The faster the implementation of networks of mobility, the faster the development, and vice versa (Simon 1996:5). Therefore, budgeting for roads was advised to be prioritized higher than any other sectors 
including health, education or law-and-order (Benmaamar 2006:2), as these would follow automatically. Wilson (1970:44) stated that the establishment of the network of transport would effect economic advancement due to improved "political unity, social cohesion, economic growth, specialization and price stability as well as attitudinal change”; but the opposite was also possible. Despite its economic advantages, transport creates its own problems as it disrupts "the social resources upon which people draw in pursuit of livelihoods: networks, membership of groups, relationships or trust [and] access to wider institutions of society” (Fouracre 2001:3).

\section{Transport and social development}

The above economic objectives not only promote the economy but also influence social factors. As Fouracre (2001:4) describes, each person's response to the development challenge is also shaped by the society, culture and historical moment in which he or she lives. In analysing "society and culture we recognise that the behaviour of individuals is determined by structures and networks of social relationships and obligation and by shared knowledge and values" (Fouracre 2001:4). Moreover, "the more efficient diffusion of information must affect the modernization process” (Leinbach 1975:282). People living in isolated rural areas have often been disadvantaged by “social exclusion” (McDonagh 2006:356) mainly brought about by a lack of transport. One key and most obvious barrier is time, which, being equally accessible to all as a resource and a constraint, is saved by "physical mobility" (Hagerstrand 1987:13). Another barrier is lack of access to fundamental infrastructures. Therefore, the expansion of transport to rural communities has a great impact as it improves access to postal services, commercial banks, health centers, schools, and telephone exchanges. Undoubtedly, "the impact of the constructed linkages permitted new network growth in untapped areas” (Leinbach 1975:282).

Isolation can also have a protective effect which is reduced by increased mobility. The social impact of modernization is an agent of psychological intervention which a few have even deemed to be re-colonisation (McDonagh 2006). The social invasion of modernization is an observable fact about which few scholars argue. Improved transport infrastructure has the incidental effect of bringing about certain socially desirable patterns as well as other, less desirable patterns nicknamed MacDonalisation, Cocacolonisation (Pieterse 2000:177). The alteration of culture and the loss of traditional values call to mind the "momentum and pathos of decolonisation, [and] the arguments against cultural imperialism” (Pieterse 2000:177). Hilling (1996:15), however, mentioned the alternative, 
more Marxist perspective, in which "socio-economic transformation of the whole mode of production... [involved] the breakdown of colonialism, dependency and capitalism”. Marxist desire is different from Capitalist oriented growth. "Marxists seek growth to meet needs, as opposed to being motivated by private profit and competition” (Gillespie 2001:16).

Thus, the importance of transport to development is beyond doubt in regard to rural poor. It provides employment opportunities, easier access to markets and other services, creates networks of communication and trade and is a catalyst for the development of other infrastructures.

\section{African states}

\section{States in Africa}

Modernization strategies were introduced to Africa before the majority of African countries became independent. The colonial rulers set up basic urban infrastructures. The trend towards independence began in the late 50s; with the latest state, Eritrea, only becoming independent in 1993. In fact, many ethnic groups across Africa are still fighting for independence (Hameso 2004; Idris 2004; Robinson 2004). However, self-governance is not easy and those decolonized African nations, since gaining independence have, to varying degrees, faced many social, political and practical difficulties created by colonial powers. These include conflict over ethnicity, clans, culture and tradition, elitism, despotism, clashes over the control of resources and borders (Thomson 2004:8). However, as Nyerere said, the triumphant moment of independence was often marred as new initiatives were frustrated by an undereducated workforce: "Some of our countries had no trained people at all” (Nyerere 1998).

Along with railways and government buildings, Africa's departing colonizers left national boundaries, the demarcations of which were decided upon with little apparent regard to the ethnic, religious or cultural identities of the people, or to local politics or economy (Stedman and Lyons 2004:145). This is one of the many reasons that borders continue to be issues of bloody contention. Recent examples of the difficulties arising from arbitrary border demarcation were the horrific wars between the Tutsi and Hutu in Rwanda and Burundi, and the collapse of central government since 1991 in Somalia (Harvey 1997). Currently in Darfur, Sudan, neighbouring Chad and other Sub-Sahara African countries, 
there is fierce internal conflict which has killed, maimed and displaced millions. "From 1960 to 2000 there were 35 civil wars in Africa” (Stedman and Lyons 2004:141). Conflict and armed violence costs Africa around \$18 billion per year, “seriously derailing development” (Oxfam and Saferworld 2007).

False boundaries imposed by colonial powers have brought destruction to Africa. They jeopardized the sense of belonging and brought destitution, fear and war, including genocide. In fact, the colonial powers' creation of Africa's boundaries caused many of the problems that are happening in Africa today. Esteva (2001:10) argued that underdevelopment is a product of development. Somalia's suffering now, despite there being only one ethnic group and only one language but many clans (Harvey 1997:26) is the result of false boundaries. " Present-day Somalia has been drawn from what used to be known as British Somaliland, Italian Somalia, French Djibouti and the Ogden, which was subsequently abandoned by the British to Ethiopia" (Hand 1999:115). These different European powers separated the Somali people with out any consultation with that nation. Eventually the internal conflict there caused the collapse of central government, which created many warlords. Somalia has been a war zone since 1991 and currently fierce fighting in and around the capital city, Mogadishu, continues to force thousands to seek refuge in neighbouring countries ${ }^{13}$.

Just as there are many ethnicities and languages in Africa, there are also many social classes which were already in evidence pre-colonisation. The departing colonial rulers handed over power to select individuals or groups whom they thought would continue to promote their post-colonial interests.

Bearing in mind the diversity of the African nations, it is natural that each state pursues its own "unique ideology path to secure national unity and economic development" (Thomson 2004:37). The vast African continent contains almost all possible forms of government including monarchies, democracies, socialist states, and traditionally led groups. There is absolute monarchy in Swaziland, where power has been passed from father to son in a patriarchal tradition which even endured colonisation (Thomson 2004:93). Botswana and Mauritius are exemplars of African democracy and their economic growth has shown the benefits of pursuing this modernized way of development (Kalu 2001:53).

\footnotetext{
${ }^{13}$ BBC News
} 
On the other hand, Libya, Ethiopia, Angola, Mozambique and others followed the Socialist bloc for their development after power was taken through military coups. In Libya, Colonel Gadafi's military junta is enjoying the power for more than three decades under the umbrella of Socialism. The late president of Tanzania, Julius Nyerere, was dissatisfied with adopted forms of modernization and introduced African Socialism to his country. Unfortunately, no other countries followed his lead. Nyerere retired from politics in 1985 without any internal or external pressure (Walle 2001:152).

Even though most African countries modernized their outlooks through exposure to socialism, which aimed to break down social classes (Thomson 2004:83-5), the majority still adhere to some traditional concepts of class especially with regard to local monarchs or chiefs, established concepts of ethnic superiority or inferiority, matters of religion, voodooism and other traditional beliefs. As a result these unequal social strata are still apparent throughout Sub-Sahara Africa in consequence political and state issue always has priority and development left behind (Omari 1993:26).

\section{Era of African elites and the annihilation of development}

Disappointment followed hope as the first generation of independence fighters legitimatized themselves by officially adopting a traditional title. "Mobutu named himself Sese Seko Kuku Mgbendo Wazabanga 'the guide', Nyerere liked to be referred to as Mwalimu, the teacher” (Walle 2001:117). These aliases served to acknowledge their supremacy and absolute authoritarianism and the concept that "I am the state" (Kalu 2001:43). These old monarchies and rulers, who at least had the ideology of modernization, were overthrown and replaced by new and active military juntas, who captured power under the logo of nationalism.

The issue of nationality was also promoted and manipulated in the minds of the populace by the few who sought power and became another motivation to overthrow or abolish the previous rulers. International interventions during the Cold War era influenced and recruited the few elite or military juntas towards either capitalism or socialism and away from monarchy or the status quo (Udogu 2001:2). In the 1970s and 80s the concept of 'state' developed in different ways and several African countries became subject to pettydictators. Unfortunately, the new elite's and juntas' only aims were and are to extort tax, 
protect themselves, and promote their colleagues to ensure they will stay in power (Hameso 2004:169). Nyerere (1998) states that "Africa has more corrupt, tyrannical, and power-hungry elites, than have other continents either now or historically”. For example, Hailemariam of Ethiopia, Rowling of Ghana, Turre of Burkina Faso, Amine of Uganda, Berre of Somalia, Doe of Liberia and more (Harvey 1997:16). They controlled their nations by any and every means, including exiling, imprisoning or killing those who opposed them. In the 1970s and 80s coups or attempted coups d'etat and/ or one- man rule were common phenomena in Africa. Smith (2003:173) illustrated the occurrence of a coup d'etat or attempted coup every year in the 1980s in Third world countries. So, understandably, state leaders "seeking to maximize political stability rather than economic growth" (Walle 2001:24) tried to stay in power for as long as they could. They allowed their respective countries to be embezzled by their favoured friends, which created a few millionaires and a multitude of peasants and proletariats (Chabal and Daloz 1999:37).

The end of the Cold War left African states with little choice but to rely on western democracy (Nyerere 1998). In this era, the face of ambition for power changed from nationalist or socialist military juntas to rebels funded, sheltered and encouraged by the superpowers and neighbouring countries. These rebels were supported to overthrow the juntas and dictators who had evidently become as corrupt and dangerous as their predecessors. In Uganda, Museveni removed the brutal and tyrannous dictator, Idi Amin Dada; Zenawi in Ethiopia chased away Colonel Mengistu Haile Mariam; Afworki gained Eritrean independence from Ethiopia; and Kabila in the Democratic republic of Congo [DRC] ousted Mobuto Sese Seko (Ihnovbere 2001). Initially they were praised by superpowers who thought that "new opportunities had emerged to advance agendas of social justice, national liberation and democratisation locally and in the global system" (Robinson 2004:45). They hoped these reformers would bring economic advancement, good governance, accountability and transparency not only to their nation but to the whole of Africa. However, just as their predecessors had, they quickly became the dictators of the day. Even now, there is a "conspicuous absence of elite change" in the African continent (Chabal and Daloz 1999:32) and "most Africans are today no nearer being similar to North Americans than they were in the 1960s” (Chabal and Daloz 1999:46).

\section{African civil society now and its current leaders}

The gap between African states and the civil society has been observed to be ever widening. "In Contemporary Africa, the state is constituted to work against influence and 
interests of the people” (Ihnovbere 2001:67). When the civil society is suppressed down the embezzlements of public money because easier to achieve (Sandbrook 2000:53). Foreign power often publicly denounces the situation but the situation remains and trade with their countries. A case in point is America's trade with Nigeria during the brutal dictatorship of General Sani Abacha (Abegunrin 2006:240). As Daniel Arap Moi in Kenya, Mobutu Sese Seko in Zaire, M. Nguema in Equatorial Guinea, Paul Biya in Cameroon, General Ibrahim Babangida and Sani Abacha in Nigeria and Mohamad Sied Barre in Somalia have clearly demonstrated, civilian and military despots can "close political spaces, suffocate civil society, eliminate opponents, and squander scarce resources on building personality cults" (Ihnovbere 2001:61-2). "Warring parties target vulnerable groups and social systems and networks as part of their military strategies” (Harvey 1997:14) and leave little space for development for the majority of the SubSaharan African population living below poverty line.

The democratisation process in the Sub-Saharan countries is still far from free and fair. In Africa oppositions often boycott the elections (Sandbrook 2000:4-5). "Electoral victory may not always determine the legitimacy of the result, as vividly demonstrated by the recent experience of the Congo" (Chabal and Daloz 1999:151), Kenya and Chad ${ }^{14}$. In actual fact the power of the African's states run “ between Big men, or patrons, and their constituent communities” (Chabal and Daloz 1999:37). The common people of Africa often lead their life in poverty while the elite enjoy life with their people's wealth in the western world. The 2007 Transparency International [IT] index published how African states are, as usual, the most corrupt. This shows how Africa's few elite lead a comfortable life at the expense of rural villagers, whose lives worsen day after day. The needs and wants of the powerless are ignored. This is why participatory development has been recommended to give a voice to vulnerable.

Thus the literature on African states appears to suggest that there is often little common ground between political leaders [and their associated elites] and the rural poor. To the rural poor, states are often seen not as benevolent development agencies but rather as an institution that exploit resources and limits local control.

\footnotetext{
${ }^{14}$ bbcnews.com 05/02/08
} 


\section{Participation}

\section{Participatory Development}

The term 'participation' has been inseparable from development since it was mooted in 1973 by Robert McNamara, who was the President of the World Bank at that time (Ascroft and Masilela 1994:260). Since the 1980s, the "warmly persuasive" term 'participation' (Nelson and Wright 1995:2) has been used in the development process and was meant to change the previously prescriptive development area into a more userfriendly discipline (Ascroft and Masilela 1994:260). Initially hailed as a transformative influence (Mosse 2001:16) it was supposed to revolutionise the field of development. According to Hickey and Mohan this transformation did "not necessarily involve a reversal of the power relation but a strengthening of the bargaining power of the poor within these relations" (Hickey and Mohan 2004:14). It was intended to "bridge the knowledge and authority gaps between technocratic expertise and local involvement” (Gaventa 2004:33) and "enable women and marginalized people to determine choices in life and to influence the direction of change"' (Moser 1989: 1815, cited in Nelson and Wright 1995:1).

The effectiveness of participatory development theory however, has been challenged on many points and a few even accuse proponents of the theory of tyranny (Cooke and Kothari 2001:13). One such criticism is that the term participation has accumulated many meanings and even within a single organization, different people would have different ideas about what it means and would deploy it differently (Nelson and Wright 1995:1). Others claim that it merely perpetuates the top down approach by relying too heavily on institutional direction or is simply used to look good on paper but have little real world application (Ascroft and Masilela 1994:260). Even when it is agreed that participation should be "used to mean empowering the weakest and poorest, institutional procedures may work out in other ways” (Nelson and Wright 1995:1). However, the detractors of participatory development are forced to admit that it has undeniable merits such as "sharing knowledge and negotiating power relations" and challenging "structural ... oppressions and injustice within societies” (Cleaver 2001:13). 


\section{Participation}

'Participation', is a term used to describe an inclusive development rationale. According to Rahnema, participation "could be either transitive or intransitive; either moral, a moral or immoral; either forced or free; either manipulative or spontaneous” (Rahnema 2001:116). There is no a single technique, but an ever growing set of methods which enable "popular agency in relation to development" (Hickey and Mohan 2004:3). 'Participation' is the means by which disadvantaged groups are given the opportunity to influence "institutions and systems which govern their lives" (Burkey 1993:56). It is not only a bottom-up approach to development, but a bridge between ordinary people and institutions, and both must make a change (Gaventa 2004:25). Participation is also defined as "a framework for analysis" (Lane 1995:182). Therefore "Participatory development has an educative task as its first and foremost function” (Chetkov-Yanoov 1986: 40).

According to Chambers the purpose of participation should be (1997: 14) "learning how to learn, learning how to change and learning how to organize and act”. It seems easy to try and put forward the ideas and wish of the powerless, but "putting the first last is harder. For it means that those who are powerful have to step down, sit, listen, and learn from and empower those who are weak and last" (Chambers 1997:2).

\section{Development through Participation}

The term 'Development' simply means "good change” (Chambers 1997:xiv) and promoting "well-being for all" (Chambers 1997:9). Development was traditionally imposed on the powerless by the powerful (Anacleti 2002:168). But "the broad aim of participatory development is to increase the involvement of socially and economically marginalised people in decision-making over their own lives” (Guijt and Shah 1998:1). Participatory development was intended simply to ensure that the insiders or the beneficiaries of development initiatives were given the opportunity, the ability and the power to voice their own opinions (Crawley 1998:25; Gaventa 2004:25). McNamara summed up the importance of the participatory approach to development by explaining that "No program ... will help small farmers if it is designed by those who have no knowledge of their problems and operated by those who have no interest in their future" (Ascroft 1994:248). This claim was supported by a study by Cohen and Uphoff (1977, cited in Burkey 1993: 56), which found participation in project design was critical to the success of projects intended to help farmers. Rural people have their own concept of development and have always been engaged in some kinds of exchange of material goods 
and ideas with the outside. This already gives them a perception of the merits and demerits

of such exchange. Such "perceptions do not depend on how the world perceives and defines the concepts - but instead on how those concepts actually affect them" (Anacleti 2002: 68).

\section{Criticisms of participatory development}

There are pros and cons to every story, including participatory development. Initially hailed as a transformative influence (Mosse 2001:16) it was supposed to revolutionise the field of development. Powerless people were to be empowered and enabled to make decisions for their benefit and the voiceless given a voice to influence institutions such as NGOs and the government (Gaventa 2004:39). However, Mosse (2005:36) explains how participatory development as a goal or strategy remains ambiguous in order to maintain consensus or mutual agreement. Let alone the outsider, who can easily be identified, villagers themselves are not homogenous and even their own chiefs, as the key players, “excluded minority groups” (Mopati and Prinsen 2002:92). Traditionally favoured upper classes may intentionally or unintentionally exclude minority or less powerful groups, who may not feel confident to voice their real opinions whether they are included or not (Mosse 2005:36). In such circumstance it would be hard to imagine that Participation could successfully infiltrate the rural society or accurately diagnose the problem of poverty. Pottier (2003:3) argue development "exacerbated rather than reduced inequalities”.

People's attitudes are pivotal in determining the success or failure of development initiatives (Spencer 2004). Participatory development is often discussed by the scholars as a method which will create a common ground for both the development facilitator and the host community. "Local knowledge shaped both by locally dominant group and by the project interests” (Mosse 2001:21). Furthermore Mosse (2001) stressed no matter what strategy created to bridge the gap between insider and outsider on the participatory procedure, it is obvious that 'planning knowledge' outweighs 'people knowledge'. Rural people are reticent, especially to outsiders. "It is not often that rural people will express themselves [so] candidly” (Anacleti 2002:171). On the other hand David Turton, (cited in Spencer 2004:207) mentions that being a good talker inspires respect in Southern Ethiopian communities and “cultivating your reputation” is indispensable rather than sitting and observing. 


\section{Counter-criticisms}

Participation must be more than a policy statement - "there must be a genuine commitment to encourage participation in all aspects and at all levels of development work.” (Burkey 1993:57). Many development practitioners missed the core motive that participatory development “is well-being for all” (Chambers 1997:9). In fact Chambers (1995:34) advised those scholars or researchers to "hand over the stick, sit down, listen and themselves learn”. Furthermore he explained how the weakness of participation occurs because of the way in which they conduct the survey, not because of the participatory tools [PRA or RRA].

Therefore, participatory development suggests strongly that the rural poor must 'own' their own development. It is they who must define their development objectives and means. Thus approach seems to run counter to what most African states - and Ethiopiahad followed in practice.

\section{Famine}

"Famines are more weakly linked with food availability than had been supposed, and ... producing more food will not prevent famine unless poor people can obtain the food. What matters is not so much how much food is produced but who produces it, where it is produced and who can command it once it has been produced” (Chambers 1997:47).

\section{What is famine?}

Before addressing the issue of famine, it is important to understand what famine is. Bennett (1998:4) describes famine as a "severe shortage of food" in which "large numbers of people do not get the food they need to stay fit and well [and] become weak and may eventually die of starvation or disease”. Famine may be seen as the regional failure of food production or distribution systems, and an inability to purchase food, leading to sharply increased mortality due to starvation and associated diseases (Howe and Devereux 2004). Famine is simply when human beings' bodies eat themselves for survival (Mariam 1986:8), causing “mass death by starvation” (Devereux and Tiba 2007:144). However, distinct from the reality of starvation inherent in famine, are the underlying causes. Devereux (2007:3-13) differentiates between traditional, natural causes and modern, human-induced causes; coining the phrases ‘old famine' and 'new famine'. The causes of 'old famine' were natural calamities such as droughts, earthquakes, floods, tornados, and 
tsunamis. These inexorable and drastic natural events, which took many lives in past centuries, still occur. However, experts also now acknowledge the effects of lack of democracy; internal conflict; leverage by powerful countries; the limitations of international safety nets; and diseases like HIV/ AIDS (Devereux 2007:3-13; Waal 2007) on famine creation .

\section{Human actions and famine}

Democracy is not only designed to encourage human social freedom, but is also a means of giving opportunity to the people. In recent history, those countries which have succumbed to famine were often under the governance of dictatorships (Devereux 2007:5), which did not prioritise basic needs, such as food. A glaring example of this was when Ethiopia's military dictator government, celebrating the tenth anniversary of its power in 1984, spent two hundred million dollars on celebrations while thousands of Ethiopian’ farmers were dying of hunger (Frandin 1986 :6; Milas and Latif 2000:366). Lappe and Collins (1986:4) explain that famine is not based on scarcity of food or land; rather it is the scarcity of democracy.

Edkins (2007) argues that famine is the result of human error, and that the leaders of famine-affected countries should be brought to justice, as mass starvation is an offence against humanity. Many blame the heads of government or the democratic process of the country for causing famine through lack of awareness and preparedness (Devereux and Tiba 2007: 163). This point of view is supported by Devereux (2007) who more specifically lays the blame at the feet of one-party or dictatorial states for their famine histories. The shameful nature of the military regime of Ethiopia was widely criticised when, without the government's awareness, the whole world watched on the BBC how the famine of the 1980s affected the country (Hancock 1985:72-78; Bennett 1998:19).

Population growth has a direct positive relationship with need for food consumption (Dyson 1996). Simply put, the more mouths there are to feed, the more food you need to feed them. Hence, population growth has been linked to famine. This relationship was recognized by Thomas Malthus as early as the 1700s, and Neo-Malthusians since the 1960s (Young 2005). Even if the relationship between population and food production today differs from that of the 18th century; still, Neo-Malthusians point out the greater incidence of famine in densely populated areas than in less populated areas in underdeveloped countries. Furthermore the definition of famine may be somewhat subjective 
depending on the usual diet and local concept of destitution. For example, the amount of nutrition that may seem adequate to a family in China may seem inadequate to a similar family in Europe (Project 1985) this explains how the most populated countries have sometimes remained mysteriously famine free.

Economists as well as anti-Malthusians argue that population increase is not a major contributor to famine as it also increases the number of skilled workers who can use their skills to produce more food (Dyson 1996). This is why Europe and South Asia, despite their high density populations, have largely avoided famine in recent history (The Hunger Project 1985:25). Especially for rural dwellers in developing countries, in whose communities having children is highly valued for practical, traditional or religious reasons, population pressure on resources is common (Milas and Latif 2000). In Ethiopia, where children are considered a great gift from God, the majority of people consider using contraception as a sin (Pankhurst 1992). Children form an important part of the labour force on farms and serve as security for their parents’ old age (Project 1985). The United Nations Population Fund [UNFPA] has disclosed in their report (Dnews 2006) that the Ethiopian population has reached 70.7 million, which is the second largest in Africa, following Nigeria. The report revealed that the Ethiopian population is projected to reach 171 million after 47 years, with the average population growth remaining at 2.5 percent until $2005^{15}$. Furthermore, scholars agree that there was plenty of food in the world while millions died of hunger in the 1970s and 80s (DeRose and Millman 1998). They expanded upon this idea by stating how China and India suffered from famine in the 19th century and before, but today they have largely overcome the problem in spite of their enormous populations (The Hunger Project 1985:388).

In many developing countries, HIV/AIDS is both a cause and a consequence of food insecurity. Through employing livelihood-based approach, HIV/ AIDS infections can be seen to translate into a direct shock to household livelihoods and food security through reducing available labour, increasing expenditure requirements, reducing income and leaving behind those who are powerless to work such as the old and children. Waal (2007) clearly stated that "New variant famine" is complicated by the process of emotional, physical and economic rehabilitation from the household level to the national level. This problem is now reaching epidemic proportions in Sub-Sahara African countries further imperilling already vulnerable communities (Devereux and Tiba 2007:167-171). Shortages of food are exacerbated by the loss of the household breadwinners. Once the

${ }^{15}$ http://www.unfpa.org/parliamentarians/documents/IPCIpaperBrown.doc 1/10/07 
foundations of the family unit are shaken by the loss of too many of the working generation, the whole fabric of society unravels and recovery is slow if not impossible.

Hunger is one of the consequences of war at a household, regional and national level. "War also meant that a large portion of the male population was engaged in killing rather than in saving life” (Frandin 1986:6). Like HIV/AIDS, war kills or maims able-bodied people who may otherwise be producing food. Armies always increase in size during times of war, which takes away the bread-winning peasants, leaving old men, women and children who, especially in rural areas, become vulnerable to any other factors of famine (Currey and Hugo 1984; Messer 1998). War destabilises economies and forces the price of necessities to extortionate levels meaning that people may even sell the very things they need for long-term economic recovery to get instant cash to survive (Kumar 1987).

Wars, droughts and disease epidemics are common occurrences in Africa, often disrupting food production (Adedeji 1989:15). Those who suffer most at such times are the rural dwellers. These African farmers, their lifestyles and production systems have historically been misunderstood, misrepresented and marginalized by their governments (Haile, Tsegaye et al. 2004:1) and local knowledge, shaped by generations of experience and adaptation to their environment (Spencer 2004:209) is usually ignored. Nyasulu (2000:2) warns that governments should consider the far-reaching effects of laws - especially tax and import laws - at the grass-roots level. They must consider whether taxes and technologies that can boost productivity or mobility are affordable to the farmers. Otherwise their policies could have the undesirable effect of crippling their countries' food production systems.

When broken into its simplest components, food production can be said to rely on the availability of: fertile land, labour, technology, seeds or stock and suitable weather. Fertile land is either there already, or it needs to get made through fertilising, manuring and building up the topsoil; but, in any case, it needs to be maintained. Ecological sustainability therefore is of paramount importance. Generally people who have lived on and farmed the same land for generations have a good idea of what can or cannot be done on their land. Traditional farming practices have had to be sustainable by necessity and have a proven track record of success. Therefore locals often feel that they know the best way to farm their own land and resent newfangled and potentially expensive or risky notions imposed on them by developers (Spencer 2004:211). 
While the birth to death ratio maintains a sustainable balance (Watkins and Walle 1983:28). Poor people often prefer to stick with their own tried and true production methods that carry "less risk of debt and dependence" (Chambers 1995:21). However, as growing populations place heavier demands on limited land resources, increasing production capacity becomes desirable. At this point it is imperative that development, and especially any radical change in land use, is done carefully and with much crosschecking of data from various sources. It is too easy to try and graft systems of farming that have worked in different settings onto new ecosystems in their entirety but this has potentially disastrous ecological, economic and social consequences (Dyson 1996). This is why Chambers (1997:14) stressed the importance of attending to local experts and seeking their advice throughout the development process.

This exchange of ideas and knowledge must go both ways (Gaventa 2004:33). Even the usefulness of new technology is limited by available knowledge as well as the ability of the people to marshal that knowledge and to make actual use of it. As Fouracre (2001:4) says, “Each person's response to the development challenge is also shaped by the society, culture and historical moment in which he or she lives”. When they feel the need for change the momentum for development will come from them. As people take ownership of the development process, "their interests, values and aspirations necessarily determine the content, strategies and modalities of such development” (Adedeji 2006). But if technologies are unreachable (Nyasulu 2000:3), unaffordable (Francisco and Routray 1992:11) or unworkable (Leinbach 1975:282) they may as well not exist for the poor rural dwellers.

According to Haile, Tsegaye and Teka (2004:1), ecological disasters in Sub-Saharan Africa have become more common since the 1970s. They state that poor rural dwellers are particularly vulnerable to recurrent drought, famine, land degradation and socioeconomic crises by which their standards of living are seriously affected. Haile et al go on to say that the resultant food shortages requiring food aid have become common occurrences in the region. As previously mentioned, if farmers are removed from the farms by war, resettlement, disease or poverty, they cannot grow the food. If their soil quality is degraded, there is too much or too little rain or insufficient seed crops or farming technology, they cannot grow food. When population outstrips production capacity there is famine. Although production is not the only factor affecting famine - availability and affordability also having their impacts (Chambers 1997:47) - it is one of the prerequisites 
of self-sufficiency. Therefore it is important to have early warning systems to enable survival if not prosperity through hard times (Braun, Teklu et al. 1998:129-130).

In summary, then, famine and food shortage has been a frequent occurrence in Africa. Whilst drought and disease have contributed, it has been human factors [state policies, war, and population growth] that have been critical in upsetting the integrity of existing food production systems.

\section{Conclusion}

This literature review started with a discussion of the importance of transport to isolated rural communities. In the second part, African states and their responsibility to civil society was examined including how the elite minority manipulate and rule the poor majority of the nations discussed. The third part dealt with participatory development and its relevance to vulnerable or marginalised communities was assessed. The causes of famine were discussed with particular emphasis on human error. This literature, then, gives some back ground for the study of Nibgee providing some suggestions to explain the current situation, though much remains unanswered as yet. The next chapter will briefly outline the Ethiopian context. 


\section{Chapter 3}

\section{Ethiopian Context}

\section{Introduction}

The Ethiopian population is estimated at approximately eighty million. Over eighty-five percent of the Ethiopian population lives in rural areas, and the farming sector is the backbone of the country's economy. Bearing this in mind, it would seem logical that Ethiopian governments would have done their best to support and foster the development of this important sector of the community. The truth, however, falls sadly short of the ideal. Under imperial rule, successive monarchs left rural peasants to the mercy of feudal landlords. Traditionally, although the peasants were responsible for all the labour and input, they were only permitted to keep a small percentage of their produce, while the rest went to the landlords. The communist revolution, which was expected to have been an ideal vehicle to bring 'power to the people' and more equal distribution of resources, instead left poor farmers without any basic and fundamental farming supplies at all, while still imposing rigid taxes and fixed crop prices. Successive governments, although democratically elected, have failed to privatise properties confiscated by the previous military regimes and have not managed not control the inflation which has made the farmers' lives more difficult. Taxation remains the only form of contact between the common rural dweller and the government; and development or services are not forthcoming.

Many would-be colonizers attempted but failed to take Ethiopia but, notwithstanding a brief occupation by Italy, it has remained uncolonized. Ethiopia was a member state of the League of Nations and a founding member of the United Nations; the establisher and organizer of the African Organization of Unity and the headquarters for both the African Union and the Economic Commission of Africa. Many scholars have written on the diversity of cultures and languages in Ethiopia, although time has made this once proud and wealthy nation of warriors into the poorest of the poor.

Ethiopia is situated in the northern hemisphere just above the equatorial line and lies entirely within the tropics, between latitudes 3 and 18 degrees North and between meridians 33 and 48 degrees East (Westphal 1974:10). It is bordered on the north and north-east by Eritrea, by Kenya on the south, Djibouti on the east, Somalia to the west and 
Sudan to the south-west. The country's $1,127,127 \mathrm{~km}^{2}$ area has many high plateaus and is between 1,500 and 3,000 above sea level. Traditionally in Ethiopia there are three "agroclimatic zones called Dega ${ }^{16}$ at altitudes of over 2,600 masl 'meters above sea level', Woina Dega ${ }^{17}$ at altitudes between 1,500 and 2,600 masl and Kolla ${ }^{18}$ in the lowlands below 1,500 masl” (Waktola 1999:VI). At all of these levels, although the crops differ, the farming techniques are similar and have remained unchanged since prehistory.

\section{Religion}

Originally, Ethiopia was called Abyssinia. Ethiopia is mentioned in the Bible in more than 41 places in both Old and New Testament (Strong:312). "Second only to Japan and Iran, Ethiopia can trace its direct lineage to the beginning of the Christian era” (Jesman 1963:1). The name of Ethiopia is also in the Koran - the Muslim doctrinal text. The Prophet Mohamed's best friend and co-worker was Bilal Ibn Rabah, an Ethiopian slave born in Mecca in the late $6^{\text {th }}$ century, who officiated as a muezzin ${ }^{19}$ of the Islamic faith. Today Ethiopia is 52\% Coptic Orthodox Christian and 40\% Muslim with a smattering of local traditional religions and other Christian denominations. Religion has been an ongoing source of conflict in Ethiopia but the Coptic Orthodox majority has maintained its supremacy even over the calendar and its numerous Christian holidays. All the monarchs of Ethiopia have been Coptic Orthodox. Described as an island of Christianity in sea of Islam, Ethiopia has endured countless wars with the surrounding Arab countries (Thomson 1975:8-9). Even the war with Somalia at the moment could be attributed to this religious variance. Despite this, Ethiopia is a secular country and there is in fact little illfeeling between Ethiopian Muslims and Ethiopian Christians. Since the Communist revolution in 1974, some Muslim holidays have even been added to the Ethiopian calendar.

In the early $19^{\text {th }}$ century, Ethiopia was the only black nation whose representatives participated equally with other foreign dignitaries in international forums. Emperor Haile Selassi I was a respected king among the kings, queens and leaders of Europe. He frankly addressed the suffering of blacks in the world, which made him a well known figure to all black nations. Whenever he got a chance to meet black communities he offered them an open invitation to Ethiopia, where there was no racial problem. This, in addition to the

\footnotetext{
${ }^{16}$ Highland

${ }^{17}$ Intermediate altitude

${ }^{18}$ Lowland

${ }^{19}$ One who calls people to prayer.
} 
aforementioned religious background, made Ethiopia a holy ground for several including Rastafarian groups.

One of the minority religions in Ethiopia is Rastafarianism. A small population of foreign Rastafarians live in a place called Shashemane, $250 \mathrm{~km}$ away from the Ethiopian capital, Addis Ababa, which was granted to them by the late Emperor Haile Selassi I. The word 'Ras' is the Ethiopian title for 'chief' (Leslau 1992:42) and Tafari was the real name of Emperor Haile Selassi prior to his coronation. When Ethiopia became a member state of the League of Nations in 1923, the Emperor was known by this name (Greenfield 1965:157). The name, Tafari was picked up and intertwined with the religion of Christianity during that era and Ras Tafari became the voice of black suffering, which exalted him to Messianic status in the eyes of many black people. People of African descent in the Caribbean, especially, believed that Ras Tafari was a divine leader sent by God, and they revered Ethiopia as a holy place. However, this concept of the Emperor's divinity was foreign to the majority of Ethiopians and they still do not believe in it. In fact, Haile Selassi granting free land to foreigners while doing little for his vulnerable farmers may have created some resentment against him.

\section{Modernization to 1913}

Rulership of the Ethiopian kingdom passed from generation to generation until 1974 when the ancient dynasty was ended by a communist-inspired coup. Throughout this imperial time period, Ethiopia did not lock its gates to foreigners, the first Portuguese embassy arriving in 1520 (Markham 1869:14). However, even earlier than this, the Bible and the Koran are evidence that Ethiopians also traditionally travelled to visit, explore and trade internationally.

Modern diplomatic relationships with Ethiopia were established by the superpowers after the victorious war with Italy. Menelik's victory over the Italians turned triumphant Ethiopia "into the champion for a liberated black Africa, into a 'beacon of independence and dignity'” (Strecker 1994:303). The battle in Adowa, and the defeat of the Italians on March 1, 1896 (Greenfield 1965:123) strengthened the power of the Ethiopian government and was a stepping stone to diplomatic relationships with major powerful countries. France, Turkey, Russia, Britain and, of course, Italy, paid respect to the court of Emperor Menelik II in Addis Ababa (Greenfield 1965-6). "Menelik’s Swiss-born adviser, Alfred Ilg, ... stayed with the emperor for twenty-seven years” (Strecker 1994:208). These 
international connections facilitated the quick introduction of modern technology.

Modern infrastructure was put in place with the development of the first national currency, telegraph, the construction of the Djibouti to Addis Ababa railway [the only rail way up to now] and the earliest modern roads and bridges hotel, school and the beginnings of cabinet government and, in 1890, telephone. Until the time of Menelik II, all the other monarchs, main aims seemed to be to get armaments to crush internal or international opponents, but still nothing was done to support or develop the farming sector. According to Pankhurst (1967:185-6) it was at this time that Russia sent doctors through the Red Cross Society. Addis Ababa was established in 1887, and in 1897 water supply to the palace was set up with the help of hired technicians from Switzerland.

\section{Ethiopia from 1913 - 1974}

Even though Ethiopia started its era of modernization just before the twentieth century, during the regime of Menelik II, it was not until the late Emperor Haile Selassi I succeeded to the throne in 1930, that most diplomatic agreements were signed by the government and the embassies of most countries opened their councils to Ethiopia. Haile Selassie I came to the throne following the death of King Menelik II's daughter as a descendent of King Solomon. Ethiopian king, Menelik I, was reputedly the son of King Solomon of Israel and queen Sheba of Ethiopia (Beckingham and Huntingford 1954:68). He supposedly brought the original Ark of The Covenant of Moses as a gift from his father, which most Ethiopians still claim is still there (Raffaele 2007 ).

In 1931 Ethiopia introduced its first modern constitution which was amended in 1955, to commemorate the twenty-fifth anniversary of Haile Selassie's coronation, and in 1974, which led to the crown being disestablished (Gilkes 1975:63). Law and order was reinforced and Ethiopia became more united under the rule of Emperor Haile Selassi despite the Eritrean separatist movement to gain independence from Ethiopia, eventually happened in 1993.

\section{Italian Invasion}

It was in Haile Selassi I's time that Italy invaded Ethiopia for the second time. He fled to the United Kingdom and Italy succeeded in controlling Ethiopia between 1935 and 1941. For most of those years Haile Selassie was in London canvassing public support and 
asking the members of the League of Nations, of which both countries were members, to intervene (MacGregor-Hastie 1963; Morgan 2004). The exile helped him to expose the situation to the members of the League of Nations as he sought support to oust the Italians. At the time of the exile many news articles publicised the sadness of the situation for the person who was called King of kings and the Lion of Judah. The Time Magazine wrote, under the title of 'Man of The Year': “In 1935 there was just one man who rose out of murky obscurity and carried his country with him up and up into brilliant focus before a

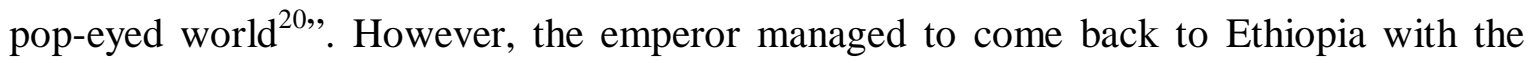
help of British forces, who ousted the Italians and returned the emperor to his throne.

Italian Fascist leader, Mussolini, had three reasons for attacking Ethiopia in the face of opposition and sanctions imposed by the League of Nations (Lyttelton 2002). The first motivating factor was the need to avenge the Italian defeat at the hands of Ethiopia in Adawa in 1880. Italy dwelt on this embarrassing defeat for 40 years and Mussolini used this national resentment to gain public support for retaliation (MacGregor-Hastie 1963). Even the Catholic church supported the Italian invasion of Ethiopia (Morgan 2004). The second reason for the Italian attack was to experiment with Blitzkrieg-like methods of forceful domination. Mussolini, who had an ambition to conquer the rest of Europe, wanted to test his army and armaments to refine his technique for swift and effective attack. He organised half a million solders, equipped with the latest technology including vehicles, aircraft, artillery, and mustard gas, to send against Ethiopia (Lyttelton 2002). The third and most pressing reason was economic. During the 1930s the world economy was struggling under the effects of the Great Depression. Italians, like the rest of the world had suffered from the stagnation of local and international markets and deflation. By arming, dressing, feeding and transporting his army, Mussolini created an instant market for goods, thereby aiding the recovery of the Italian economy (Morgan 2004).

Nibgee itself only faced one day of sustained attack at the hands of the Italians, in which many houses were burned. There were no casualties on Nibgee's side, however, and the Italians were discouraged by the difficult topography of the valley, and the effective guerrilla techniques employed by the Nibgee locals, and did not come back. Many insurgents from nearby also came to Nibgee to hide, and the treacherous cliffs saved them, too. There is an expression: you can do anything you like elsewhere and hide from the

${ }^{20}$ January 6, 1936 Time magazine 
outsiders in Nibgee provided the locals sympathise with you; but you cannot hide any wrongdoing committed in the village itself on pain of exile.

The atrocities of Italian envision damaged a lot of basic infrastructure. Emperor Haile Selassie I, carried on developing Ethiopia. The currency of Ethiopia was recognised throughout the world at the time of the Emperor. Diplomatic relations with the West were tight. In fact, the West "continued to back Selassie, who they regarded as a bulwark against 'communism' in Africa” (Steven 2006). However, the development contributed minimal progress for the democratic practice Rahmato and Ayenew (2006:50) and left the peasants to die in silence.

\section{Military rule $1974-1991$}

Emperor Haile Selassie I was a popular monarch, well-known throughout the world. He tried to promote foreign investment and development initiatives. However there was growing dissatisfaction with his failure to pass power on to a younger ruler or to take steps to eliminate social inequalities which left the mainstream of the farming population as vulnerable as before. Consequently the crown was overthrown in 1974 by the military junta and in 1975, aged 83, Haile Selassie I was killed. The new military government or the Derg, adopted Marxist-Leninist policies and looked to the communist world for support rather than the West. It was the famine of 1973 that gave the opportunity for the military junta [Derg] to seize power the year following (Schmale 1993:201). The Derg adopted a radical approach, with the Land Reform Proclamation of March 1975 that nationalized all rural land, abolished tenancy, and put peasants in charge of the land. "From then on land was to be state property, with peasants enjoying usufruct right only" (Rahmato and Ayenew 2006:51).

The aim of nationalisation was to improve the quality of life for the majority of rural dwellers, who actually worked on the farms. However the land legislation never took into consideration the affordability of the ongoing input for the land. In fact the Derg completely disregarded the future effect of that legislation for the individual farming households. Soon thereafter the problem of food shortages arose. Denying the right to sell or lease land reduced the sense of ownership. The government tax impositions on top of the ongoing input, such as fertiliser and oxen, created dissatisfaction and real financial hardships (Mariam 1986). Famine took hold at an alarming rate and millions were displaced. The land enormously affects farmers in pastoral areas as they rely on it for 
feeding their herds and for their own survival (Devereux 2003:19).

When the Derg realised the migration of distraught farmers, they designed a resettlement strategy. "As a response to devastating famine and environmental shocks, the Derg embarked on a massive program of resettlement involving millions of peasants” (Rahmato and Ayenew 2006:51). These massive mobilisations created lots of ethnic tensions between those who resented having to leave their places and those whose local resources had been put under strain by the added extra mouths. Millions of farmers perished through disease or lack of food, but the Derg's response was to forcibly resettle as many as possible (Green 1995).

Many argue that the resettlement was a strategy to reduce the political turmoil of the north. Most people in Ethiopia were forced to move to designated areas where the communists could keep a close watch on every individual's activities in a 'divide and conquer' strategy. Furthermore, marketing policies had a huge effect on the development of small scale agriculture (Franzel and Houten 1992:212). The price of food grain was standardized, but the input required to farm, including taxation, increased year after year. This created an atmosphere of fear and repression which the country had never experienced before (Hancock 1985).

There was no constitution established by the Derg till 1987, after their demolition of the previous constitution in 1974 (Ashenafi 2003:31). No one had the right to object even if they were not happy about any of Derg's declarations. "Anger in the armed force was quickly turned into action” (Thomson 1975:71). Those who were suspected of dissatisfaction were imprisoned, tortured, and summarily executed on a massive scale under the logo of 'Red Terror' Ashenafi (2003:30). The expectations of the 85\% of the Ethiopian population who were farmers' were dashed as the land of those who could not afford to pay the tax was confiscated and redistributed along with all privately owned land (Holden and Yohannes 2001:1). Many became prisoners, which made life even worse for the majority of farmer's households (Mariam 1986).

Large businesses and extra houses were also nationalised under the 'Ethiopia Tikdem', or 'Ethiopia First' slogan. The new regime was not ideal, as the leaders of the coup fought each other, and Mengistu Haile Mariam ruthlessly set about eliminating his rivals (Thomson 1975:7-18). Taking advantage of internal unrest, Somalia invaded the Ogaden region in 1977 and occupied most of the third largest city of the country, Harar, before 
being forced back by a hastily conscripted peasant army (Parker 1995). In the north, the Eritrean People's liberation Front [EPLF], who had long campaigned for independence, began to step up its hostilities. This war proved more difficult than that with Somalia and, as the EPLF gained strength, the situation and the stagnation of development within Ethiopia worsened. Inhibition of development went beyond expected and in 1984 the drought affected hundreds of thousands (Lautze and Maxwell 2007). Since then, starvation has become the international stereotype of Ethiopia, with not hundreds or thousands, but millions affected by drought (Pankhurst 1992; Githinji and Mersha 2007). "The drought and famine which have swept East Africa destroyed Ethiopia's physical ability to sustain itself” (Schenk and Schenk 1987:7). Thus the new communist state became as bad as or even worse than the old empire had been, and development in Ethiopia stagnated or even went backwards the vulnerable farmers' situation was exacerbated further (Parker 1995).

\section{Famine and Ethiopia}

Famine has followed war throughout Ethiopian history. "The civil war for Eritrean independence, starting in 1962, was followed by the famine of $1972-1974$. This killed 200,000 people” (Parker 1995:60). This was a factor in creating the dissatisfaction with the Emperor that led to Emperor Haile Selassie being overthrown in 1974. The war with the Tigrayan People's Liberation Front [TPLF] started in 1975 and was followed by a territorial dispute with Somalia. The ongoing war against Somalia, Eritrea and rebels was a central factor in the 1984-5 famines, when the present Government's party was part of the anti-Ethiopia insurgency (Milas and Latif 2000). Even in the 1980s, when the famine was at its peak, the Ethiopian government was spending an estimated \$440 million a year on weapons. The military government of Ethiopia was unwilling to admit there was a famine. However, the BBC went there and exposed the whole story (Hancock 1985:73). At a national level, the Ethiopian government was exporting fruit to Europe for money to buy arms while Europe was sending food-aid to save Ethiopia's starving population. Food aid was reallocated to fighting forces, but did not seem to contribute to Ethiopia's longterm food security (Milas and Latif 2000).

Ethiopia and Eritrea were again at war from 1998 to 2000, during which time the Ethiopian government was spending millions on the military effort - money some Western diplomats say could have been put to better use (Milas and Latif 2000). Still, today, Ethiopia suffers from food shortages. The war between Ethiopia and Eritrea has been disparaged as a nonsense battle between two poor nations (Messer 1998:168) but it has 
had far reaching economic consequences as Ethiopia lost access to the Red Sea ports. Currently the Ethiopian troops are in Somalia and there is a buffer zone between the Ethiopian and Eritrean border. In recent times, it seems sure that the Ethiopia-Eritrean war may erupt again at any moment as they accused each other at UN general meeting in September 2007. In the opening session of the Ethiopian parliament in October 2007, President Woldyess requested that the budget for defence be increased, as the war with Eritrea was imminent ${ }^{21}$.

\section{The role of civil society $1974-1991$}

The period of military rule in Ethiopia was characterized by state control of the economy and brutal repression of political opposition. Three major wars were fought in this period during the war of independence with Eritrea, the civil war against the Ethiopian People's Revolutionary Democratic Front, and an international war against Somalia in 1977-78. During these times several bilateral, multilateral National Non-Governmental Organizations [NNGOs] and NGOs evolved to address the calamity of famine, but only under strict State control. Not only was their work under State control, but their staff's leisure time was also strictly supervised. They did not have a chance to say or do what they wanted. In this era, the role of NGOs remained mainly in the area of supplying emergency needs and service, not development work.

Ethiopia between 1974 and 1991 was a military dictatorship - the least conducive environment for co-operative NGO-state relations. Welfare provisioning and development work of NGOs were tolerated, so long as they did not challenge government policy openly. NGOs were, however, restricted from operating in regions experiencing civil unrest or warfare. In part, this tolerance stemmed from the lack of development resources from official donors. MSF [France], a humanitarian NGO, was expelled in 1985 in response to their criticism of the government's resettlement policy and the independence struggle (Bratton 1989). During these times the government did not allow the NGOs to act in positions of advocacy, as they were treated as the agents of the West. Some NGOs were forced to make a choice between working either with the government, or with the opposition.

For the state, intent on achieving a top-down transition to socialism, there was little perceived benefit in learning from participatory or bottom- up approaches to development.

${ }^{21}$ VOA Amharic service on [8/10/07] 
There was little alternative for NGOs, but to operate through state structures at a local level, and although some NGOs did support regional ministry staff with resources and training, co-operation remained limited (Jones 1992:85). The state's institutional arrangements relating to NGOs focused very much on control. Each NGO was required to register with the Relief and Rehabilitation Commission [RRC], and the project then had to be cleared with the relevant line ministry. These mechanisms were used to restrict NGO operations (Borton 1995:35).

\section{Ethiopia since 1991}

Weakened by the collapse of communism in the Soviet Union, the widely unpopular Derg was overthrown in 1991 by the Ethiopian People's Revolutionary Democratic Front [EPRDF], comprising opposition groups drawn mostly from the northern province of Tigray. Under pressure from western nations to liberalize the economy, current government policy is to promote a free market and to create a federal state, a process which threatens to unleash a rising tide of ethnic unrest (Schmale 1993:204). With a nationwide economic focus on gaining as much foreign currency as possible through exports, local life became more difficult as inflation caused the price of even basic goods to rise unbearably.

A Transitional Government was formed by the Ethiopian Peoples' Democratic Revolutionary Front [EPDRF] which consisted of several liberation movements, such as the Tigray's People's Liberation Front [TPLF] and the Oromo Liberation Front [OLF]. The collapse of the Derg regime was expected to end the era of Ethiopian poverty. Every front organized them to alleviate the problem of the peasants of their respective ethnic group. For example, instead of learning Amharic ${ }^{22}$ in school, children from the main linguistic groups - and there are over 95 distinct languages spoken in the country - will be taught in their own ethnic tongue. ${ }^{23}$ This may help to preserve cultural diversity and to foster regional autonomy but it will almost certainly make the task of political unity even harder to achieve. The style of extortion on peasants' life changed its face and those who did not support the agendas of the government, their land have been taken allegedly on redistribution mechanism.

\footnotetext{
${ }^{22}$ The national language and the only sub-Saharan African written language.

${ }^{23}$ The other ethic groups thought that they were mistreated by the Amhara ethnic group. Ethiopia was not colonialized by foreigner. Therefore they do not blame the west rather the Amhara ethnic group.
} 
The population of Ethiopia is growing rapidly through natural increase and urban-rural migration-from about 45 million in 1984 including Eritrea to more than 75 million today without Eritrea. Such rapid growth of population outstripped the capacity of the farming land. Ethiopia also has a lack of both technology and manpower. Hence, widespread famine has persisted to the present day despite international as well as national NGOs existing for more than four decades in the country; the number increasing from 60 in the 1970s to more than 500 today. Nevertheless, the Ethiopian government has begun an enormous campaign since the celebration of Ethiopian's Millennium ${ }^{24}$ to change or to eliminate the stigma of Ethiopia’s image (News 2007).

\section{Role of NGOs after 1991}

During the transitional time when the socialist regime was being overthrown, the Transitional Government embarked on a process of political and economic liberalization, including a regionalisation policy. They wrote a new constitution and set the stage for multi-party regional and national elections. In the national elections held in May 1995, which ended the transitional period, the Federal Democratic Republic of Ethiopia was established [Africa Confidential 1995:4] The main focus was to rehabilitate the dismantled military. Operational NGOs in Ethiopia have proliferated since 1991. According to the Relief and Rehabilitation Commission the number of registered NGO has grown from 60 to more than $300 .^{25}$

The increase in political space for civil society institutions in Ethiopia eased relations between the state and NGOs. There was little danger of any registered NGO being expelled or banned. The new political and developmental direction of the Ethiopian government also suggested that relations between the state and NGOs would improve radically. As well as promoting a more liberal political and economic environment, the development philosophy of the new regime was more in tune with NGO approaches, including a focus on grassroots participation. Therefore the potential for scaling-up NGO activities was more favourable. The relationship between the government and NGOs did not last well. At the time of Ethiopian and Eritrean war, all NGOs advised both countries not to go to war as millions of their people were starving. However, the NGOs, the West and the UN's continued advice was ignored. Once again, the two nations became engaged in war and spent millions of dollars a day for about two months, causing the development

\footnotetext{
${ }^{24}$ Millennium of Ethiopia was celebrated on 12 of September 2007.

${ }^{25}$ Personal communication with the friend and government official September 2003 
of both countries to become chaotic. The issue that led the two countries into war has not yet been resolved and some predict they will again engage in war the near future. ${ }^{26}$

Aid givers sometimes come with their own hidden agendas (The Hunger Project 1985). Some NGOs, who were working in the country, were Christian oriented; however, the host did not welcome them. According to the locals, these NGOs were propagating their own denominations of Christianity, which brought unwanted problems as Coptic Orthodox Christians and other Christian denominations have huge theological differences. For this reason, locals resisted NGOs that were considered to be agents to preach to them, or influence them to believe in another form of Christianity. Thus, the Ethiopians, in the northern and central parts of Ethiopia were and still are not often willing to accept any advice from NGOs. ${ }^{27}$ Some NGOs also, are not happy to work with them.

\section{Conclusion}

This chapter has briefly examinee the history of Ethiopia, where it is situated and how it, unlike other African nations, has managed to remain independent despite the efforts of would-be colonizers over the centuries. It is a history that has revealed times of severe stress for ordinary people, whether through famine, warfare or exploitation by the state. Nibgee has been touched by all these events.

\footnotetext{
${ }^{26}$ http://www.reliefweb.int/w/rwb.nsf/6686f45896f15dbc852567ae00530132/bace6c87b096ab68c1256dc100569ece?OpenDocument ${ }^{27}$ BBC news Thursday, 2 January, 2003, 17:56 GMT Christian groups clash in Ethiopia
} 


\section{Chapter 4}

\section{Methodology}

\section{Introduction}

The researcher was born and raised in Ethiopia, and has travelled extensively throughout the country on numerous occasions. As an employee of a tour and travel agency, the researcher had ample opportunity to observe many diverse communities and ethnic groups in Ethiopia. The motivation for this research arose following a brief visit to the Nibgee community in 2005, and the unexpected responses of the people he met to his questions about development. The researcher's understanding of local culture gave him an advantage when it came to gaining the trust of this isolated community.

\section{Relationship with the community}

The researcher is of the same ethnic group as the Nibgee villagers and speaks the same language, Amharic ${ }^{28}$. He first went to Nibgee, as did many other visitors, to celebrate the festival at Shifudge Gabriel Church. This festival was initially an annual event, but it has since been made a biennial festival due to pressure from outsiders. The locals traditionally respected both dates already. Like many of their holy days, the day of Gabriel, which falls on the $19^{\text {th }}$, is respected with a holiday every month in Nibgee but was traditionally only celebrated with a feast in the fourth month of the Ethiopian calendar 'Tahessas" ${ }^{29}$. Visitors to the church are welcomed as guests but are never accepted as locals are. Although most of the expensive food and other necessities for the festival of St Gabriel are provided by the outsiders, the locals give them a lot of free help and some ingredients for cooking and local alcohol.

Their isolated geographical situation and the social unity of the community, gives Nibgeeans a strong sense of separate identity. Anyone who comes into Nibgee is considered to be an outsider. In this monocultural and highly religious society, verbal and even physical crudity is common when they encounter an Ethiopian from a different denomination. For them even a Muslim would be more welcome than an Ethiopians from a denomination other than Coptic Orthodox. Hence, gaining acceptance was a real

\footnotetext{
${ }^{28}$ The official written and spoken language of Ethiopia.

${ }^{29}$ In Ethiopia, the year starts in September; therefore 'Tahessas' is December.
} 
challenge for the researcher. Let alone a researcher whom they do not know, the valley dwellers of Nibgee consider any people who live up the hill to be outsiders because of their lifestyle differences. One man, who had lived there since he was nine years old was still not accepted and was not given any land to farm. Nibgeeans are not easy to associate with as they always suspect what the outsiders are doing in their place even at the Gabriel celebration time. The only way to gain acceptance is to show that you respect their ways. The researcher used his knowledge of the local culture to blend in.

The researcher stayed in the monastery for the six weeks he was in Nibgee, which helped him to get to know the newly appointed high priest of the church and gain the respect of the community. In the Coptic Orthodox religion there is no restriction of alcohol use so long as it is not abused. Most of the high priests, priests and deacons drink the same local alcohol as the village people, Tela ${ }^{30}$ and Areke ${ }^{31}$. From their perspective, a visitor who does not participate in their feasting by drinking this alcohol would be recognised as being from other denomination of Christianity, which would create a gap and probably make them unwelcome with everyone in the valley. Therefore, on all the occasions when the people were drinking and eating, the researcher felt that participation was obligatory to harmonise the situation. This method prevented the locals from becoming suspicious that he was from another denomination of Christianity. The researcher also ate the local food and, in all ways possible, lived like a local. In addition to this he took photographs of locals and gave their pictures to them. When other people asked for photographs it gave the researcher an opportunity to communicate with them. He knew that this strategy had been successful because they continued to welcome him into their homes.

\section{Rationale for fieldwork}

Having seen and experienced the dangerous and narrow path into Nibgee, the researcher wondered why the locals stayed in that place instead of up the hill and whether they wanted a proper road. When the researcher talked about the community's development needs and the support they had received up to that time, he was surprised at first by the way they explained their situation and quickly become conscious of their courage, and indifference to development. Anxious to avoid the pitfall described by Chambers (Chambers 1983), who expressed his concern regarding how visitors are easily biased with

\footnotetext{
${ }^{30}$ Local alcohol which is made mainly with a combination of barley and maize which resembles beer.

31 A strong colourless wheat alcohol made by a process of distillation 
regard to rural development based on the persons they meet, the researcher decided to conduct systematic investigation to gain a more accurate and representative picture of local attitudes with regard to development in Nibgee. In order to achieve this better understanding of the Nibgee community, the fieldwork had to be conducted on site and evaluated by: crosschecking or triangulating focus groups using [PRA methods], unstructured interviews, and direct observations (Chambers 1983; Chambers 1997; Kumar 2002). These three different methods were deemed necessary as there was no guarantee that the Nibgeeans would tell the whole truth through any particular method.

Unstructured interviews were selected because the Nibgeeans are a communal minded culture, and any answer given in a group situation may have been influenced by the opinions of the others and the results would have been all the same. Observations were merely to get an idea of who particularly used the path and to whom the road would be especially important. Before the fieldwork began the researcher had mobility mapping in mind. However, as it turned out, observation and one-to-one interviews were sufficient. Instead, dream mapping was chosen to discover what sort of development they really wanted. Social mapping was chosen to get a better understanding of who lives where to help choose the interviewees.

\section{The Research}

The researcher started field work by meeting a mediator, with whom he had previously established communication over the telephone. Although the mediator was also an outsider, he belonged to a road committee and knew the valley and its people very well. He also had relatives living near to and down in the valley. Following that initial meeting in Addis Ababa, and after several conversations over the telephone, the mediator succeeded in making an appointment with the head official responsible for that valley and five surrounding villages ${ }^{32}$, to gain permission to conduct the research. At the meeting they discussed with this gentleman all the activities that the research would involve. Without any further appointments or interrogation, the official confirmed that the research could carry on so long as it dealt only with development matters. Later that day, researcher found out why that was so very important. In the 2005 Ethiopian regional elections, all the villages in that area had nominated representatives from the opposition party and researcher was warned not to involve himself in political discussions.

${ }^{32}$ In Ethiopia each village is called kebele. 
The researcher's initial contact with the official was only made on a Friday, but he and the mediator went to the village on foot the very next day after spending the night at the house of the mediator's relative that lived near the valley. The walk to the village was arduous, difficult and dangerous. It took about one hour over the hills and another one and a half hours to get down a narrow path into the valley. At the mediator's request, two boys from the village were waiting at the top of the path to carry his and the researcher's belongings and hand them walking sticks. The boys gave them brief instructions of how to navigate the treacherous path into the deep valley safely. The mediator, who was very familiar with this community, chose Sunday at a regular church meeting as the best time and place to introduce the researcher and disseminate information regarding the research. The church was the best place for this, because almost all the community gather there unprompted; and it is the usual place for people there to get community notices. Therefore, that night both the mediator and researcher stayed as guests in the monastery. With the help and invitation of the newly appointed head of the church, the researcher was allowed to stay freely in the monastery throughout the duration of the research.

Early the next morning the researcher and mediator got up with everybody else to attend the church ceremony at six o'clock. The service finished at half past nine, which is when the locals were given notice by the priest, and the mediator began his introduction. After introduction by the mediator, the researcher was invited to the stage to explain his intentions and inform them of how long he would stay. The researcher introduced himself to the community, acknowledging the kind invitation of the priest and mediator. He said that although he lived abroad, he came to learn from them, and explained the meaning of development, briefly outlining the purpose of his research in development issues. He emphasised that he came from New Zealand and did not have any intention to become involved in politics or have any link either with national or local government officials. He explained why he was initially drawn to their village and what his intentions were. He explained what the villagers could expect at the end of the research, emphasising that it was for educational purposes only. The researcher elaborated on the sort of activities that he would be doing and let them know that he might pop in to their front gate during his time there, for an interview. Mainly, he stressed the point that he was not a government agent and had no links with anyone official in Ethiopia except the mediator who had finished his duty when he introduced researcher to the community.

In the Coptic Orthodox religion the Sabbath is not the only compulsory holiday. There are many holidays which the villagers have to recognise saints days. Approximately half of 
the year is recognised as a holiday by the church and it would be great abomination if any one broke this belief. The consequence of breaking these holiday obligations is believed to be a catastrophe sent by God [See appendix 4]. The research took place during the wet season so it rained a lot. Despite this, if it was a working day everybody worked and even the students were forced to stay at home to work. Many worked on ploughing the farmland with the help of oxen; others followed with diggers to dig those hills which were too steep for the oxen; others were planting crops.

\section{Methods}

Four of the intended six methods were employed in this research: direct observation, resource mapping, dream mapping, and unstructured interviews. Mobility mapping proved impracticable to do separately so information meant to be gained from that was instead gained in the interview. Social mapping was done informally at the same time as the resource mapping.

\section{Resource Mapping}

Of all the focus group activities, resource mapping was conducted first. Fortuitously, the teachers in the village, who command a great deal of respect in Nibgeean society, volunteered their services and helped the researcher set up the activity. Participatory Rural Appraisal (Borton 1995) was explained, as was the purpose behind the activity and how it would be conducted, observed and of course how to set up all the basic instruments before the actual time of the activity. The teachers' help made all the procedures easy. While the teachers supervised the assigned activities, the researcher observed the general situation and met most of the villagers.

The participants got the idea of resource mapping easily. The first participants let the next people know that it was fun and helped them to understand the information that was needed to participate. They enjoyed spotting their farm areas and approximately where they were living. At times they corrected others who wrongly identified their house by mentioning who bordered on their property and so on.

The activity started with participants writing a series of numbers on a poster-type sheet of paper, which already contained the dominant figures of the church, the school and the path. The teachers' residence was the starting point and was given number one and it 
carried on in no particular order. The teachers pointed out everybody's houses and said who their neighbours were and passed the pen to the participants to carry on. The researcher started observing and helping writing the numbers in the meantime - writing the names and the numbers from the activity sheet in a different note book to record exactly who lived where. This enabled the researcher to get to know the area better. In fact, those who were in a hurry to be somewhere else apologetically left the activity after arranging for their neighbours or friends to record their exact place of residence with their respective coordinators.

This activity boosted researcher's confidence as he was pleased by the kind cooperation he received from the villagers and so he prepared for the next Social Mapping activity. The researcher took a lot of photographs and promised to present the participants with their pictures at the next meeting. This was a key icebreaker and served as a foundation for further positive relations with the community for the duration of his stay. At the end of the research, the majority of the village people had at least two or three pictures.

\section{Social mapping}

This particular PRA method was intended to stimulate dialogues between the different participants to help researcher to have a better picture of the local demography. These activities were used by Leurs (1995) and Kumar (2002). It was intended to be a group activity which should have helped researcher to identify the key people in the village and those different social subgroups including widows, couples, and people from the church.

The participants were supposed to move into their own groups [women, young men, old men and church people] and rank themselves from highest ranking or most respected to the lowest ranking in order to better illustrate the social structure of the area. However during the first and only group session, the participants were puzzled and seemed to struggle to understand researcher's aim and wishes. Perhaps they did not want to show that they had a different view to the majority. Alternatively they may have found it socially uncomfortable to acknowledge rank publicly. For whatever reason they refused to show who was more important than whom. Although the researcher described everything as clearly as possible, he could not convince them to participate. Undaunted, the researcher tried another tactic and posed the relevant questions to individuals instead. The one-to-one method proved more successful. 
The researcher used his growing of awareness of who was who and where people lived in order to arrange interview appointments.

\section{Unstructured Interview}

Unstructured interviews were chosen for this village because they provided in-depth information, making it easier to diagnose the problems and clarify the villagers' attitudes towards their own development and how they regarded themselves in comparison with those who lived up the hill. Not all of the people scheduled for interview were willing to cooperate but researcher got a good chance to speak with most of them at length.

All the interviews were conducted in Amharic language as the researcher spoke and wrote the language. Nevertheless a few participants did not understand why someone would come to live with them and study about them. They were reluctant and hesitant to speak even when the researcher explained his intentions.

\section{Dream mapping}

The final research method employed was dream mapping (Kumar 2002). Dream Mapping was not in the original research plan. However in the course of the research, while visiting the village the researcher noticed unfinished or damaged development work. The road, which was started eighteen years ago, was the most obvious one and had two bridges that were partially washed away standing alone side by side without connection to any road or without even joining the two ends. The researcher wondered if the problem behind this was simply that the villagers were not interested in the road. There was also a completed but unusable water system. Owing to this the researcher designed a dream mapping activity and organised a group of seven from each group: young men, women, old men and church people.

The researcher handed each participant five pebbles to place on large poster type sheets of paper to show what they chose or prioritised from five development options previously decided on by the researcher. These categories were: water, road, clinic, electricity and school. The researcher explained all five choices then the participants were asked to put the pebbles in whichever of the sheets displayed their heading of choice choices. They were asked to place their pebbles according to their prioritisation of the importance of the infrastructure that they most wanted to have built in their village. All the participants 
prioritised what they wanted. Unlike the other social mapping activity, the villagers did not hesitate to participate and were happy to be offered a choice.

\section{Observations}

Direct observation was carried out most mornings and evenings with a brief salute and conversation with the villagers that used the treacherous narrow path. As it was difficult for two people to use the path at once, it was easy to sit either at the top of the road or down at the bottom and note whenever anyone used the road. The persons who most commonly used the path were young students whose school was at the top of the hill. The newly opened Nibgee School only takes students from first grade to third grade. Once they finish grade three, the next step is to gain the permission of their family for the children to go to the school up the hill, which accommodates up to eighth grade. The children were helpful, and whenever they saw strangers they would guide them and carry their belongings. The students travelled in pairs or groups for safety.

Direct observation was intended to provide qualitative as well as quantitative information (Coolican 2004:50) to exactly define current patterns of path use. A diary was kept each day to record comments and conversations; however it seemed redundant to try and keep a precise tally, so general impressions of path use were deemed sufficient. This observation method helped to build a sufficiently accurate picture of who used the road and how often. It also highlighted the importance of the road to this isolated community.

\section{Barriers to research}

There were several physical, social, and methodological barriers to research. Most obviously, the first difficulty was the location. To go up and down the treacherous, narrow and steep path was both dangerous and difficult and had to be undertaken at least once a week to get supplies and get photographs developed in the capital city. During the observations, the topography proved difficult to go up and down as desired, and it took some time to recover and become energetic again. The physical difficulties also included dogs, flies and fleas. The dogs in the village were vicious and no-one controlled them. If one dog started barking, every dog in the village came running. Although this was a common occurrence for the villagers, and they knew how to handle the dogs, the researcher was afraid and had to carry a stick everywhere he went and twice had to put his back against a tree to prevent the dogs biting him from behind. The flies and fleas often 
bit the researcher and could not be avoided. Furthermore, due to the unfamiliar schedule and real hardships the researcher became tired.

It was very hard conducting interviews at night as the monastery was bit far from the village, and with no power there were no lights. Also night-travel was scary with those vicious dogs. The geographical location forced the researcher to stay in the village for days at a time as it was not easy to climb out of the valley. The Nibgee community was spread over a large portion of the valley and they lived quite a distance from each other. It would have been tedious to speak with all the community, therefore the researcher chose interviewees by cluster sampling to give a representative picture of the views of the entire population (Coolican 2004:50). The teachers help him to choose according to perceived importance to the research.

The social barriers to the research were cultural and attitudinal as previously mentioned as

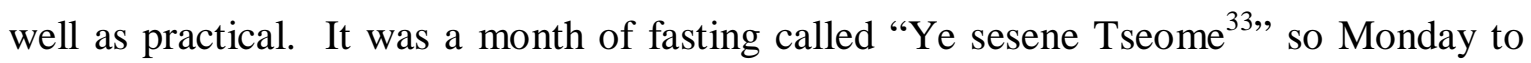
Friday church started from one in the afternoon and continued for two hours until three, however in Coptic Orthodox church ceremonies are held without any food or drink. The monastery is a place where every doctrine of the church most respected therefore researcher did not eat until three in the afternoon from Monday to Friday. At times the researcher suffered from dehydration and hunger. Another social barrier was gaining the trust and acceptance of the locals. As Spencer (2004:206-207) states, it is of paramount importance to overcome distrust of locals before any form of development or research can proceed. The reticence of participants was not totally overcome, however; and this showed in the social mapping activity when people were unwilling to acknowledge who was subordinate and who was superior. Although the researcher planned to do social mapping as a separate activity, after diagnosing the issue and understand the people's attitudes, it appeared that participants would be more forthcoming on a one-to-one basis rather than in a group.

The most frequent travellers on the path were the students and the majority of them were below eighteen years of age, which prevented their inclusion in this research. Furthermore, there was some reticence with regard to the interviewing of women as the researcher is male. He was reluctant to damage his reputation by meeting women unaccompanied by their male kin. Being in a monastery he especially did not like to

${ }^{33}$ Ye Senai Tseome is June fasting month. 
create any ambiguous impressions which could potentially become a barrier to the entire research

In order to not waste their valuable time, the researcher chose dream mapping and dropped the mobility mapping exercise which was found to be unnecessary as the observations and the interviews achieved the desired results. He applied dream mapping to triangulate with the observations and interviews. Dream Mapping was used to discover how the villagers prioritised different infrastructures.

\section{Ethical considerations}

An 'informed consent' form was read to each participant before their interview to ensure they understood their rights. To maintain anonymity the thesis did not expose the name of the participants, instead codifying them into two groups: men ' $\mathrm{M}$ ' and women ' $\mathrm{W}$ ' and giving them different numbers so that nobody could trace what any particular person mentioned in the one-to-one interviews and observations ${ }^{34}$. Interviews were conducted informally in the people's homes early in the mornings because during the days they were all busy, and during the evenings there were dangerous dogs roaming around. There were twenty-five interview participants in all. Each participant was classified as either 'Young' [older than 20 but less than 60] or 'Old' [older than 60]; 'Man' or 'Woman'; 'Church person' or 'Layperson'. A Church person was anyone who worked for the church including the church gardeners and store-men as well as the deacons and priests. There were twenty men and five women in the sample group. All seven Church people were male. The other thirteen men and the five women were laypeople. Fourteen of the participants were classified as young and eleven were old. No comments from persons under eighteen years of age were included in the research. Local customs were respected and adhered to as closely as possible to avoid offending the locals. Research materials are being kept in a safe place and will be destroyed after five years. The researcher intends to report the translated final findings and recommendations of the research back to the community through the mediator after completion, and will inform them of where to find the final copy of the thesis. It is intended that this research will serve as a precursor to and rationale for future development in the area.

\footnotetext{
${ }^{34}$ This process was passed by the Victoria University Ethics Committee. 


\section{Conclusion}

This chapter has discussed the rationale of this research, the four methods used in the research, barriers to research and ethical considerations. It is intended to give this thesis a touch of reality, these methods helped provide the data outlined in the next chapter entitled Results. 


\section{Chapter 5}

\section{Results}

\section{Introduction}

This chapter presents the findings of the surveys carried out in Nibgee village in June and July, 2007. The central question was how the citizens of Nibgee regard their own development - whether they subjectively experience deprivation, or whether they are happy as they are. This is covered in the sections headed 'Local self-perception' and 'Prioritisation of development initiatives'. The secondary questions were about how Nibgee villagers compare themselves with the Highlanders ${ }^{35}$, how they perceive past development initiatives, and how important they consider road development. These are covered in the sections headed 'Local Self-Perception', 'Past Development initiatives' and 'Attitudes towards past development initiatives' and 'Attitudes towards the development of a road'. The third method used was 'direct observation' from which anecdotal impressions of path use were gained. This was done in order to understand how Nibgeeans use their narrow path to ascertain whether the road is important or not. This as well as interview data about path use is discussed in the section labelled 'Path Use'.

Observations were carried out almost daily and villagers who used the narrow path were observed from either the top or the bottom of the valley most days over one and a half months. Informal discussions took place as people went by to gain information about the path from outsiders as well as Nibgee villagers and impressions were recorded in a daily diary.

The dream mapping participatory activity was done at the end of the researcher's stay and a total of twenty-three villagers were involved. For simplicity, they were divided into three categories: eight church people, eight women and seven laymen [see Figures 5-9]. Church people were categorized separately because they are the ones who hold the real power in the village.

${ }^{35}$ Degegna or people who live up on the flat-land, not down in the valley. 


\section{Local self-perception}

\section{Interview}

“How do Nibgeeans compare with Highlanders?”

This interview question was answered by twenty-four people. Overall 56\% of participants thought that Nibgeeans were better than Highlanders, 38\% thought that Highlanders and Nibgeeans were equal, but only $6 \%$ of participants thought that Highlanders were better than Nibgeeans.

Figure 1 : Self-perception when compared with the Highlanders

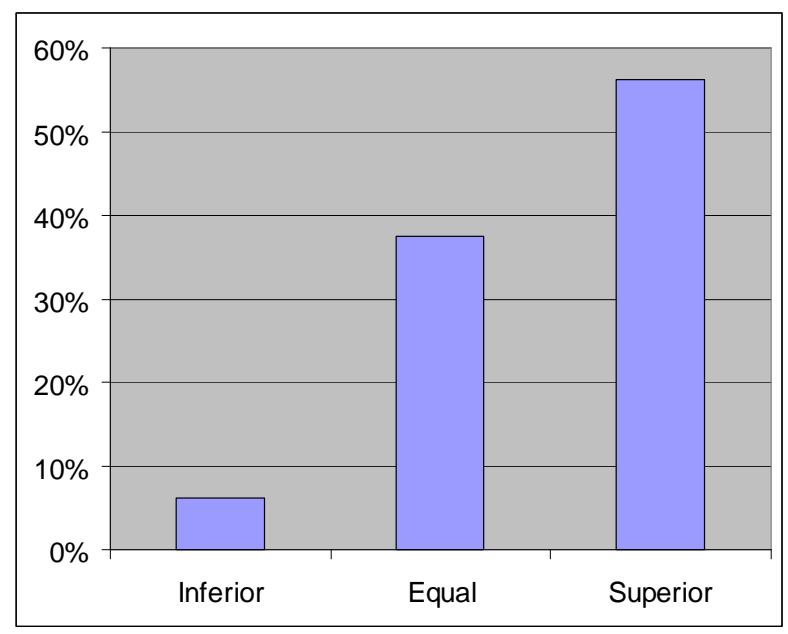

Those who said the Nibgeeans were better cited the types of crops as a reason for their superiority. Teff could be grown in the valley but not in the highlands in the immediate vicinity. The Nibgee villagers also regarded themselves as self-sufficient hard workers and the highlanders as lazy unproductive types. They based this assumption on the quality of the farming land available to each of them respectively. The work is very hard in Nibgee as the land is so steep and rough. They acknowledged that the people in the highlands had plateaus which suited planting trees, livestock husbandry and farming and had more land; but maintained that despite all these natural advantages, which favoured Highlanders, the Nibgee villagers were better off economically.

Figure 2: Self-Perception when compared with Highlanders [interviews] 


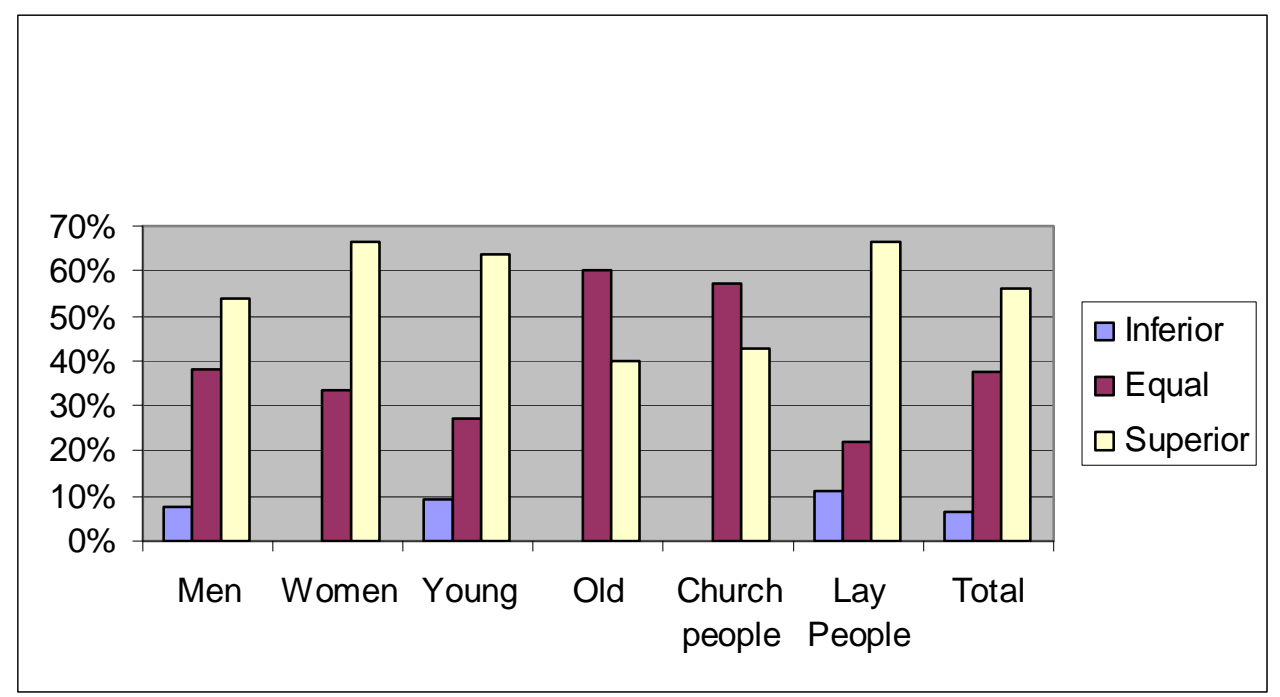

When analysed according to the demographic groups mentioned above, older people and church people were more likely to rank themselves as equal rather than superior and none of them rated themselves as inferior to Highlanders. On the other hand, an overwhelming majority of the women, the young and the laymen said they felt superior to the people living in the highlands. And the few who said they were inferior felt disadvantaged by their landscape and isolation.

From observation, Nibgee people appear to have a positive view of themselves. They are proud of their ability to farm the difficult terrain and feel that they are better off financially because their crops are currently worth more money than those grown up the hill. They feel that their place is blessed and that it fulfills all their needs. Most of them have been to Addis Ababa but it was too crowded for them and they could not act as they liked and were confused so they did not feel great there. Hence they prefer their own place where they can feel content. The church people and old people, although they said they were equal to the Highlanders, seemed to be masking their real attitudes behind religious jargon. In fact they obviously considered themselves better off.

\section{Local concepts of development}

"What does 'development' mean to you?"

\section{Interview}

Figure 3: Concepts of Development 


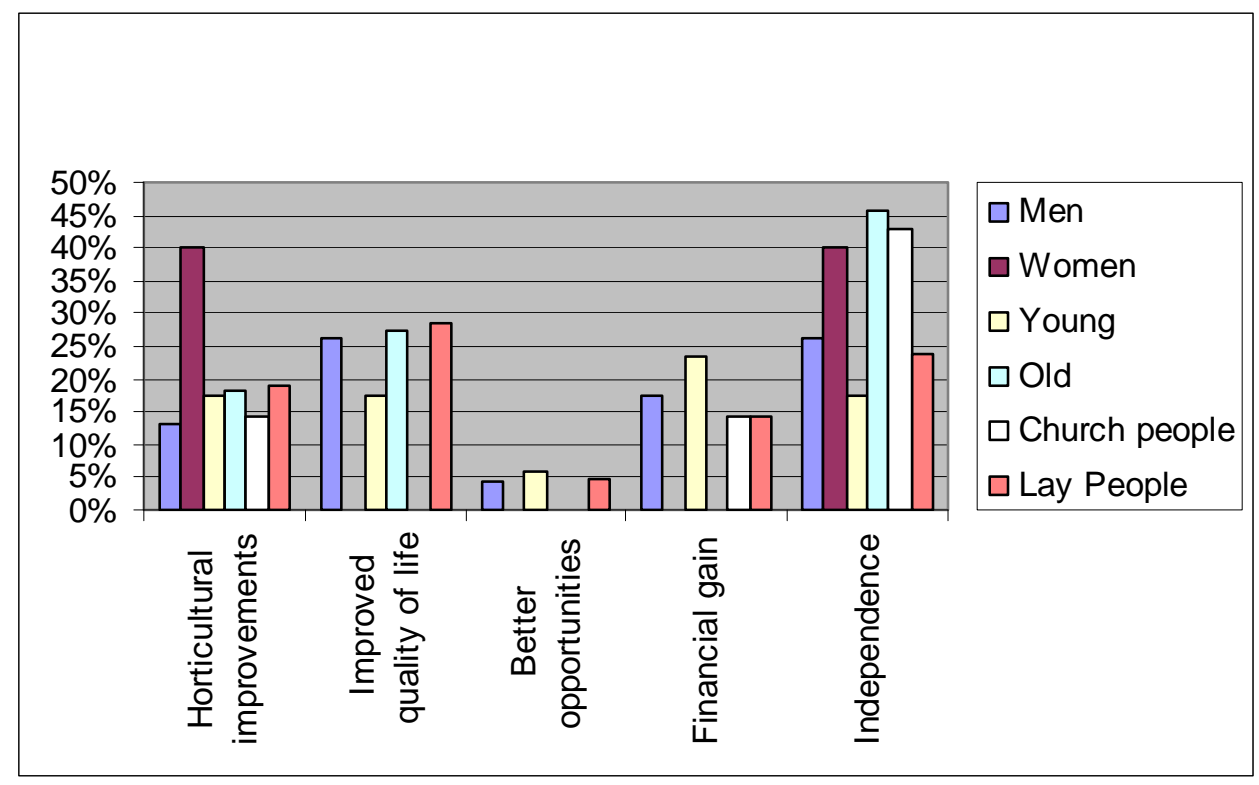

Because these were unstructured interviews, rather than questionnaires, the answers were varied. The answers did, however, fall into five general categories which were things that facilitated horticultural improvements, financial gain, improved quality of life, better opportunities or independence. Several people mentioned more than one concept.

The Nibgeeans' concepts of development were very much tied up in the realties of their everyday existence and their own values. The most prominent and popular concept of development for everyone except the young was anything that allowed them to live independently. The young valued financial gain more whereas the old people did not even mention ‘financial gain' or 'better opportunities'. Old people, church people and women expressed the idea that development was anything that induced independence. Women saw anything that enabled them to grow better or more crops as equally important to 'independence'; but both these things relate to 'being able to feed oneself and one's family so as not to be hungry today'. Horticultural comments were mainly focused towards getting a wider variety of edible crops and planting trees. No one really cared about 'better opportunities', but 'improved quality of life' was what most laymen considered to be development and it was the second most highly prioritised aspect of development for men overall. Old or young people were equally likely to cite 'improved quality of life' but no female and no church people chose this. The difference between 'quality of life' and 'opportunities' was that 'quality of life' meant simply making what they had - which was already good to better; whereas answers classified as 'opportunity' related to getting the chance to do new or different things such as getting jobs up the hill, eating different foods, or not being limited to living the hard life of a Nibgeean. 'Independence' for them meant 
being able to work hard to feed themselves and their families.

In summary, 34\% of respondents mentioned independence, $24 \%$ improved quality of life, $21 \%$ horticultural improvements, $16 \%$ financial gain and only $5 \%$ better opportunities. In fact, as mentioned above, horticulture and independence were particularly related.

\section{Local attitudes towards development}

"What do you think of your own development?"

\section{Interview}

Figure 4 Attitude towards Development

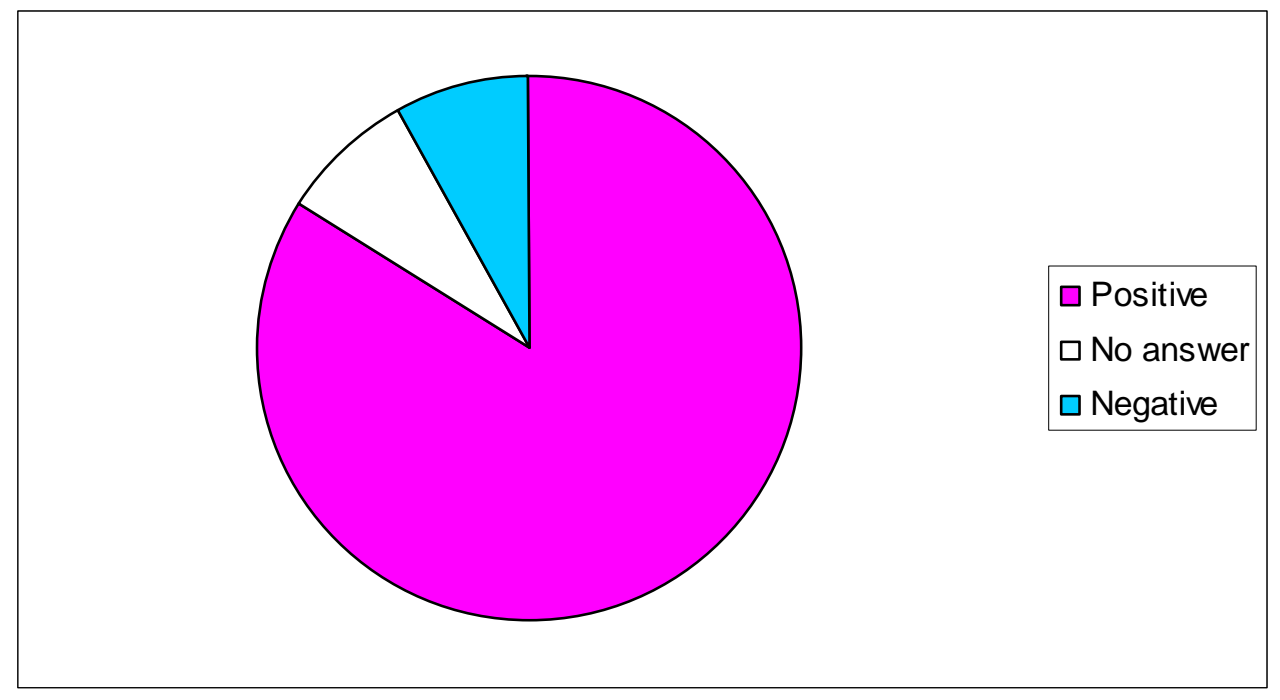

The people of Nibgee mainly reported having a good attitude towards development. This is because of their above-mentioned concepts of development. However the more widely accepted ideas of 'development', such as infrastructure establishment, elicited quite a different response [See Figures 5-8].

\section{Past development initiatives}

"What do you think of the development work that has been done already?"

The people of Nibgee generally seemed to have a cynical attitude towards outside instigated development. All that development meant for them was working hard, as that had been the extent of their involvement in the past. All except one of the past 
development initiatives were not functional.

Participatory development techniques have never been used in past development projects in this village. The outsiders imposed their ideas about what they felt the village lacked on the locals. All interviewees, and people talked to in the course of the observation, said that they had not been advised before about any past development project. All agreed that the outsiders came and told them what they would do for them, but none had enquired about what the locals needed or offered them a choice. Most Nibgeeans had given their free labour to development initiatives because they were requested by the local church.

There were five obvious examples of past development initiatives: The road, the water pump, the mill, the school and the new church. They were all at various stages of completion. The road was not finished; the water pump had been functional but was no longer working; the diesel-powered mill was working well, but because of the high price charged there the Nibgeeans preferred to use the electric mill up the hill. The school is functional despite a lot of challenges and the new church seemed likely to be completed in the near future although its original sponsors had pulled out. When asked why they had taken it upon themselves to independently finish the church rather than any of the other development projects, one lady [F1] answered:

"This is for the good of our soul."

All of the twenty five villagers interviewed responded to this question. The water pump was the brain-child of one teacher [M4] but it was not maintained properly and it was forgotten after it broke down as the locals did not care to spare any money to fix it. [M4] was even suspected of embezzlement because of his initiative. In fact the source of the finance for the pump was legitimate but was kept secret because he feared upsetting the Coptic Orthodox church. The mill was exclusively used by the church because for them it was free and it was also used by the villagers who could not get their crops up the hill for whatever reason. One church person [M6] said that he wished that he could ask the sponsor why he did not lower the price. In fact the church gets any profits that the mill makes but this is kept in a bank under a separate name to avoid having to give it to the Central Church $^{36}$. The local church does not use the money itself, but spends it on wages for mill workers, maintenance and fuel. The new Head Priest seemed likely to challenge the status quo so the Central Church would regain its authority. The school has been open

\footnotetext{
${ }^{36}$ In Coptic orthodox the central church the head of all the Coptic Orthodox churches and share the income of all the churches.
} 
for the last three years and caters for approximately 109 students. It operates without desks, chairs, or windows and with a chopped remnant of a black board. It only takes students up to grade three, and the $30 \%$ funding from the government barely covers the three teachers' wages let alone any resources. On the other hand the new church has beautiful brick walls with windows carried from the capital city. The doors are well framed with metal and have glass windows in them. The inside has not been finished yet but, at the time of the research, the villagers were highly dedicated to finishing it in time for the upcoming celebration of Gabriel on December $29^{\text {th }} 2007$.

\section{Prioritisation of development initiatives}

\section{Interview}

"What development alternative would you prefer out of water, school, power road or a clinic?”

Figure 5: Preferred Development Option [Demographic breakdown]

\begin{tabular}{|l|llllll|l|}
\hline Participant & Water & School & Power & Road & Clinic & No preference & TOTAL \\
\hline Men & 4 & 1 & 5 & 3 & 0 & 7 & 20 \\
Women & 3 & 2 & 0 & 0 & 0 & 0 & 5 \\
\hline Young & 3 & 3 & 3 & 2 & 0 & 3 & 14 \\
Old & 4 & 0 & 2 & 1 & 0 & 4 & 11 \\
\hline Church & & & & & & & 7 \\
people & 2 & 1 & 4 & 0 & 0 & 0 & 18 \\
Lay People & 5 & 2 & 1 & 3 & 0 & 7 & \\
\hline TOTAL & 7 & 3 & 5 & 3 & 0 & 7 & \\
\hline
\end{tabular}

Of the twenty-five interviewees, seven did not mind what they got as long as it was free. Nobody wanted clinics. Water was overall the most popular choice for women, the old and laypersons. Schools were the second most popular choice for women. The young were equally interested in schools, water and power and only slightly less so in road development so no clear preference emerged. The old had no interest in schools at all.

Power appeared to be the most popular choice for both church people and men. But, when checked for possible bias due to the fact that the church people were all men it 
became apparent that roads were a very slightly more popular choice for laymen than water followed closely by schools and power. The difference between them, however, is too small to be significant.

Contrary to expectation, nobody apart from the three lay 'men' prioritised roads very highly. Roads were the second most preferred option for young people and laypersons in general; a distant third for the old; but did not rate at all for women or church people.

Participants were advised to rank these five development options in order of preference: power, a clinic, a new school, a road and water.

Figure 6: Preferred Development Option

\begin{tabular}{|l|l|l|l|l|l|}
\hline Participant & Power & Clinic & School & Road & water \\
\hline $\begin{array}{l}\text { Church } \\
\text { people }\end{array}$ & $73 \%$ & $5 \%$ & $8 \%$ & $13 \%$ & $3 \%$ \\
\hline Women & $8 \%$ & $10 \%$ & $69 \%$ & - & $13 \%$ \\
\hline Laymen & $53 \%$ & $14 \%$ & $6 \%$ & $17 \%$ & $11 \%$ \\
\hline Total & $44 \%$ & $10 \%$ & $28 \%$ & $10 \%$ & $9 \%$ \\
\hline
\end{tabular}

Figure 7: Preferred Development Option [PRA]

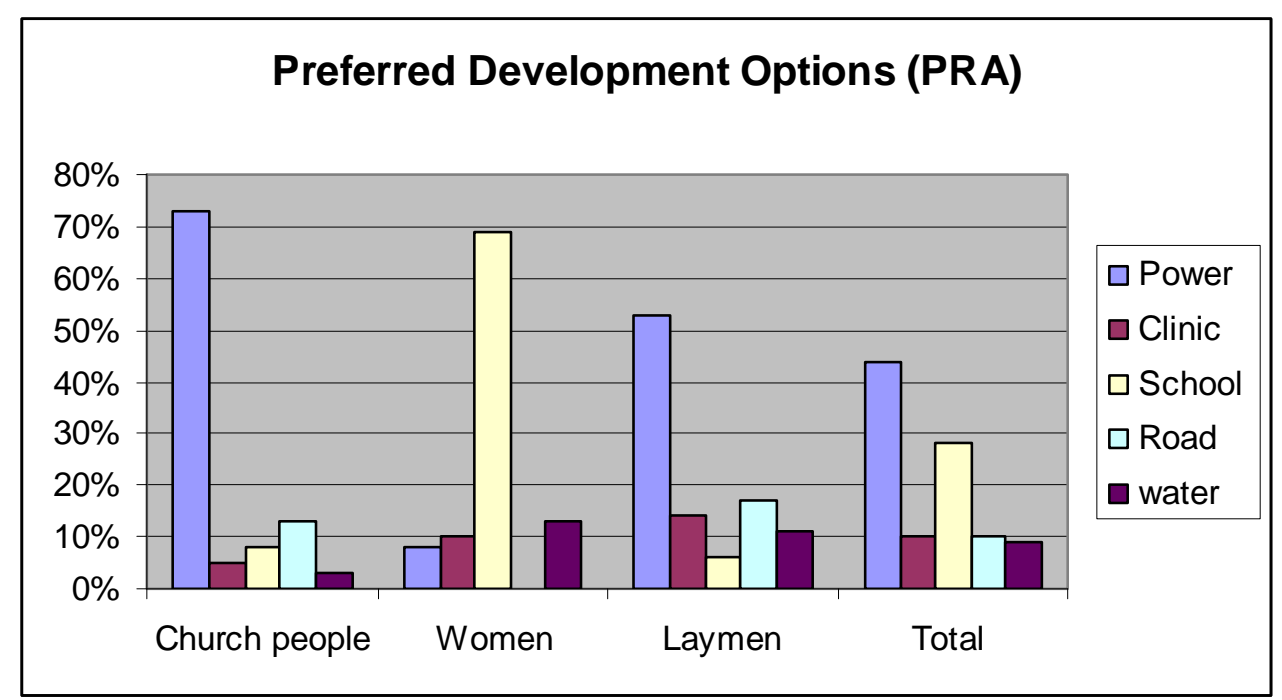

According to the survey, power was ranked first and got $44 \%$ of participants' votes, schools got $28 \%$, and clinics, roads and water got $10 \%, 10 \%$ and $9 \%$ respectively. 
The road and the clinic came a distant third-equal to the school and power. Schools were clearly the most preferred option for women with $69 \%$ of women's votes, whereas power was the most preferred option for both church people [73\%] and laymen [53\%]. Because the laymen and church people were all men, women were outnumbered two to one. Hence, when mathematically adjusted by dividing the product of the laymen's and church people's votes to make men's votes of equal weight with the women's votes, school suddenly became the most favoured option, with 38\% and roads were least preferred with 7\%. With 35\% Power was still a very popular choice, nearly equal to schools.

Figure 8: Mathematically voices adjusted

\begin{tabular}{|l|l|l|l|l|}
\hline Power & Clinic & School & Road & Water \\
\hline $35 \%$ & $10 \%$ & $38 \%$ & $7 \%$ & $10 \%$ \\
\hline
\end{tabular}

$73 \%$ of the church people preferred power and only $13 \%$ of them chose the road.

The above results clearly illustrate that the participants' first priority is not the road. The church people are keen to have power and they did not value the development of a clinic, school, road or water. The women chose the school and if given equal weighting with the men's votes the women's preferences skewed the results towards schools.

It was apparent from the discussions that surrounded this group that young men prefer power to any other thing including roads. In the group discussion there were about forty participants and all of them agreed on the importance of transport and how it would be easy for them if their area was accessible and mobile but only 2 out of 40 people chose the roads. Both clinics and roads gained around $10 \%$ of the votes and were among the least popular of all the options. With only $9 \%$ of the votes, water was ranked as the least preferred development option. This is the opposite of the interview results according to which water was the most preferred option. This discrepancy may be accounted for by the absence of old people in the PRA activity because, when adjusted for gender, water was still only third equal.

\section{Transport}

"How many times did you go up the hill in the last month?” 
This interview question was answered by 24 people from all demographic groups. Although reported path use ranged from once in three years to fifteen times a month, the records were simplified and split into three categories: less than once a week, weekly and more than once a week. Results showed that most people in Nibgee use the path more than once a week.

Men and young people are the most frequent users of the path and use it more than once a week. However most of the women in the village used the narrow path only once a week. Old villagers were the least frequent users of the path, as it was tedious and difficult to climb.

Figure 9: path Used

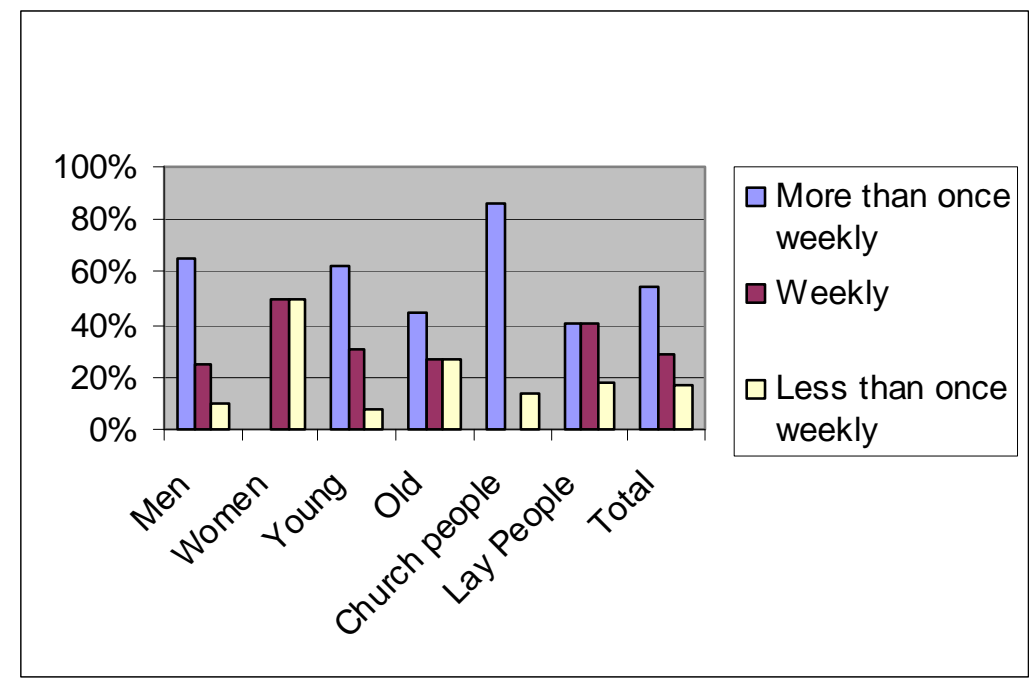

On weekdays, students were the most common travellers on the path. They left early in the morning going upward and they returned to the valley at around $4 \mathrm{pm}$. They travelled every day except for the school holidays, weekends and public holidays. They did not have to observe the local holy days. There were more holidays than working days in the valley [See appendix 4], and during their holidays, very few people went up the hill. Purpose for path use was discussed with as many people as possible in addition to the interviewees. Apart form the students, the majority of villagers go up the hill more than once a week either to take produce to the market, buy goods, visit relatives or use the electric flourmill.

Saturday and Thursday are market days for the villagers. The Saturday market is further away than the Thursday market so fewer travellers go there, and many individuals or 
groups went to the Thursday market carrying their goods or driving goats or donkeys. Travelling time began early in the morning with the dawn in order to reach the market on time. On these days the narrow path was much used.

The only exceptional occasion that I observed was a funeral when the majority of the villagers walked up the hill in lines to pay their respects. That was the day I saw almost all the people in the village and the neighbouring village's people on the path. They announced the event by shouting from the valley to the hill areas where everybody listened and came to pay their respects. This was the way they conveyed messages whenever they acknowledged an event like death. They even yell individuals' names and addresses for personal messages

The 12th day of every month is known as the day of St. Michael and is recognised as a holiday [see appendix 4] when people go up the hill to another church to pay homage. In the same manner, when it is the day of St. Gabriel [the $19^{\text {th }}$ ] or St. Mariam [the $21^{\text {st }}$ ], which are celebrated down in the valley, many visitors come from everywhere. Many people on the path explained how they suffered from the state of the road, but the intercession of St. Gabriel was always relied on for assistance. The villagers always claim that if you come with a pure heart to pay respect to the church, the spirit of St. Gabriel will support you to fulfil that aim.

\section{Attitudes towards the development of a road}

Eighteen years ago some outsiders attempted to build a road from the top of the Nibgee cliffs to Nibgee village down in the valley. It was started in 1989 but it is not yet finished. I interviewed the villagers about their attitudes towards the unfinished road. An old man [M1] said:

"We did not have cars we had donkeys so our simple path was sufficient for us. We really did not know why they wanted us to make the road. They tried to build it for themselves [outsiders] not to help us.”

He did not appreciate the outsiders' efforts to build the road nor could he see the value of the road or what it could add to their life. Twenty four people were interviewed about their attitudes towards the road, and his opinion was fairly typical. Eleven of them answered 
that they did not know what the road brings for them. Although their words were noncommittal and had to be recorded as such, these eleven villagers were in fact sarcastically informing me that they were very opposed to the road being built so the graph labelled 'interviewer's impression' is the more accurate. However six people responded that the road was important and key to their own development for bringing many pilgrims to the village, which generated income for them by buying whatever food crops they had. Contrarily six people openly confirmed that they were opposed to the road, which they felt jeopardized their heavenly life. Two people were definitely neutral.

Figure 10: Attitudes to Roads [interviews]

Figure 11 :Interviewer’s impression of Road
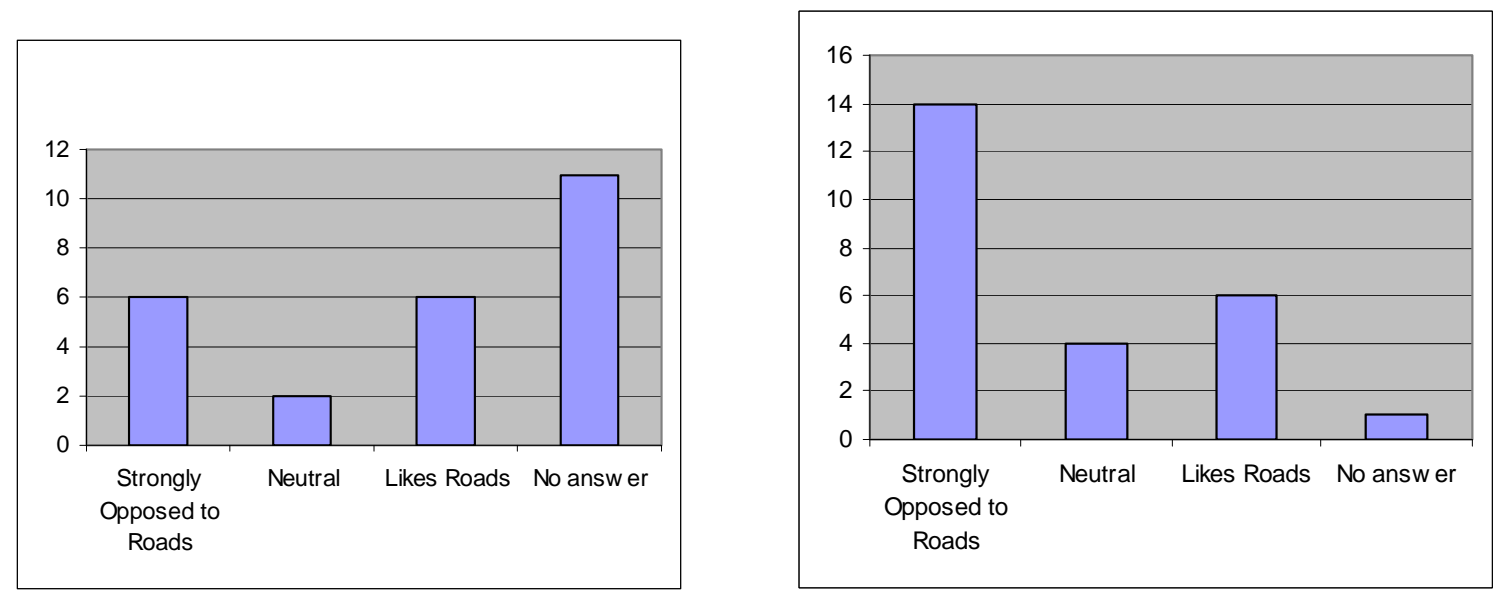

Dream Mapping was conducted to find out what the people of Nibgee actually preferred including building road. Church people had forty chances to choose, however out of the forty, only five chose the road and the rest ignored the importance of the road. None of the women, who had thirty nine chances to vote for the road, chose it. Men, who had thirty six chances only exercised six of their chances for road.

\section{Aid during the Famine}

Figure 12: Received aid for work up the hill during the famine of the 1980s 


\section{Received aid for work up the hill during the famine of the 1980s \\ (Interviews)}

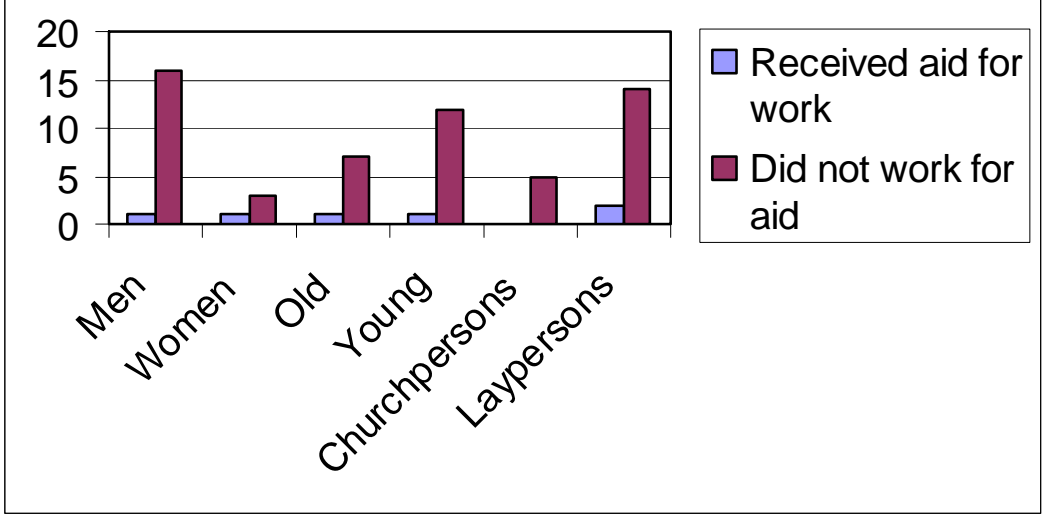

Only two of the twenty-one interviewees who answered this question had gone up to work for cooking oil and wheat during the famine of the 1980s. One young church man [M19] was too young at that time to go up the hill to work. The other eighteen did not go up because they did not want to go. They managed with what they had in the valley and had to sell many cattle. They also shared with each other and used stored grain.

\section{Conclusion}

This chapter has examined the results taken from interviews, observations and a PRA group activity conducted in Nibgee village in June - July 2007. The findings were depicted both in words and graphically, and covered seven basic conditions: local selfperception; local concepts of development; local attitudes towards development; past development initiatives, what types of development work they preferred and their attitude towards the road; and finally whether they subjectively experienced deprivation or received aid during the time of famine.

Nibgeeans predominantly have a positive view of themselves and this was apparent throughout the direct observations and interviews and in social situations. Development for the Nibgeeans was mainly related to not being hungry. 'Horticultural improvements' and 'independence' were both related to that primary aim. 'Improved quality of life' also featured as a definition of development for Nibgeeans. Local attitudes towards development reflected their two real life concepts of development. First was their concept of development, which as previously mentioned, was anything which helped them to avoid hunger. They were overwhelmingly positive about this. Second was their attitude 
to past development initiatives including the road: those were inextricably linked in their minds to hard work for little benefit. Hence the responses about this type of development were mixed. The results regarding their preferences for future development were very different depending on which method was used. The PRA activity concluded that they chose 'power' and 'school' over the other development options whereas the interviews showed a preference for water. When results were cross-checked, power came out as a clear favourite with schools and water close behind, but roads and clinics were clearly considered undesirable. Finally, with regard to famine, very few of them went up the hill to work for aid during the famine, preferring to be self-sufficient. These findings will be elaborated on in the next four chapters. 


\section{Chapter 6}

\section{Findings on Transport}

\section{Introduction}

Nibgee is not a new village. There are records of its existence since the $13^{\text {th }}$ Century AD and life for its inhabitants has remained much the same until now [Appendix 5]. Even though outsiders tried to build a road, which every visitor imagined was the area's main problem, it is not yet usable. Among the many reasons for the road remaining unfinished is the unwillingness of the community to provide the free labour that is always expected from them.

The objective of this chapter is to discuss transport and its relevance to Nibgee village. The literature overwhelmingly confirms that transport is a catalyst for development [Chapter two]. In fact transport was dubbed the single most important factor in reducing or alleviating poverty and creating employment especially for rural communities (Fouracre 2001:5). However, the majority of Nibgee village's community argued that transport would not enhance their wellbeing; rather they felt it would spoil them socially as well as economically. Their arguments included their different cultural concept of the value of time; the social and cultural advantages of remaining isolated; the security inherent in being unreachable; and the negligible economic advantages of improved mobility.

\section{Transport and economy}

According to Wilson (1970:44), economic development is a direct and automatic consequence of the establishment of transport networks. He attributed this to increased specialization, improved political unity, attitudinal change, and price stability, but he admitted that negative effects were also possible. In Nibgee it is this potential for negative change and the unimportance of the positive possibilities that most influence their attitude towards roads.

The main motivating factor for the Nibgee people is not material wealth but spiritual purity and self-sufficiency. Yes, roads would be important for places where there are abundant raw materials to exploit, or cash-crops such as coffee, cacao or fruit to sell, however neither of these is present in Nibgee. They grow only what they eat, and sell 
only what they are forced to by necessity in order to get cash to buy other basic goods such as matches and salt. In Nibgee village all the people produce food crops. Life there is strictly subsistence. Farming is the means by which they have survived from pre-history until now. Those who poach charcoal illegally by burning trees in the surrounding bush that belongs to the government get cash easily. But even they do not want roads because this would mean that they could be more easily caught by the government.

The people of Nibgee resist economic pressure to specialise because they only want to be self-sufficient and live near a monastery. There is no place for individualistic greed in their communal society. If they have enough to live on, and some to put by, that is enough for them. While the road could be an important catalyst for change enabling the development of the area to sustain cash crops, Nibgee's people do not have the money, the opportunity or the inclination to change what they have been doing for generations. Inadequate credit facilities, also mentioned by Wilson (1970:44), are not relevant in Nibgee either. They do not want credit and their only savings schemes are increasing their herds of cattle and hoarding crops underground. An economic safety net is also provided by other villagers who all cooperate and help one another in times of trouble.

Fouracre (2001:3) stated that transport creates its own problems despite its economic advantages, by disrupting local social networks and exposing locals to the wider world. This aspect was clearly dominant in the minds of many interviewees. One man [OM-1] justified his fears of the consequences of improving road access to his village:

"It is this place that protected me from the Italian invasion. In time this place sheltered my son from being conscripted into forced military service during the Derg regime. I am sure that eventually it will save my grandchildren and all my descendents after that from any danger including unfair government obligations if Nibgee remains isolated as it is.”

The people of Nibgee are answerable only to the church and this arrangement is accepted by the local government who largely leaves them to administer themselves as they see fit. Improved transportation networks, therefore are desirable to neither party. As for other social networks that would be possible with greater mobility, they are seen as corrupting influences and are not wanted. According to the research data most Nibgeeans want their place to remain inaccessible as it is a shelter or safe-haven for them. A few participants did not even like infidel visitors to the church. 
Let alone visitors who come and visit them, they feel threatened by, and object to, any sort of progress. One young man [M5] said how the village people involved themselves in personal matters like selling things from home:

\footnotetext{
"At one time I opened a shop in my own house selling basic items which were useful for day-to-day life. The village elders, who came to my place and forced me to close my personal business, said that kids might be tempted to start to steal money to buy sweets and other stuff from the shop, which would corrupt their minds. This personal business was a one-time experience and, from that time onwards, life forced me to sell charcoal, which I am doing now.”
}

One economic benefit of transport mentioned by Edmonds (1998:2), the stabilization of price fluctuation, is therefore rendered obsolete as there are no local shops to charge extortionate prices. The villagers all take their produce to the market on foot or carried on donkeys and carry goods back the same way. Although this seems to outsiders to be a hard and laborious means of transport, they seem inured to it and they could not afford to run cars or use public transport even if there was a road. If the economic function of a road is to bring more cash into a community, it would not be economically viable in Nibgee as nothing brings in extra cash except the visiting pilgrims. Hence, in this valley, if they do succeed in building the transport infrastructure, it would only be effective two days per year to serve the outsiders who come to celebrate the féte of St Gabriel.

These biennial church celebration days have a double impact. On one hand, a few fortunate individuals make money out of those visitors by selling whatever they have for more money than they would get at the market. They get the chance to meet the buyers face-to-face rather than negotiating through brokers during market days up the hill. On the other hand, most of the villagers feed and chaperone all the guests for free and thereby lose the little they have. They habitually offer hospitality for free as they sympathise with the people who make an effort to visit the church. Therefore, although the road might help and bring economic benefits to some locals, it would disadvantage more, as more claimants to their generosity would be able to get there.

\section{Transport and time}


Transport is assumed by development experts to be a valuable time-conserving tool, a has proven that it is time-conserving and again, lead the area to prosperity (Gillespie 2001). sIn Nibgee village, however, even time is utilised at the discretion of the church and therefore does not have the same economic value that it would have for people who can work for themselves whenever they wish. The Nibgeeans' surplus produce, work days and market days are very limited as is their financial capacity to travel. Thus the benefits of roads do not apply to Nibgee.

Hilling (1996:157) expressed his concern about how people who live in isolated rural areas waste a lot of valuable production time cumbersomely carrying things to and from the market. It might follow, then, that a road to Nibgee would allow them to rush to market any time to buy or sell goods at their convenience. In practice, however, this could not apply to Nibgee. In Nibgee village, ultimate power is exercised by the church and no one is able to choose the days on which to work or when to rest. The many religious holidays, on which no one is allowed to work, are stipulated by the Nibgee monastery where the Coptic Orthodox doctrine is practised as it was prescribed in the Old Testament a long time ago. According to these religious obligations, more than half of the year is considered to be a holiday [see appendix 4] and no one is allowed to work on those days. If anyone is seen working on a day that is not allowed, a passer-by would stop him and say that he will bring a curse to the whole village. Thus the potential benefit of any road is immediately halved by the religious holidays.

Furthermore, market days are limited to twice a week. So even if the road was to be completed and accessibility improved, it would not be useful for Nibgee community. Firstly they could not go whenever they wanted to because there is only market twice a week. Secondly, as any farmer would attest, farm labour takes a lot of time; and as potential work time is already limited to half the year, they have to use their working days efficiently to the maximum extent possible. Their work on these permitted days is limited only by their oxen's ability to plough, the weather and available daylight. So, even if there was a daily market, they would not choose to go because they have too much work to do at home. Hence, "physical mobility in its context in terms of time use” (Hagerstrand 1987:13) is rendered useless as they would not travel most of the year.

Accepted wisdom says that mobility increases income generating potential which leads to “surplus capital which can be expended on essential services” (Fouracre 2001:5). But there are exceptions, like the people of Nibgee. For the Nibgeean it is not their increased 
effort or hard work that makes them prosper, rather they believe that will do well when the Holy Ghost blesses them. If they have enough to eat and feed their family as well as little to put by, they feel themselves blessed. Even if they could get to market more regularly, they could not spare enough food to trade any more than they already. Moreover, as previously noted, they do not want 'essential services' but prefer to manage independently. Although they understand the importance of transport, when they analyse the consequences of creating a road they feel that the result will jeopardise their independent life and encourage corruption, and so they prefer to remain immobile.

\section{Transport and social problems}

The consequence of limited mobility is not only economic but is also social. McDonagh (2006:356) mentioned that immobility affects people by preventing them from getting to places where there are other social groups to interact with. This is considered by most development proponents to be a negative aspect of isolation. There are however several social benefits to immobility. These include protection from corrupting influences, including pressure from modernisation, unhealthy competition and the plague of consumerism. The majority of Nibgeeans consider these negative consequences to outweigh the potential social benefits of the increased accessibility a road would bring for them.

Nibgee people in fact have an inherent distrust of outsiders that is difficult, if not impossible, to overcome. M5 came to the village when he was nine years of age and went to the church school, eventually becoming a deacon in the church. But, not being born there, he faced a lot of prejudice because of which he finally left the work in the church and resorted to selling charcoal to feed his family.

"Let alone outsiders who come for a day or two, even people who were not born in this place are always considered as outsiders who are hard to trust. Look! I did not get the land, which was already divided among them.”

Even though he had lived in Nibgee most of his life and had married one of their own community, he still described how the people are difficult to live with or work with. So it can be seen that the perceived social advantages of having a road would be totally unwelcome to Nibgee villagers as they do not want to know outsiders. 
For this community, where the monastery is the centre of the social world, even cigarette smoking is considered to be a terrible sin. The locals are well aware of the potential benefits of roads but do not want to expose their blessed place to the corrupt and unnecessary influences which would come with visitors. One expert theologian from Nibgee [M6] summed this attitude up very well:

"Yes. We know that roads are like eyesight. If more outsiders came our eyesight would be enhanced. But the partially completed road already allows us to carry sick people to the hospital, which is better than before. And, if the construction of this road was completed it would bring many advantages as the road builders first intended. Many outsiders would come to visit our pilgrimage and of course that would bring income to our area. However, Nibgee is a holy place and we do not like anyone to come just for fun and disrespect our customs, lifestyle and values. Our forefathers lived here without any problem only with the blessing of St Gabriel and we can continue as we are if we resist greed.”

Even without the road, pressures towards modernisation have already infiltrated this isolated community. This is evident in the pomp and grandeur of the church ceremonies and the individual competition over roofing materials. Although the locals are not interested in wearing modern or fashionable clothes or cosmetics, they strive to outdo each other in getting corrugated iron roofing sheets. So far the people of Nibgee have largely managed to avoid the plague of consumerism. However on market days they have begun to drink manufactured beer and eat luxury food such as raw meat.

\section{Transport and communication:}

One of the common assumptions about the benefits of transport development is that it enhances communication networks. Leinbach (1975:273), in his seminal publication, stated that effective communication systems were an essential prerequisite to sustaining prosperity. It is certain that most Sub-Saharan African countries, like many of the poor, suffer from immobility (Njenga and Davis 2003:235) and, in many parts of Africa unfortunate communities also suffer from lack of communication networks. In Nibgee itself, the only available communication technologies were a few simple battery radios. Apart from those, talking to each other, shouting up and down the valley and talking to people on their excursions to the market were their only forms of communication. As 
transport can strengthen interregional ties and enable the sharing of technical knowledge (Dnews 2006:2), linking Nibgee to other areas via improved transportation infrastructures, could be expected to help them by facilitating trade or promoting "inter-regional migration” (Cervero 1990:126) and the flow of information. However, the Nibgeeans village people are proud and happy in their own way and do not welcome outsiders to live there. They feel they are well-educated because of the church - and they do have theological knowledge, local knowledge and traditional knowledge. However, they deny modern ways of production, shun outside ideas, and in short have no desire to increase their own knowledge of the outside world or to share or disseminate knowledge about themselves.

Furthermore, there was no electricity down in Nibgee valley and it would take time and money to connect the power. Even if they wanted it, they could ill-afford the communication equipment or the ongoing costs of the power. Up the hill near Nibgee, the locals have power lines but no power in private homes as they cannot afford it. Nibgeeans do not have a culture of risk-taking or gambling so they are unlikely to try anything new unless its usefulness is guaranteed. This includes any communication technology including telephones.

The PRA dream mapping results show that the church people wished for electricity supply. They did this not for personal use, but to read books during church services. They did not mention cellphones, televisions or computers; but simply wanted to get away from using dim candles to read. Improved transport therefore, although it would bring the potential for improved communication networks via face-to-face contact with outsiders, would not bring this community modern communication devices as they are incapable of purchasing them or paying for the electricity to run them. Nibgeean life is strictly subsistence based and even radios and batteries are considered to be luxury items. Furthermore, as already discussed, they are not interested in increased contact with outsiders.

Results also showed that the Nibgee community is not yet prepared to have the road, and they do not believe having transport would save time and money. However the government would like to build the road, not to help the locals but possibly to control the valley. At the moment the only communication linked to the area is the telephone aerial erected at the top of the hill and the only times that access to the valley is important to the government is the yearly tax time and the five-yearly national election. In fact, the Nibgee 
people are happy to travel on foot to pay their own taxes and at voting time a booth was put down in the valley by the Election Commission.

\section{Conclusion}

This chapter discussed transport and its relevance to Nibgeeans with regard to economic aspects including time and employment; and social aspects including the communication linkages that transport brings. The Nibgeeans were happy without the road, as it was not viable for them economically. They do not have any exportable raw materials or enough food crops to make shipping from there to the market economically viable, nor are they potential buyers of any income-generating products. Their farming land is used exclusively to provide food for themselves, and they can not spare enough to sell at the market to make a road feasible for them. It is obvious that transport would save time; but time is not an issue Nibgeeans as they only work about half of the days in a year.

Nibgeeans do not want more contact with outsiders and prefer the social and cultural advantages of remaining isolated. The improved communication that would come as a direct result of transport would, from the Nibgeean perspective, only benefit the government as it would enable them to come down to harass and control them. It would let their haven place be invaded and the government would finally be able to control Nibgee. 


\section{Chapter 7}

\section{Findings on African states}

\section{Introduction}

In many parts of Africa today, there is no place for civil rights and there is widespread corruption in African politics. According to the 2007 Transparency International corruption index ${ }^{37}$, of the ten most corrupt countries in the world, the majority, and the worst are African states. Leaders permit their respective countries to be embezzled by their favoured friends, which makes a few extremely wealthy at the expense of the multitude of peasants and working class people (Chabal and Daloz 1999:37). African leaders, who tend to regard themselves as permanent kings, first protect their own interests and accumulate as much personal wealth as possible. Secondly, they perpetuate systems of nepotism and assist their colleagues and friends into positions of authority or help them gain wealth in order to keep their allegiance. Thirdly, they favour their own ethnic groups or traditional allies in any way they can. On the other hand many of them exile, oppress or torture their rivals or try to exterminate or expel any ethnic groups they consider a threat.

This inter-ethnic trouble is exacerbated by colonizers' cavalier demarcation of national boundaries. As previously noted in Chapter Two, national boundaries arbitrarily decided upon by colonial powers are still a major issue of contention, which continue to negatively affect Africa (Stedman and Lyons 2004:145). By their incidental location near national borders, separate ethnic groups were often lumped together, frequently under the power of mini-despots who used their power to back one group against another resulting in violence, civil wars or even genocide. Currently two countries which were formerly recognised for being among the most peaceful in East Africa, Kenya and Chad, are suffering from internal conflict because of political rivalry between ethnic groups ${ }^{38}$. As always, the ethnic conflicts, displacement and lack of unity resulting in part from these false-boundaries, have created cycles of violence, poverty and dependence.

Nibgee, on the other hand is a prime example of what is possible if people are left securely within their own ethnic groups, in a homogenous cultural and religious environment. They can live harmoniously and independently and need not suffer as those who were

\footnotetext{
37 The 2007 Transparency International Corruption Perceptions Index 12january2008.

38 All major news since 27 December2007 BBC on 13 January 2008 http://news.bbc.co.uk/2/hi/Africa /7186275.stm
} 
displaced suffered. False boundaries however are not the only reasons for displacement. In Ethiopia the Derg military government harassed, chased and executed those who opposed them. Those ethnic groups who the government suspected of being an imminent or potential danger to the regime were dispersed under the guise of 'resettlement' during the terrible famine of 1984-85 (Braun, Teklu et al. 1998:64). In fact this aggravated the famine as particularly the Tigrayan people were taken off farm-land and resettled on land that was not even farming land, or on unfamiliar farmland that they did not know how to farm (Hancock 1985). This reduced crop-production as well as breaking social ties. Some people also elected to move off their land to go to towns to try and get food. From there they were sent by the Derg government to rehabilitation centers and thence to different areas away from their homelands. This was also done to disrupt the social structures and decrease the cohesiveness of potential anti-government factions.

This sort of anti-civilian behaviour is typical of African governments, which do not respect civil society. Even when democracy is paid lip-service, or exists on paper, it rarely exists in reality. There is little transparency and the simple right to vote is seriously abused in Africa. A new phenomenon in African politics is the ability to vote freely, but often the results are rigged and the incumbent government rarely gives up power, regardless of the preferences of the people. For example, according to an unstructured interview with an official in the area, in the electorates surrounding Nibgee, all the votes in the 2005 general election went to the opposition; but the incumbent government kept power while the opposition was imprisoned in Addis Ababa. This, however, made little difference to the people of Nibgee who have not been interested in the government since the traditional leader who came from their ethnic group, Haille Selassie, was deposed in 1974. Not surprisingly, once the Amhara were forcibly disempowered in Ethiopia, the Nibgeeans tried to keep a low profile. They continue to pay their taxes on time to preclude confiscation and re-allotment of their land, and exercise their right to vote, but apart from that, have little interest in or knowledge of politics. In fact, as in many poor regions of Africa the only relationship between Nibgee and the government is tax. The government is equally happy to keep a distance from Nibgee. Possibly Nibgee is too poor to be of interest.

\section{Tax as the only interaction between state and civil society}

The only proxy relationship between the state in Africa and rural isolated people is taxation. As in any African country, paying a tax is an obligation in Ethiopia. No matter 
how poor people are, whatever the circumstance are, they must pay tax, which is hard for majority of the rural dwellers (Mariam 1986). Even during that horrific famine era of the 1980s the Nibgeeans paid their taxes. Since the Derg coup detats, Nibgee's people experienced the 'confiscation without compensation' rule. That taught them an unforgettable lesson. Therefore they pay their taxes promptly at the correct time. As a matter of fact, Nibgee people pay two taxes per year: one for government and another to the church.

The tax Nibgeeans pay to the government is progressive taxation based on the amount of land they have. A large family has more farming land than people who have less family to a maximum size of 10 hectares (Holden and Yohannes 2001:1-5). Tax is positively correlated to farm size but the maximum amount is 42 birr $^{39}$. Tax payment time is well known by all the farmers. They pay after selling crops or livestock at the market to get cash. Those who do not pay their tax on time might experience withdrawal of some formal services from the government office up the hill like concession papers for their admission to the hospital which is $70 \mathrm{~km}$ along the sealed road. Nor would they be allowed to get the government-issue fertilizer at a better price than normal market. However final consequence would be merciless even to the extent of losing their farming land.

Tithing to the church is also considered a second tax. This is paid regardless of the number of family members but the payment could be either in crops or money. Nibgeeans respect the church and regard tithing as a kind of rent for their immortal soul as they expect that their bodies will rest in the holy ground of the church after they die and their soul will go to heaven. What they do while they are on earth is immaterial if they are not simultaneously providing for their immortal spiritual residence. Tithing is an old family obligation and no one knows when it started, but none of the interviewees objected to the practice.

\section{The church as a non-political governing power in Ethiopia}

It is well known that most African States do not respect and are often hostile to civil society. But in Nibgee region it is different. The government does not interfere and leaves it to the church to manage the people. Government leaves them alone and disseminates information via the church. In Ethiopian history the only civilian group that was has had the power and opportunity to rule was the Coptic Orthodox Christian Church.

${ }^{39}$ Ethiopian currency. 
Before 1974, the Ethiopian kings' coronation ceremonies were reliant on the church and the relationship between the church and the crown was close. The calendar of Ethiopia is based on Coptic Orthodox Christianity. Heads of the churches had a lot of farming land and extra houses, but these were confiscated, along with the rest of the privately owned land in Ethiopia, in 1975. St Gabriel church of Nibgee is officially under the authority of the Head Church, which has much more influence than any other institute including the government.

Nibgee's church had a lot of land before 1974. During the revolution time all the land was confiscated and became property of the government. The socialist doctrine opposed religion but in the Ethiopian context the Derg understood that Coptic orthodox Christianity and Islam were deep rooted religions with the majority of Ethiopian believers and left them to practice the way it was. However, during the revolution followers of traditional beliefs and other Christian denominations such as Pentecostal charismatic churches were imprisoned and tortured and those churches were closed.

In Nibgee real and immediate power is exercised by the church. However there is no written constitution about this; rather it is an accepted convention. People listen to what the church says and do not bother about any other institutions.

\section{Forced Resettlement}

In Ethiopia there were many famines and shortages of foods in many of the isolated areas like Nibgee. The worst time of famine was 1984-5 during which hundreds of thousands Northern Ethiopian moved from their places in order to get help ((IDS)), 1983 \#171:165). However the people of Nibgee never went anywhere to ask for food and outsiders, including aid agencies and the government, never came to their rescue. The forced resettlements did not happen to Nibgee. Of course the people had a shortage of food but resisted it by selling their livestock and lending or sharing the profit thus gained with those who did not have enough.

During the famine, aid was distributed throughout Northern Ethiopia but not to Nibgee. This may have been because they did not come up and ask. Therefore they missed out on the donations but they also avoided forced resettlement. In the latter part of the famine, the government approached them with a work for food offer and some people accepted this. 
"As a response to devastating famine and environmental shocks, the Derg embarked on a massive program of resettlement involving millions of peasants" (Rahmato and Ayenew 2006:51). Forced resettlement was started to separate people who live in the North to discourage insurgency.

If we try to analyze the relationship between African states and Civil Society is always saddening to comprehend. Chapter Two discussed the gap between the ruler and the ruled. The majority of people in isolated places in rural communities are caught up in the daily struggle to survive. Unless they have raw materials that attract the attention of the government they are largely ignored. If they have such materials government representatives or agents visit them around election time. That is what happens in Nibgee. There was no government agent in the village before 2005. The paid school teacher has been there since the newly elementary school. However, a new Head Monk for Shifudge Gabriel church has recently been appointed by the Head Church of Ethiopia. He arrived in June 2007 and is still there.

Nibgee was well known in Ethiopia. Its monastery established a church school a long time ago, but modern schooling started with one voluntary villager. He had, himself, only been able to complete schooling up to grade nine as he couldn’t finish his high school due to the distance and affordability. In addition to that, as he was the first-born and a son, distance learning was not as option. Family responsibilities always came first. He is now member of the school committee. He mentioned that last year one lucky of his students went in to the university. It was then the aspiration of the villagers to send their students to his place came to existence.

If we considered the teachers as government officials in Nibgee village since 2006 they now number three. They do not have any involvement despite the school affair, which government is covering 30 percent and Nibgeeans 70 percent. There only responsibility is to look after their school and pupils while they are in school. The school has two flags to fly: the national flag and the regional flag, which is the sign that there is a school. Otherwise they do not have even a proper black board or any other properties to recognize that it is school. The school, tax and voting are the only links that Nibgee has with the government and the government is not interested in investing in roads or amenities because the valley people have no abundance of raw materials to export or cash crops to sell. 
During tax paying time no government agents come to their place so they have to go up to pay. They understand that if they do not pay their tax obligation they will lose their land, which is their means of earning a living. Mariam (1986:103) expressed the opinion that the state during the time of emperor Selassi and the Ethiopian majority: "state and its monarchy representing neither the interest of individuals nor of the community as a whole, but of the ruling class”. It is also the same at this very day.

The outsiders including the aid agencies knew that they were not welcome in Nibgee. In one instance on the top of the hill some New Age evangelists built a clinic and on the opening day at the inauguration speech the leader clearly stated that he was from other denomination and mentioned the different doctrines. All of sudden the villagers turned against the clinic and it was closed for several years and later on the donors handed it over to the local government and left the clinic. After this experience the aid agencies, never even went back to the village. Even so, most of Nibgee's people do not regard the donations as a blessing and always suspect the outsiders who come to offer them help.

"You can commit any crime outside and they will sympathise with you; but you cannot hide any crime committed in Nibgee. If you do they will hand you over to the police up the hill.” [M2]

Any visitors to Nibgee are considered to be suspect except the outsiders who come to take part in the church ceremonies. Nobody is welcome to do anything else, including any development work. In the history of Nibgee no aid agencies have tried to help them in any form. Let alone in the rest of Africa, in Ethiopia itself there are more than six hundred NGOs [Non-Governmental Organisations] and NNGOs [National Non-Governmental Organisations]. The aid agencies in Ethiopia are active mainly in the South.

\section{Conclusion}

This chapter discussed the proxy relationship Nibgeeans have with the government. African states typically repress vulnerable rural dwellers, but relatively Nibgeeans are free. However the government power still is exercised through, top-down approach at any instance, but the Nibgeeans prefer to be consulted and approached to any sort of development work in order to bring better result. 


\section{Chapter 8}

\section{Findings on participation}

\section{Introduction}

This chapter deals with the primary question of how members of the community of Nibgee regard their own development and perceive past development initiatives. This led to many other questions in an effort to analyse the Nibgeean attitude towards development, starting with what development means for the Nibgee people.

According to Anacleti (2002: 68) rural people form concepts of development based on how those developments actually affect them. They judge the merits and demerits of any exchange against their own unique standards that do not necessarily equate to those of the rest of the world. Nibgee people's attitudes towards development, therefore, are inevitably intertwined with the realities of their daily existence which are largely agricultural and horticultural. This in itself is not unusual, but the unique aspect of the Nibgeean culture is their dedication to the church. They weigh everything against the values of their religion. Nibgeeans believe that working hard on those permitted days [See appendix 4] and blessings from God will allow them to make the best of their lives.

Analysis of the interviews revealed that development, for the majority of Nibgee's villagers means self-determination and self-sufficiency. As one woman [F1] said, "Every neck carries its own head"; which means that one should take responsibility for one's own actions and take care of oneself. This does not mean, however that Nibgeeans do not help each other or fail to ask for help when they need it. They both receive help and reciprocate by helping others. However they prefer to do this exclusively within their own community and do not ask for outside help. Chambers (1997:xiv) defined development as 'good change', Nibgeeans were not interested in change for its own sake, preferring, rather, not to be hungry. Development for them means self-sustenance or being able to produce enough to meet the demands of every-day life.

\section{Participatory development in Nibgee.}

Most scholars agree that participation is an important tool for empowering the poor. The main difference between the scholars was not with the participatory aspect, but with 
whether the 'bottom up' approach is more beneficial to the vulnerable than the usual 'top down' approach. The intention of participation, as paraphrased by Gaventa (2004:33), is to facilitate the flow of knowledge and expertise, encourage wider involvement and cooperation, and broaden the power base throughout the process of development. In short this means that participation is neither the top-down approach by which outsiders decide on and control the whole development process barring the physical labour, nor the bottom-up approach, where the locals demand something from an outside authority, but a smooth collaboration between 'equalised' groups. Both parties are actively involved and ideally, marginalised, disempowered or voiceless people are given more opportunity to express their wants or needs, while those beneficent parties receive the benefit of local expertise (Cornwall 2000:11). This has never happened in outsider-initiated projects in Nibgee.

Nibgee's people have not been decision-makers in, or initiators of, any development project in their area. In Nibgee village the four major projects that have been started are at various stages and only one current project seems to have any chance of completion. The church, being built next to the current one, was nearing completion although the sponsor left before it was finished. It is expected to be completed in the near future, as Nibgeeans consider that is important for their immortal souls. The diesel flourmill, gifted to the church by one individual five years ago, was finished and is being used. However people complain about the price and choose to go up the hill where they pay less. The road construction, which began 18 years ago, is still unfinished, and a water project that was used before is now totally out of order. All four projects were initiated by the outsiders and there was no consultation prior to any of the projects. Nibgeeans have never been asked what they do or do not want. Typically, their only input was free labour given at the behest of the church. The work, especially the road construction, was not completed mainly because the locals were not interested what the outsiders had imposed on them.

Outsiders normally come to Nibgee twice a year to celebrate at Shifudge Gabriel church. Those are the only times many outsiders pay attention to Nibgee's people and the surroundings. Neither researcher nor government agent went to Nibgee to inquire whether they were deprived in any way, but the outsiders, who were not development professionals but who experienced the difficulty and the frustration of the narrow path, determined by themselves to build the road. Outsiders have always imposed their points of view regarding what the village lacked and dealt with the matter out of hand without prior consultation in any form except to extract the locals' free help on the projects. M3 
expressed the outsiders' aims:

"The outsiders did not care for the villagers. They tried to build the road for their own sake as the treacherous and narrow path made it impossible for them to pay their homage to Gabriel."

Mosse (2001:21) recognised that local knowledge is often manipulated by the researcher or the dominant group of the community, or in this case development agencies, to suit their own purposes. In Nibgee one man [M9] explained that outsiders had illegitimately raised money by mentioning the church's name to other Coptic Orthodox Churches in the area with a supporting story about the geographical position of Nibgee and requesting offerings by mentioning that they tried to build a road for them.

"We are a good source of income for these outsiders. They benefited with our geographical location and begged everywhere in the world by showing the area either on video or photos, as if we requested a road or other help. That was how they got money and they never disclosed this method of soliciting money on our behalf. They are selling us. God will punish them in His own time.”

If the outsiders had taken the time and consulted the locals, probably the villagers would have told them where to build or informed them that they did not want what was offered. As it is, the majority of Nibgeeans are fed up with those outsiders and disbelieve it when they say that they will do any development work for them. There are people who damaged their physical bodies while supporting the construction of the road, but no-one took them to the hospital or gave them any medicine such as pain killers. For Nibgeeans, development is just a way of using them or exposing them to unwanted confrontation with the general public, which they are better off without.

This drawing on the enormous knowledge base of the locals is a major benefit of the participatory way of development, and leads to better understanding of what they lack. Nibgee's homogenous community has lived there for generations. They know in what ways they are more deprived or better off than outsiders. However the outsiders did not give them a chance to be heard. In this village the outsiders came to inform them that they would make a road, church, flourmill and water pump. A few villagers trusted them and believed what they promised would be put in place but most people were cynical and tired 
of empty promises. M2 was the only one who mentioned that he doubted that any person would refuse when someone offered something they lacked even if they didn't want it, and concluded that that was what happened in their village. Further he confirmed that anything gifted by Coptic Orthodox followers was gladly accepted, but gifts from other denominations would not have been wanted even if they had been offered.

\begin{abstract}
"If someone wanted to help us in any form, no one would say "No, we do not want it," rather we would say, "Thanks". None of the people who came and promised us that they would do any of the above projects told us how much money they had, where they would get the money from or for that matter what they planned to do. Most of the time they only said that they had a lot of money and that they would be pleased to do something for St Gabriel. We never rejected them and we did not see the finished project until now. They played with our free labour too. The diesel flourmill was finished only because one benefactor who had the skill and money brought and erected it for us. The ownership of it is not yet clear. Some say it belongs to church and others to the community. "
\end{abstract}

This above response was not an isolated reaction. All the research methods used elicited the same response: they had not been consulted, there was a lack of transparency and inclusion and there was a general mood of unease about people coming to do anything in their place. According to Rahnema (2001:116), participation “could be either transitive or intransitive; either moral, amoral or immoral; either forced or free; either manipulative or spontaneous". In Nibgee, the only participation requested of the Nibgeeans was exploitative, manipulative, forced and self-interested.

There was only one man [M5] who had a markedly different opinion about the developers. He said metaphorically:

"Anyone who marries my mother is my father. I do not care who helps us as long us they give us what we are lacking. We are poor and we are not supposed to be picky. Rather we should accept whatever we are given and say 'thanks' to whoever offers their blessing hand.” 


\section{Participation and the vulnerable}

Participatory development techniques are meant to empower the weak and vulnerable allowing "women and marginalized people to determine choices in life and to influence the direction of change” (Moser 1989: 1815, cited in Nelson and Wright 1995:1). However Mopati, Prinsen and Mosse (2002:92; 2005:36) maintain that participatory development techniques perpetuate the marginalisation of the vulnerable because communities are not homogenous. According to their theory, there are chiefs and subordinates in any community. Although Nibgee village is formed from one ethnic group and one ancient religious practice, the church is definitely the powerful agent in the community. Despite this, they do not exercise their power outside their conventional bounds. Crawley (1998:25) bemoaned the gender power inequalities and argued that participation only exacerbated this problem. In the dream mapping activity, however, the Nibgee women confidently expressed their preferences even though these were contradictory to the mainstream church and men' opinions. This shows that they are powerful too. Everyone has dignity and respect. Even the outsider who was unhappy about not receiving land was free to express his views that he was marginalised. The people, however, did not care that he was marginalised. Nevertheless a culture of participation in local development is traditional in Nibgee. Not because a professional taught them how to do it, but because life in Nibgee forced them to live cooperatively.

In the Nibgee village there is no law as such. Everything is done according to doctrines that they received a long time ago. Nobody is allowed to change these customs. Even the Derg military socialist government left them to deal with their problems in their own way and the current government does likewise. Of course individuals might be bossed around by the priests, as the church is the only respected agency in the area. But the people allow this, not because the church is capable of forcing them, but to facilitate the smooth running of life in their spiritually-oriented community and for the good of their immortal souls. In the meantime, the church is not bothered about material benefits but spiritual enrichment.

\section{Conclusion}

This chapter has discussed development and participation with regard to Nibgee. The value of development is evaluated by local standards, which, in Nibgee village is strongly 
influenced by the church and their traditional lifestyle. Nibgeeans see development as self-determination and self-sufficiency, but not radical change. However there is growing resentment against outsiders as the Nibgeeans had never been consulted by outsiders for any of the development initiatives previously started in their village. The only outsiders that came to Nibgee were people who came to celebrate at St Gabriel church but because of past disappointments and lack of transparency with regard to the development initiatives they regard any outsiders with a suspicious eye and are not easy to associate with. This notwithstanding, participatory development, at least in terms of maintaining local control, is a longstanding reality in Nibgee and groups that are marginalised elsewhere, such as women, seem fully able to voice their opinions in Nibgee. 


\section{Chapter 9}

\section{Findings on famine}

\section{Introduction}

Famine can be defined as the local failure of production, allocation, or ability to purchase food, leading to mass deaths due to malnourishment and related diseases (Howe and Devereux 2004:355). This chapter will examine how Nibgee avoided experiencing famine and why they did not receive any aid during recent times of famine in wider Ethiopia.

Nibgee is situated in the Northern part of Shewa. Like other parts of Ethiopia this area is known for its historical susceptibility to food shortages (Hancock 1985:69). Edkins (2007) argues that famine is the result of human error. Yet the many contributing factors that have caused Ethiopian famine and food shortages - such as war, population growth and shortsighted government legislation - did not greatly affect Nibgee. Furthermore, Nibgee’s location and social conventions have acted as buffers against famine for generations.

\section{Nibgee and the Italian invasion}

Nibgee's isolation and inaccessibility have always protected it from invasion. During the Italian invasion of 1935-1941 the Italian flag waved in the capital city, Addis Ababa. Italy managed to control most of Ethiopia for five years but Nibgee remained relatively quiet throughout. None of the terrible battles or atrocities that Ethiopia passed through touched Nibgee directly. Only once during the Italian invasion did Italy try to overtake Nibgee. They failed and never came back. One elderly man [M8] reflected on how Nibgee survived during the Italian invasion:

"In those days no one expected that it was an area for humans as all the treacherous cliffs were bushy and dangerous gorillas also lived there. It looked like a place for monkeys to hop up and down, not a place for humans to walk. Thus it was easy to ambush them. We waited in hidden spots on the hillside and it was easy to create landslides of rocks onto them from many different areas. This really helped us to attack our enemies. The Italians tried one day and left immediately, setting fire to the bush, but it did not go any further and did not damage our haven.” 
In fact, Nibgee provided shelter to outsiders as well as locals. During the Italian invasion many insurgents sought refuge there, and brought money stolen from the Italians as well as armaments and food crops. The insurgents stayed in the bush or in the houses of the locals. The Nibgee villagers also went up the hill and brought back goods on their behalf. There were no food problems then.

\section{Derg time and Nibgee}

During the Derg era, Ethiopia passed through at least three major wars: against Eritrea, against independence fighters and against Somalia. As in the time of the Italian invasion, insurgents seeking shelter in Nibgee brought stolen or hoarded wealth. Nibgee passively opposed the Derg regime as they had the Italians by hiding insurgents. Although the Derg socialist government erected a telephone aerial on top of the hill in order to be able to quickly suppress any mobilisation of forces from Nibgee, they never sent troops down. During this era many atrocities were perpetrated most of the country, but not in some sheltered or isolated places including Nibgee.

According to Devereux (2007:51), war also contributes to famine by removing men through military conscription who would otherwise be growing food. Nibgeeans managed to avoid compulsory conscription because nobody could find them. Even if the government agents had come down the hill to get them, the Nibgeeans would have hidden in the bush when they saw them coming. But, in fact, no-one came down. A few people went up and joined military however, including priest [M9].

Other government legislation which was easy to enforce in the Highlands also barely affected Nibgee. During the Derg era, when all extra houses and privately owned land became the property of the government, the Derg forced country dwellers to resettle in areas where the government could control them. This was in fact to disrupt the social networks of a particular group of people the Derg government feared may cause an uprising but was publicised as a humanitarian response to "devastating famine and environmental shocks" (Rahmato and Ayenew 2006:51). However, land is not the same everywhere and resettlement had an enormous effect on farmers who need pasture for their herds and arable land for their survival (Devereux 2003:19) and instead it had the result of prolonging or worsening the famine. 
Government tax impositions also created real financial hardships and affected the farmers ability to purchase the things they needed to farm effectively (Mariam 1986). As intended compulsory resettlement their social networks of support were disrupted and they were forced to start from scratch again: building houses, learning about the idiosyncrasies of the land and the culture of the local people in their new areas, and dealing with local resentment. Because their ability to grow the crops they needed for survival and for sale was seriously impeded, widespread hunger was the result. During times of starvation people were even forced to sell the things they needed to farm.

The Nibgeeans, however, were not so disrupted by the change, as they only had one house each, and there was no renting. The land redistribution did affect them, but as local land was all redistributed to local people this was not problematic. They could continue to farm the land with which they were familiar in their traditional ways unlike those poor unfortunate farmers up the hill whose displacement took them to unfamiliar land that they did not know how to farm. While the Highlanders were receiving aid the Nibgeeans continued to farm to provide for their own needs. The bush also had a lot to offer in the way of food and supplies to anyone who knew how to find it. Deer were plentiful and there were many edible fruits, especially prickly cacti. This and other forage helped the Nibgeeans to supplement their diets and survive.

\section{Farming style}

Nibgee's people have managed to scratch a living out of their inhospitable surroundings for centuries using the same traditional methods. Now, however, a growing population is creating pressure on the limited farm land available and plots are getting smaller. That is why they have begun to experiment with tilling the steeper hillsides and using more fertiliser. They are also continuing to employ the traditional methods of resting different parts of their fields every season and rotating their crops to prevent the soil from getting depleted.

The Nibgeeans have begun to recognise the need to modernize agricultural techniques to maximize soil productivity so have started using two types of fertilizer: urea and dap on their Teff ${ }^{40}$ crops. But for the rest, they continue to use cow and goat manure and ashes. Their traditional food crops: Teff, wheat, beans, peas and onions grow in marginal soil;

${ }^{40}$ Ethiopian staple food. 
and the type of humped cattle they keep survive on little food and water. Their goats also forage amongst rough grazing in areas too bushy or steep to plough.

The Nibgeeans plough using oxen on the easier slopes, and plough by hand the land that is too steep for their oxen. They maximize the productivity of their crops and cattle by harvesting the stems as well as the grains and feeding this roughage mainly to the oxen. Cows are not as well fed as they do not have to work in the fields but are used mainly for breeding and milk production. Cows' milk is used for drinking, cheese and butter. Cows and male goats, and barren nanny goats are used for meat, while the male oxen are used to pull ploughs.

The Nibgeeans consume cattle meat mainly as salvage, meaning if they see that a cow is sick or old or no longer able to work, they slaughter it and share the meat with each other. If an animal falls from a cliff, everybody rushes to kill it before it dies to fulfill their religious obligation ${ }^{41}$ to say the name of the Father, the Son and the Holy Spirit while slaughtering the animal to be eaten. The locals share the burden and the blessing of the lost animal. Most people have more than one cow so they can still get milk products and breed more oxen. All milk products are made and consumed by the owners' family, which is remarkable as they share almost everything else. No dairy products are sold, so the loss of a cow is not as terrible a financial burden as the loss of an ox which tills the soil.

The Nibgeeans till soil that looks impossibly rocky to an outside observer. But for Nibgeeans, the places where the rocks that were supposedly bad for the harvests lie most thickly on the ground are the best for farming. Each time they plough, the rocks twist from one position to another which gives the covered ground time to rest for that season ensuring it would be ready to sow the next season. This gives them an advantage over meadows without rocks, as those occasionally need to lie fallow for one whole season for the sake of the ground. This makes Nibgeeans feel proud and blessed for having that rocky land.

Whatever crops they produce, the Nibgeeans keep some back to plant the next year and hoard some in their compounds to eat later. One old man, [M8] recounted how the Nibgeeans lost faith in buying wheat from unknown markets when they noticed that some seeds bought in the market were terminated or 'unblessed' and did not germinate. From

${ }^{41}$ In Coptic Orthodox they eat only halal meat. 
that time they understood that it was better to always keep seeds from Nibgeean crops to be assured of a good harvest the following year.

\section{Cooperation}

"The one who eats alone will die alone". This traditional Ethiopian adage, from the interview with a young man in Nibgee [M1], sums up how the community supports its own members as a collective. In Nibgee, even if you want to live entirely by your own efforts it is almost impossible; the elements, the land, time and the amount of work to be done all conspire against it. Social gatherings such as funerals, weddings are also of paramount importance in this communally based society. Attendance is conventional, but so ingrained is the habit that it may as well be compulsory. For example, if someone dies, all members of the community participate in the funeral preparations. Jobs are delegated for every stage of proceedings from washing the dead body and funeral arranging to food preparation for those who come to bury the dead. They cooperate with each other as it would be hard to dig a grave by oneself.

If it was remembered that you did not attend someone else's funeral, when your turn came to die, no one would bury you. There is another saying in Nibgee: "Nugg Bennae”, which translates: "Tomorrow is my turn."

Individual problems such as sickness, old age or farming, are also regarded as communal problems and are never left to the responsibility of any one person. Old people are kept in the house and fed and helped in every way by their closest relatives. Children have a particular responsibility to care for their elderly parents. The old people, for their part are valued as good advisors about farming and life in general, and they enjoy going to the church to share stories and pray. The sick are treated by local medicine which is commonly known by the local people, and they rarely go to hospital. Their dismissive attitude towards clinics showed up in the interviews and the PRA results. Nobody wanted clinics [See Figures 7]. When they are well, they do not want to think about the possibility of being sick. When they are sick they use their own herbal remedies that are administered by the family. It is only when these fail that they go to the hospital in Addis Ababa as a last resort. Elsewhere in Ethiopia witchdoctors and soothsayers may be consulted, but around the monastery in Nibgee they may kill anyone like that. If the next of kin needs help to carry the sick person, they ask another local but this is a rare 


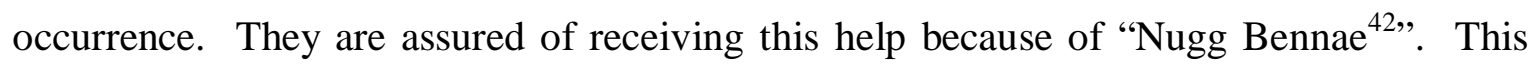
also applies to farming. It is impossible to push a plough alone so each person helps the other and receives help in return. If one local lends someone else their ox for ploughing it is a big help.

As mentioned above, when a cow or ox falls from the cliff, the community helps out as well. They band together to divide the meat from the animal that fell and then help the individual whose animal it was by buying part of the meat, in a form of unofficial insurance. Even if the villagers have no money at the time, they give an oral promise to pay so that the family who lost the cow will eventually recover at least two thirds of the price of the animal, which is at least better than nothing. In this place with no freezers, meat is preserved as jerky by slicing it into small strips, marinating it in salt and chilli and hanging it to dry in the house. In this way the meat can stay edible indefinitely.

\section{Hoarding against hard times}

Nibgeeans also preserve grain by keeping it dry. During the reign of the military government, hoarding was against the law and those caught doing it would be shot. The Derg used to execute hoarders who they blamed for creating false inflation in the market. Hence, Nibgee's people were naturally very secretive about it. The 1984-85 famine was the worst ever to hit Ethiopia. Villagers in many other parts of Ethiopia were forced to leave their place in order to survive, but this never happened to Nibgeeans. Most of the people attributed this to being blessed by God. However the reality was that hoarding crops, lending and sharing were common in this community as survival strategies at the time. When they have excess money they re-invest it in crops and fertilizer and bury the excess crops. These secret caches were what sustained them during the famine era.

Nibgee is a homogeneous society and almost everybody keeps their excess crops buried in the house. Normally crops are kept in the back yard in a small shed, but during the famine era the Nibgee people buried their crops secretly to conserve them. The Nibgee people do not save their money in banks. Their savings scheme is based on crops and herds. They always expect the worst and have a saying "Yemetalen tetesh aymetamen yaszi”, which means 'Hope for the best, but plan for the worst and expect the unexpected'. With this stoical philosophy, cooperation, canny farming practices and looking after each other have

42 Tomorrow is my turn. 
allowed Nibgee to remain in food at all times. Hence the ill-effects of famine mentioned by Howe and Devereux (2004) were not experienced.

\section{Outside help}

Almost all northern Ethiopians received some form of support during the 1984-5 famine (Hancock 1985:72), and a few parts of Ethiopia are still receiving aid today. Without international and national humanitarian aid many rural people would not have coped with the famine. Even with all the support hundreds of thousands of people died. Many blame the heads of government or the democratic process of the country for causing famine through lack of awareness and preparedness (Devereux and Tiba 2007: 163). In Nibgee however, there were no aid agencies or government representatives at work.

The official up the hill explained:

'The Nibgee people resisted the famine by bulking up their diets with cheap locally grown or wild supplements. Those who finished their crops sold their cattle but that was the only deal we knew about from the Nibgeeans. Up the hill, let alone for the 1984-5 famine, in 1998 they were still being supported by the government."

He further explained that the geographical position of Nibgee made the people strong and independent. A few young, fit villagers went up during the famine and participated in the 'food for work' program and received cooking oil and wheat. This 'food for work' aid program was ironically designed to benefit the strong, not the weak. Those who were too weak to go up the hill to work would miss out. No-one came down the hill to check, ask or inform them, and they on the other hand did not ask either. Instead they took the drastic measure of selling their cattle. Of the twenty-one interviewees who answered the question about aid, eighteen did not go up to work for food because they did not want to go and one was too young then. They said that they did not want to beg, preferring to pray to God. Perhaps they were too proud. When interview results were analysed according to demographic groups [See Figure 1], older people and church people were more likely to rank themselves as equal rather than superior and none of them rated themselves as inferior to Highlanders. Perhaps they were just more diplomatic. On the other hand, the women, the young and the laymen were not too tactful to say that they felt superior to the people living in the highlands. And the few who said they were inferior felt disadvantaged by their landscape and isolation. The researcher's impression, though was that most 
Nibgeeans felt superior [See Figure 2]. This pride was probably what prevented them from asking for help and perhaps they were resigned to their fate.

Women, who spent a large part of their lives in horticultural pursuits and have the responsibility of preparing and cooking food, saw anything that enabled them to grow better or more crops as being of equal importance to independence. Women therefore identified as development those things to do with feeding themselves and their families. Women are also the ones who carry water. The source for drinking water is a spring, which is far away and difficult to access, especially for the old. Conversely Church people did not prioritise water. They are all men and whatever they need is brought to them when they order it. Schools were the second most popular choice for women. It is possible that they want their children to have the opportunity to escape the yoke of the burdensome life that they have. It was striking that the women overwhelmingly chose schools to benefit their children while their own lives are so hard. They work in the house and they work in the fields so the burden is double for them. This generous female attitude contrasted glaringly with the men's particularly in the concept of development labelled 'quality of life'. No women mentioned improved quality of life as an important aspect of development. The people who cited Improved Quality of life were either old or young laymen but no females or church people chose this hedonistic option [See Figure $3]$.

The old people who are really close to the church wanted to be independent and even in their old age they did not want to give up their freedom. They know that aid agencies come not only to help but to promote their own interests or propagate their religion. Their concept of independence was closely tied to the ability to grow enough food. The old had no interest in schools at all, probably because their children are all adults or because they did not go to school themselves and did not care about 'better opportunities'. In fact no one really cared about 'better opportunities’ because they are happy as they are.

Maybe they were happy to make do with what they had during the famine. In order to keep their independence, the Nibgeeans managed to remain self-sufficient. Even in their extremely difficult times they just tightened their belts and made do with less. After all, it is a monastery in which people already lived a subsistence life rather than a luxurious life by choice. As the local saying goes, "Ledgena houdde endasayute neow", which means, 'Children and the stomach do what you teach them'. In practical terms this means that your body adjusts to survive on what is made available to it. This is how the Nibgeeans 
survived the famines.

\section{Conclusion}

This chapter discussed how the Nibgeeans survived during the terrible times of war and famine that crippled wider Ethiopia. It briefly examined how they fed themselves and remained independent by using traditional farming methods, and how cooperative forms of social security helped them. It also noted how their rough topography protected them from any atrocities, invasions, outside interference and famine. It is certain that nobody came to assist them during the famine and did not receive aid, but they did not care about this because they would have been too proud to accept it anyway. If they had been really hungry they would have gone out - as others were forced to go out from their places - but they managed with what they had. 


\section{Chapter 10}

\section{Conclusion}

\section{Introduction}

This study began with the hypothesis that the people of Nibgee needed a road. It examined the historical, geographical, social, cultural and political factors affecting Nibgee and the attitudes and desires of the Nibgeeans with regard to development. It finishes with the conclusion that the people of Nibgee are generally happy as they are and do not need a road. What the majority of them do want is a new school, electrical supply, and, for the old people, easier access to water.

Chapter One outlined what inspired the researcher to write about Nibgee village and the primary and secondary questions were set up. What confounded him most at the beginning was why the people of Nibgee chose to stay in an inhospitable, unattractive and inconvenient place. The questions were geared towards finding out what forced the Nibgeeans to stay there; and what their attitude was to outsiders, to development and particularly to the road.

In order to fully understand the theoretical background to the research, Chapters Two and Three examined the view that transport is the catalyst for other forms of infrastructure and is the key to development for isolated rural communities. The relationship between African states and civil societies was examined. It defined development generally, and participatory development specifically; noting the importance of local definitions of development. Finally, the theoretical causes of famine were discussed concluding that famine was largely attributable to human error. Chapter Three briefly examined Ethiopian history.

To find the answers to the primary and secondary questions, Chapter Four of the thesis outlined four research methodologies and applied them to the field work.

Chapters Five to Nine were the results and discussions based on what was discovered from the fieldwork. The results were triangulated with the background theories and summarized. However the observation map and personal conversations, including interviews, brought to light a different angle to see exactly what Nibgeeans stood in need 
of. In Nibgee there was no consensus on what they were lacking, with power, schools and water each being similarly attractive to Nibgeeans. But the hypothesized fundamental problem that the researcher expected, 'transport,' was not considered a major problem by this community. Nor were clinics at all desirable to Nibgeeans.

The initial aim of this research was to investigate how the isolated people of Nibgee suffered because of immobility; how they regarded their own development; how they compared themselves with the people in wider Ethiopia; and how they survived famine without any support. It was expected that the research would confirm the importance of roads for this isolated community and prove how underprivileged they were. However, the findings show not only that they consider themselves very privileged to live where they do, but also that their lack of mobility was less a detriment than a deliberate choice. People from Nibgee are renowned for their reticence and the steady reserve they maintain towards outsiders. This has kept them safe and helped them to lead life in their own way for centuries. Hence, despite their awareness of the benefits of roads, the Nibgeeans are not interested in roads or the increased contact with the outside world that roads would bring.

It is to be hoped that this research will contribute to a deeper understanding of Nibgeeans, their lifestyle and their perspectives on development. They have sound reasons for not wanting roads. They have their own skills and strategies to cope during times of famine that have enabled them to avoid disruption and which meant they never needed to ask for help even during the troubled years when wider Ethiopia starved. Their attitude towards outsiders, their lack of resources for the government to exploit, and their typically oneway link to the government in the form of tax, were discovered to be the reasons why nobody ever came to help them. Their concepts of development comprised things that enhanced their current mode of existence without substantially altering it. Rather than wanting to change or be changed, they were happy with their conventional ways of ruling themselves and dealing with their own problems with their own reasoning that have enabled the Nibgeeans to remain relatively peacefully in that deep steep valley while avoiding many of the pitfalls that beset the major part of Ethiopia.

It is argued that participation at all stages of development is of paramount importance to enlisting local support. This has been patently absent in any previous development initiatives in Nibgee. Notwithstanding the possible sympathy of the outsiders for the community, without understanding the core issues pertinent to the community it is 
unlikely that any good will come of their efforts to improve things for the locals. In fact the locals feel that the outsiders only want to help for their own benefit and merely took advantage of them. The Nibgee community resented the outsiders' lack of transparency and consultation. Hence outsiders who tried to help failed time and again to produce lasting results simply because they did not consult with the locals or take the time to get to know them. Lack of proper consultation is truly a fundamental cause of misunderstanding.

Central to any future development in Nibgee should be local ownership and direction of and involvement in all stages of the development process. Nibgeeans know best what Nibgeeans need so their involvement in choosing the development project is obviously important. Most importantly, their religious practices and ways of life should be respected as they do not want to hear anything about alternative theologies. They would consider it to be and impertinent imposition and may react with hostility. If fundraising and planning for any development initiative is transparent and open, Nibgeeans are far more likely to accept it. If their involvement in the labour is required, they should be remunerated accordingly, as their work time is very limited and they need to use it to work on their farms. Developers should either pay them good money that would compensate them for the year that their farming income would be disrupted, or leave them alone and do not request their help. Without their goodwill, any development initiative is doomed, so enlisting their full support is vital for the ongoing use and maintenance of any resource. If they do not like it or believe in it or feel they are the owner of it they will let it break down for want of repair.

\section{Transport and development}

This thesis began with complaints about the topography, the isolation, and the lifestyle. Research was instigated with the intention of 'fixing' the locals whose continued existence in Nibgee was a source of wonder and pity. But these perceptions and good intentions were ill-founded. Their lifestyle, although physically arduous, is healthy. Transport was one of the major development initiatives expected to have eased the burden of life. But the people of Nibgee do not feel burdened by walking as it is just a part of what they have always done. They are healthy, fit and strong and most of them seem to live to a ripe old age, so walking for them is simple and easy. Besides, time is not a major factor to them as they are stress free. The importance of the road is mainly felt by outsiders and the Nibgeean perception is that the government would use it to observe or control them. The 
Nibgeeans want their place to be isolated for many reasons and they are happy as they are.

\section{Isolation as a deliberate strategy}

The thesis found that for Nibgee, being isolated is the best policy for survival in many aspects. Nibgeeans meet people on their own terms and their geographical positioning does not allow others to come easily. It has helped them during times of war when the majority of Ethiopians faced atrocities. In fact their place harboured insurgents, who brought crops and ammunition for them. During the recent famine in Ethiopia, their place had a lot to offer including deer and many tropical fruits. Being in the area of a monastery, they have received many lessons on how to suffer and serve God. In the hungry times of famine they just ate less and shared what they had with those who had less than enough. They shared their burdens with each other but never begged anything from outsiders. Their habit of storing food against times of need, their sustainable farming practices and cooperative existence are pattern cards for the rest of the world to live by.

\section{The importance of culture}

Not being hungry is the primary aim for the Nibgee community and to feed their own families is their primary obligation. Any individual calamity is always considered to be the problem of the whole community and everyone tries to repair the damage sustained in the incident in accordance with tradition. They are from one culture and ethnic group, which helps them to cooperate and respect each other. The people themselves are their own legislators, judiciaries and authorities. Modern technologies are only accepted if the locals consider that they are important for them; otherwise they do not have any place in Nibgee even if one of the community members wants something for his personal use. They believe that the outside influences would bring their own ill effects.

In Nibgee village the ultimate power is exercised by the church and more than half the days of the year are considered to be holy days. Their lives are circumscribed by convention and they live in a Christian way as laid down in the Old Testament. In fact, never having been displaced, divided or forced to assimilate anyone of a different religious or ethnic background, the people of Nibgee are secure in their monastic outlook and traditional way of life. The workload they have on working days is heavy, but they cooperate in their own way. They delegate the workload to everybody in the village and reciprocate. Their surroundings preclude individualistic attitudes even if they wanted to 
behave otherwise. But, although arduous, life in Nibgee is simple and people live to facilitate their after-life. Therefore, most of them do not want to receive anything from anyone from outside their own denomination. Greed is not part of their philosophy.

\section{Suggestions for future research}

It has been widely argued that instead of imposing development initiatives according to preconceived ideas, outsiders must develop close relationships with the communities with whom they work. They must recognize the community's unique histories and internal dynamics. Furthermore, they must work in a manner that builds people's faith, across the lines of division, in a shared future. This is equally important for researchers in such types of isolated communities.

This research disregarded people under the age of eighteen, but they were the highest users of the path. Any future research should attempt to capture the opinions of this large group. Moreover, the absence of old people and low ratio of females to males also made the results of this activity somewhat suspect. As only were five women interviewed, it is impossible to accurately extrapolate these results to the wider community. Organisers of any similar activity in the future should account for this in their planning to equalise numbers. But, even if numbers were equal, sometimes women's opinions were masked in interviews where others were present and, as it was a monastery, it was also difficult for the male interviewer to talk to women on a one-to-one basis. He was reluctant to meet with women unaccompanied by their male kin as he did not like to create any ambiguity, or risk creating a barrier to the entire research. As Spencer (2004:207) said, it is very important to "cultivate your reputation". It would be better to have a female researcher to interview the women.

In fact there were too few interviews altogether to extrapolate results with any authority. The people took a long time to open up and were not frank enough to give answers. Perhaps on a second or third visit they would trust the interviewer more or maybe somebody else should go there as a student of theology and from insights from living there more than 1 or 2 years and could conduct the research instead.

People in Nibgee are used to doing things cooperatively and their true feelings may have been masked in the PRA appraisal by 'peer-pressure'. The consensus of the priests 
regarding power, for example, was possibly exaggerated and had the effect of skewing the results of the Dream Mapping activity. Thus the interviews may have given a more accurate representation of their true preferences. 


\section{Appendixes}

Appendix -1-

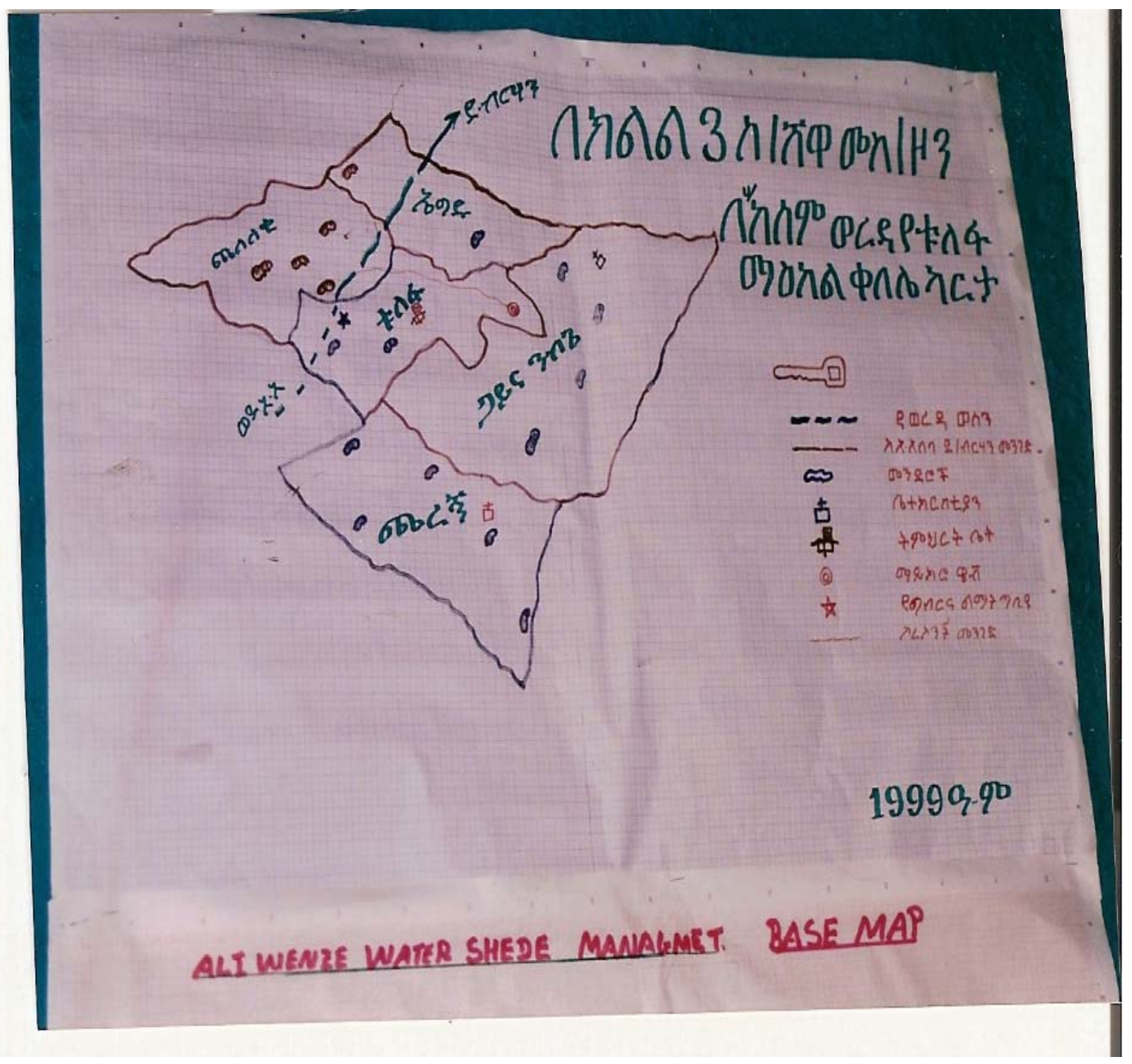




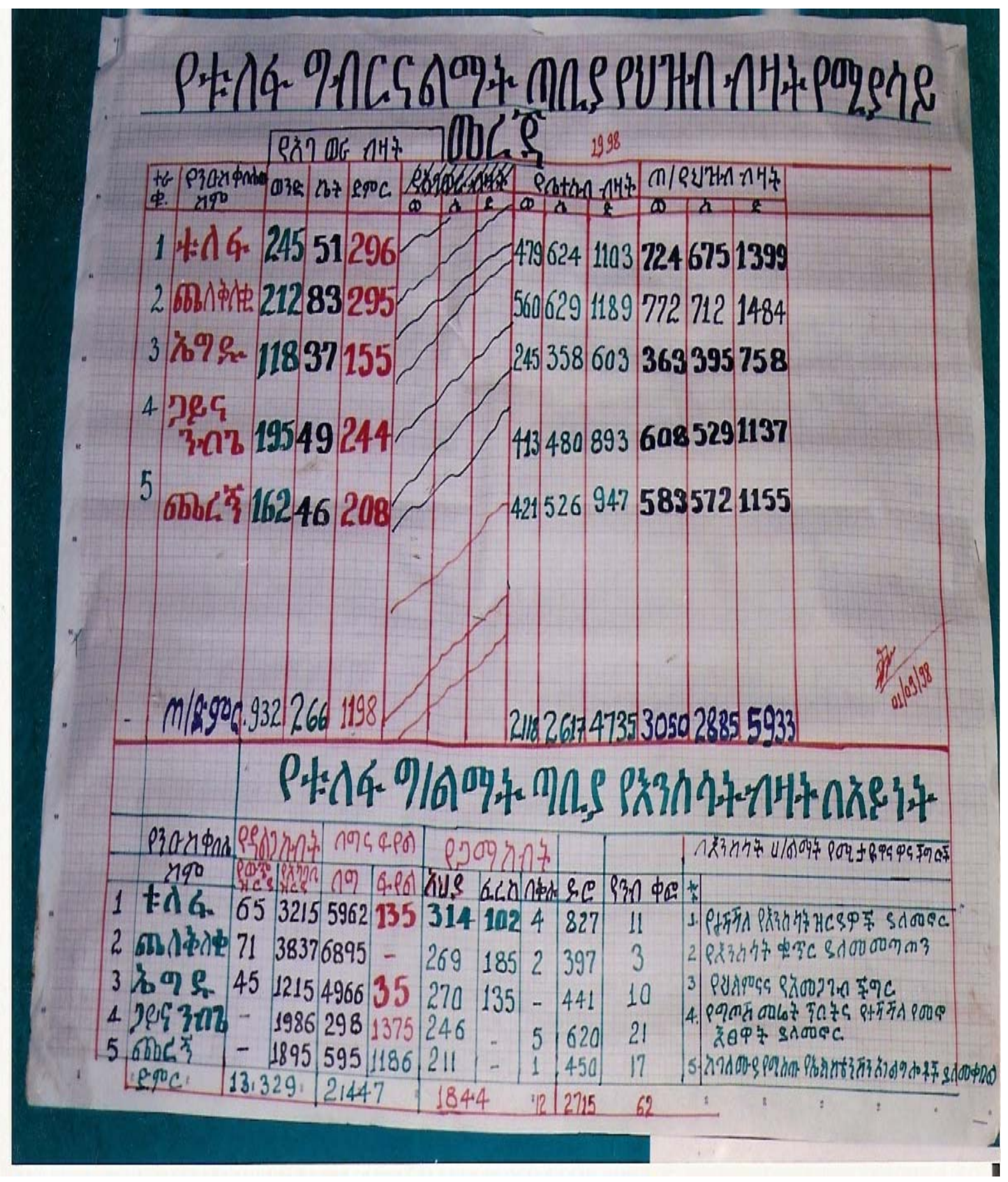




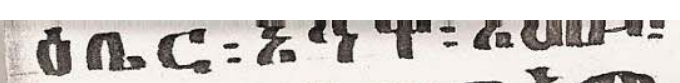

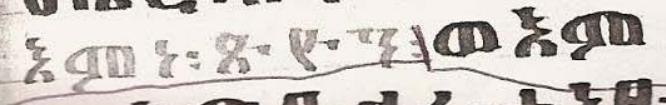

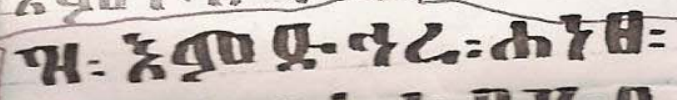

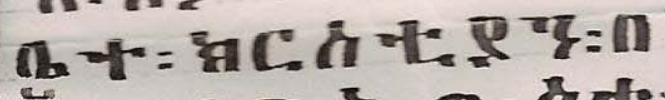

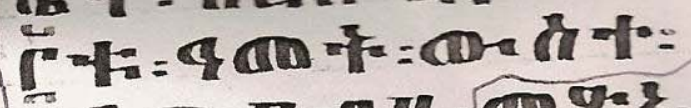

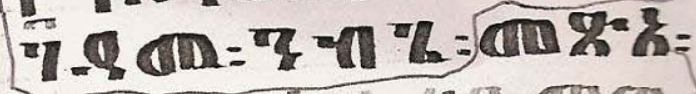

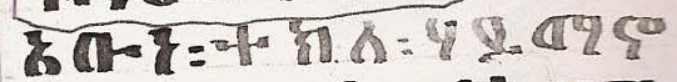

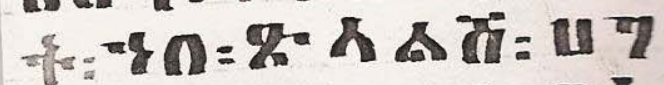

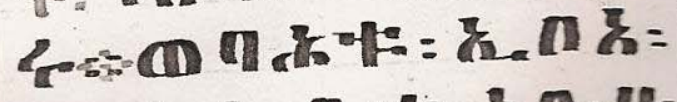

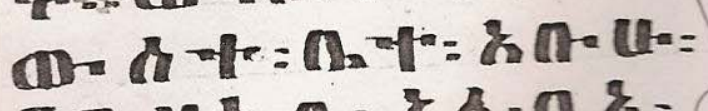
\%

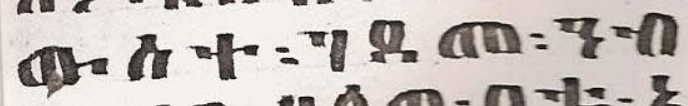

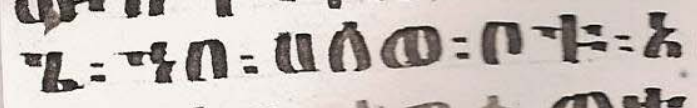

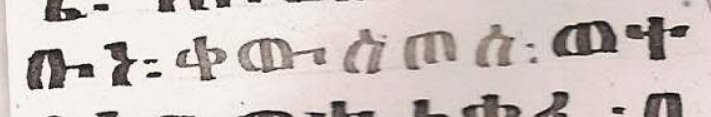

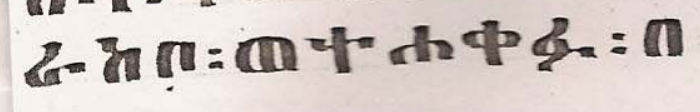

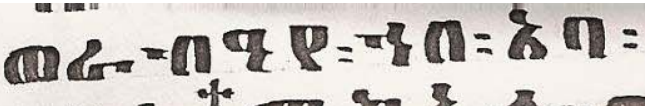
ก \%

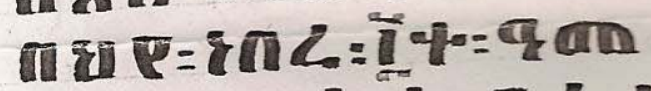

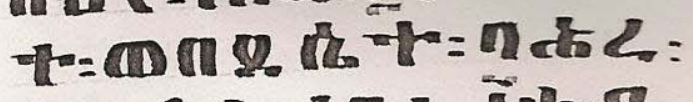

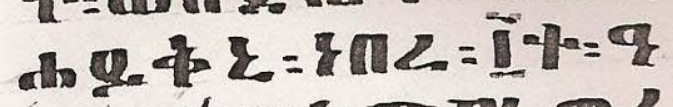
ati -

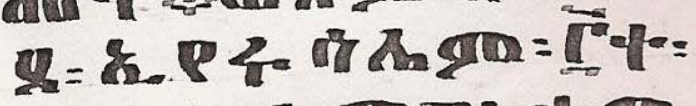

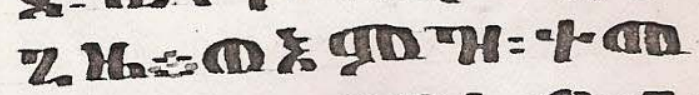

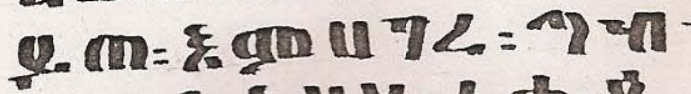

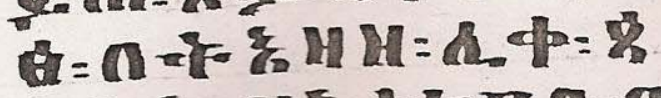

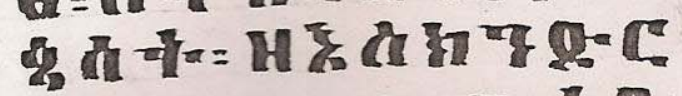

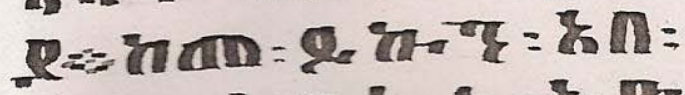

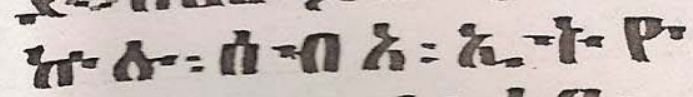

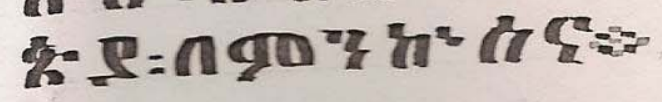

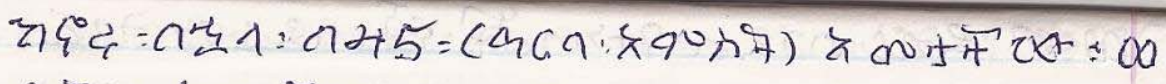

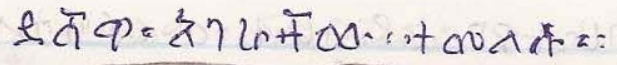

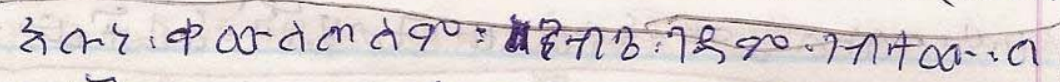

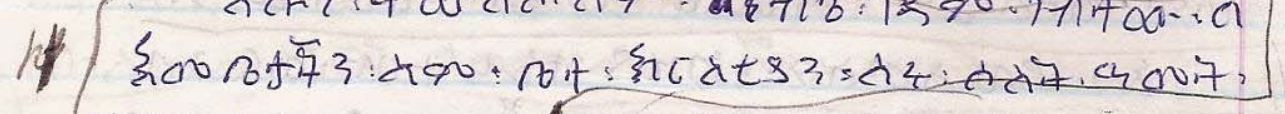

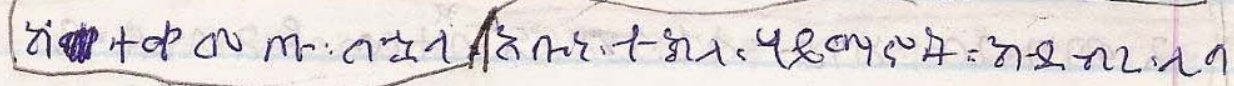

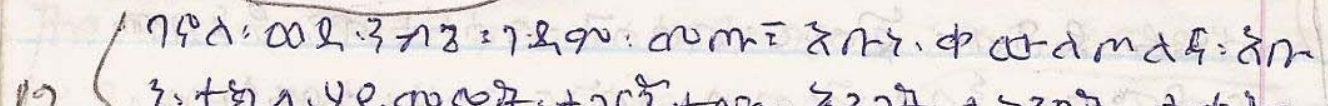

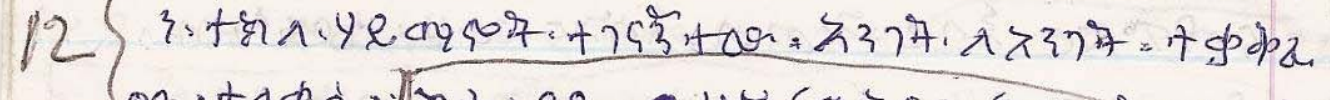

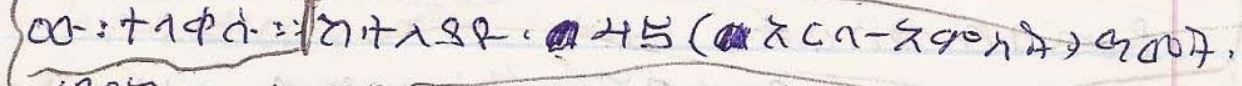

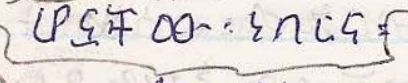

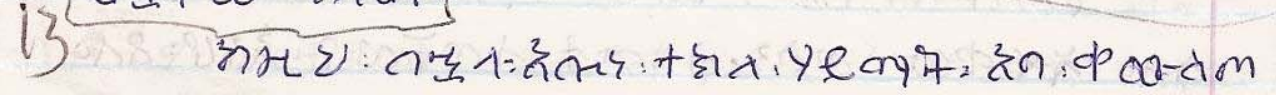

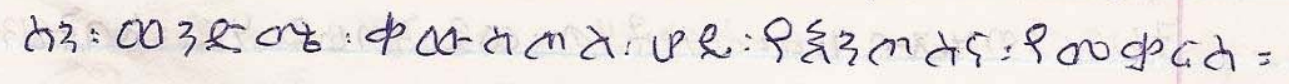




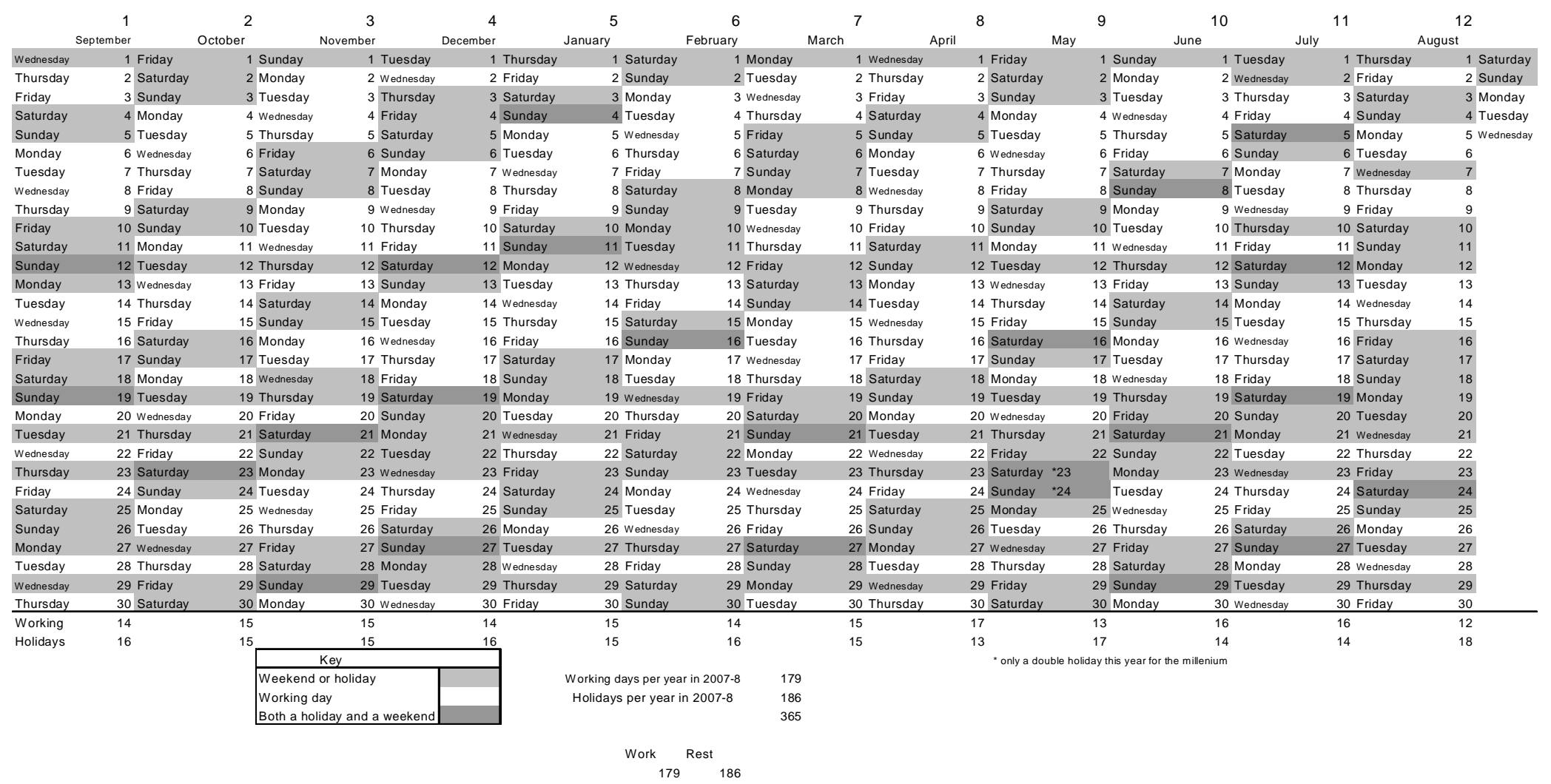




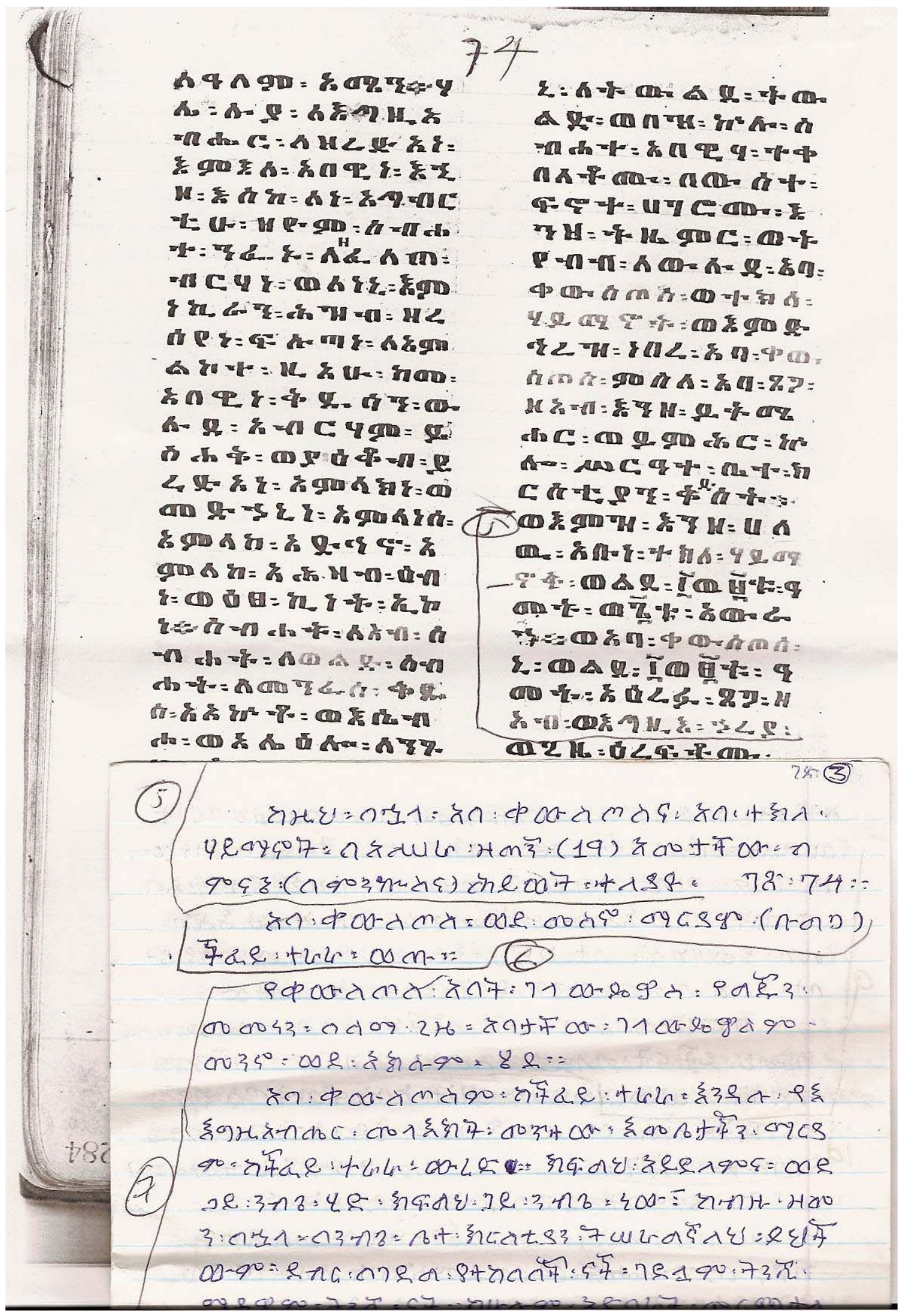




\section{Figures}

Figure 1 : Self-perception when compared with the Highlanders ...................................54

Figure 2: Self-Perception when compared with Highlanders [interviews]........................54

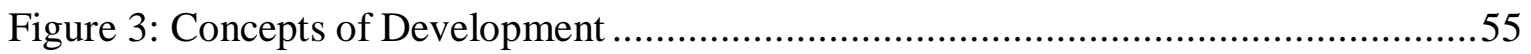

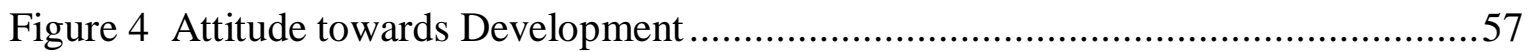

Figure 5: Preferred Development Option [Demographic breakdown] ..............................59

Figure 6: Preferred Development Option.................................................................. 60

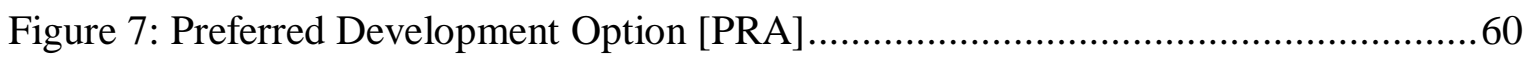

Figure 8: Mathematically adjusted to women voice...................................................61

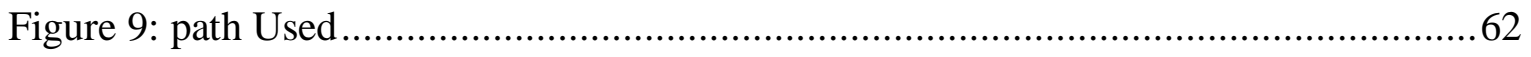

Figure 10:Attitudes to Roads [interviews] $\quad$ Figure 11 :Interviewer’s impression

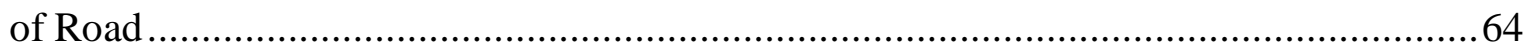

Figure 12:Received aid for work up the hill during the famine of the 1980s ...................64 


\section{References}

Institute of Development Studies (1983). Drought and famine relief in Ethiopia. Disasters 7(3): 164-168.

Abegunrin, O. (2006). The military and Nigerian political economy in the global System. Africa's Development in Twenty-first Century:Pertinent Socio-Economic and Development Issues. K. Konadu-Agyemang and K. Panford (eds). Burlington, Ashgate.

Adedeji, A. (1989)._Towards a Dynamic African Economy. London, Frank Cass.

Adedeji, A. (2006). Fifty Key Thinkers on Development. New York, Routledge.

Anacleti, O. (2002). Research into local culture: implications for participatory development. Development and Culture. D. Eade (ed). London, Oxfam.

Ascroft, J. (1994). Participatory decision making: a parable. Participatory Communication: Working for change and development. S. A. White, K. S. Nair and J. Ascroft (eds). New Delhi, Sage Publication India Pvt Ltd.

Ascroft, J. and S. Masilela (1994). Participatory decision making in Third World development. Participatory Communication: Working for Change and Development. Shirley A. White, K. S. Nair and J. Ascroft (eds). New Delhi, Sage.

Ashenafi, M. (2003). Ethiopia: process of democratization and development Human Right Under African Constitutions: Realizing the Promise for Ourselves. A. A. Anna'im(ed). Philadelphia, University of Pennsylvania Press.

Beckingham, C. F. and G. W. B. Huntingford (eds) (1954). Some records of Ethiopia 1593 -1646. London, Printed for The Hakluyt Society.

Benmaamar, M. (2006). Financing of road maintenance in Sub-Saharan Africa: reforms and progress towards second generation road funds. Road Management and Financing - RMF Series No:6. World Bank, SSATP website. 
http://www4.worldbank.org/afr/ssatp/Resources/SSATP-DiscussionPapers/dp06.pdf.

Bennett, P. (1998). Famine :The World Reacts_London, Belitha Press.

Bevan, P. (1997). Poverty in Ethiopia. Prepared for the Overseas Development Administration(March): 1-22.

Bible, Ed. (1992). Good News Bible: Today's English Version. Wellington, The Bible Society in New Zealand.

Borton, J. (1995). Ethiopia: NGO consortia and coordination arrangements, 1984 - 1991. Meeting Needs: NGO Coordination in Practice. J. Borton (ed). London, Earthscan.

Boserup, E. (1983). The impact of scarcity and plenty on development Hunger and History. R. I. Rotberg and T. K. Rabb (eds). Cambridge, Cambridge University Press.

Bratton, M. (1989). The politics of Government - NGO relations in Africa. World Development 17(4).

Braun, J. V., T. Teklu, et al. (1998). Famine in Africa: Causes, responses, and prevention. Baltimore, The Johns Hopkins University Press.

Burkey, S. (1993). People First : A Guide to Self-Reliant, Participatory Rural Development. London, Zed Books.

Cervero, R. (1990). Accessibility and Third World rural development: A case study of Sumatra. Review of Urban and Regional Development Studies 2(2): 125 -38.

Chabal, P. and J.-P. Daloz (1999). African issues: Africa Works Disorder Political Instrument. Indiana, University of Indiana.

Chambers, R. (1983). Rural Development: Putting the Last First. London, Longman.

Chambers, R. (1995). Paradigm shifts and the practice of participatory research and 
development. Power and Participatory Development: Theory and practice. N. Nelson and S. Wright (eds). London, Intermediate Technology Publication.

Chambers, R. (1995). Poverty and livelihood: Whose reality counts? Institute of Development Studies.

Chambers, R. (1997). Whose reality counts? Putting the First Last_London, Intermediate Technology Publication.

Chetkov-Yanoov, B. (1986). Participation as a means to community cooperation. Community and Cooperatives in Participatory Development. Y. Levi and H. Litwin (eds). Brookfield, Gower Publishing Company.

Cleaver, F. (2001). Institutions, agency and the limitations of participatory approaches to development. Participation The New Tyranny? B. Cooke and U. Kohari (eds). London, Zed Books.

Cooke, B. and U. Kothari (eds) (2001). The Case for Participation as Tyranny. Participation: The New Tyranny? London, Zed Books.

Coolican, H. (2004). Research Methods and Statistics in Psychology. London, Hodder and Stoughton.

Cornwall, A. (2000). Making a Difference? Gender and participatory development. Institute of Development Studies Working Paper 378.

Crawley, H. (1998). Living up to the empowerment claim? The potential of PRA. The Myth of Community : Gender issues in participatory development. I. Guijit and M. K. Shah (eds). London, Intermediate Techonology Publications.

Currey, B. and G. Hugo (1984). Famine as a Geographical Phenomenon. Boston, A Member of the Kluwer Academic Publisher Group.

DeRose, L. and S. Millman (1998). Introduction. Tokyo, United Nation University Press. Devereux, S. (2003). Conceptualising Destitution Institute of Development Studies Working Paper 216. 
Devereux, S. (ed) (2007). From 'old famines' to 'new famines'. The New Famines: Why famines persist in an era of globalisation. New York, Routledge.

Devereux, S. and Z. Tiba (2007). Malawi's first famine, 2001 -2002. The New Famines: Why famines persist in an era of globalization. S. Devereux (ed). New York, Routledge.

Dnews, I. F. R. T. (2002). Viability of community transport solutions International Forum for Rural Transport and Development 9(3): 1-4.

Dnews, I. F. R. T. (2003). Transport and poverty. International Forum for Rural Transport and Development 10(3): 1-4.

Dnews, I. F. R. T. (2006). Understanding rural transport hubs International Forum for Rural Transport and Development 13(1): 1-4.

Dyson, T. (1996). Population and Food :- Global Trends and Future Prospects. London, Routledge.

Edkins, J. (2007). The criminalization of mass starvations: From natural disaster to crime against humanity. The New Famines: Why famines persist in an era of globalisation. S. Devereux (ed). New York, Routledge.

Edmonds, G. (1998). Accessibility planning, case study: rural travel and transport in Malawi. Integrated Rural Accessibility Planning 5(4): 1-4.

Esteva, G. (2001). Development. The Development Dictionary. W. Sachs (ed). London, Zed Books.

Fouracre, P. (2001). Transport and sustainable rural livelihoods. Rural Travel and Transport Program 5(3:a): 1-9.

Francisco, A. J. and J. K. Routray (1992). Road Transport and Rural Development. Bangkok, Asian Institute of Technology. 
Frandin, D. B. (1986). Disaster Famines. Chicago, Childrens Press.

Franzel, S. and H. v. Houten (1992). Research with Farmers: Lesson from Ethiopia. Wallingford, C. A. B International.

Gaventa, J. (2004). Towards participatory governance: assessing the transformative possibilities. Participation: From Tyranny to Transformation? S. Hickey and G. Mohan (eds). London, Zed Books.

Gilkes, P. (1975). The Dying Lion: Feudalism and Modernization in Ethiopia. London, Julian Friedmann Publisher Ltd.

Gillespie, A. (2001). The Illusion of Progress. UK, Earthscan Publishers Ltd.

Githinji, M. w. and G. Mersha (2007). Untying the gordian knot: The question of land reform in Ethiopia. Land, Poverty and Livelihoods in an Era of Globalization: Perspectives from developing and transition countries. a. H. Akram-Lodhi, S. M. B. Jr and C. Kay (eds). New York, Routledge.

Green, D. (1995). Setting a course for development. Geographical Magazine 67( 5): 3-16.

Greenfield, R. (1965). Ethiopia: A New Political History. London, Pall Mall Press.

Guijt, I. and M. K. Shah (eds) (1998). Waking up to power, conflict and process. The Myth of Community: Gender issues in participatory development. London, Intermediate Technology Publications.

Hagerstrand, T. (1987). Human interaction and spatial mobility: Retrospect and prospect. Transport Planning in the Changing World. P. Nijkamp and S. Reichman (eds). Aldershot, Gower Publishing Company: 11 - 29.

Haile, N., D. Tsegaye, et al. (2004). Research and Development on Dryland and Husbandry in Ethiopia. N. Haile, D. Tsegaye and T. Teka (eds). Mekelle, Mekelle University.

Hameso, Y. S. (2004). The Sidama nation and the solidarity of colonised nations in 
Ethiopia. State Crisis, Globalisation and National Movements in North-East Africa. A. Galata (ed). London, Routledge.

Hancock, G. (1985). The Challenge of Hunger. London, Victor Gollancz LTD.

Hand, F. (1999). Negotiating boundaries in the Horn of Africa. Borderlands :Negotiating Boundaries in Post-Colonial Writing. M. Rrif-Hulser (eds). Amsterdam, Rodopi.

Harvey, p. (1997). Rehabilitation in complex political emergencies: Is rebuilding civil society the answer? Istitue of Development Studies 60(Dec): 1-49.

Heymann, J. H. (1965). Objective of transportation. Transport Investment and Economic Development. G. Fromm (ed). Washington, The Bookings Institution.

Hickey, S. and G. Mohan (eds) (2004). Towards participation as transformation: critical themes and challenges. Participation: From tyranny to transformation? London, Zed Books.

Hilling, D. (1996). Transport and Developing Countries. New York, Routledge.

Holden, S. and H. Yohannes (2001). Land redistribution, tenure Insecurity, and intensity of production: A study of farm households in Southern Ethiopia. International Food Policy Research Institute Working paper 21: 1-39.

Hope, K. R. (1996). Title Development in the Third World : from Policy Failure to Policy Reform. Armonk, M.E. Sharpe.

Howe, P. and S. Devereux (2004). Famine intensity and magnitude scales: A Proposal for an instrumental definition of famine Disasters 28(4): 353 - 372.

Idris, A. (2004). The radicalised and islamicised Sudanese state and the question of Southern Sudan. State Crises, Globalisation and National Movements in NorthEast Africa. A. Jalata (ed). London, Routledge.

Ihnovbere, J. O. (2001). The state and ethnicity in Africa. The Issue of Political Ethnicity in Africa : Contemporary Perspectives on Developing Society. E. I. Udogu (ed). 
Jesman, C. (1963). The Ethiopia Paradox. London, Oxford University Press.

Kalb, D., W. Pansters, et al. (eds) (2004). Globalization and Development : Themes and Concepts in Current Research. Boston, Kluwer Academic Publishers: 1-8.

Kalu, K. A. (2001). Ethnicity and political economy of Africa: A conceptual analysis. The Issue of Political Ethnicity in Africa: Contemporary Perspectives on Developing Societies. E. I. Udogu (eds). Sydney, Ashgate.

Kumar, G. (1987). Ethiopian Famine 1973-1985: A Case-Study. Helsinki, Wider Publication.

Kumar, S. (2002). Methods for Community Participation : a Complete Guide for Practitioners. London, ITDG.

Lane, J. (1995). Non-governmental organizations and participatory development: the concept in theory versus the concept in practice. Power and Participatory Dvelopment: Theory and practice. N. Nelson and S. Wright (eds). London, Intermediate Technology Publications.

Lappe, F. M. and J. Collins (1986). World Hunger Twelve Myths. New York, Grove Weidenfeld.

Lautze, S. and D. Maxwell (2007). Why do famines persist in the Horn of Africa? Ethiopia, 1999-2003. The New Famines: Why famines persist in an era of globalization. S. Devereux (ed). New york, Routledge.

Leinbach, T. R. (1975). Transportation and the development of Malaya. Annals of the Association of American Geographers 65(2): 270 - 282.

Leslau, W. (1992). Concise Amharic Dictionary. Berkeley, University of California Press.

Leurs, R. (1995). Reflection on the Perceived Impacts, Quality and Contextual Challenges of Participatory Rural Assessment (PRA) in South Asia. Birmingham, I.S.B.M. 
Lyttelton, A. (2002). Liberal and Fascist Italy. Auckland, Oxford Univrsity Press.

MacGregor-Hastie, R. (1963). The Day of the Lion: The Life and Death of Fascist Italy 1922-1945. New York, Coward-McCann.

Mariam, M. W. (1986). Rural vulnerability to famine in Ethiopia:1958-1977. London, Intermediate Technology Publications.

Markham, C. R. (1869). A History of The Abyssinian Expedition. London, Macmillan And Co.

McDonagh, J. (2006). Transport policy instruments and transport-related social exclusion in rural Republic of Ireland Journal of Transport Geography_14(5): 355-366.

Messer, E. (1998). Conflict as a Cause of Hunger. Tokyo, United Nations University Press.

Milas, S. and J. A. Latif (2000). The political economy of complex emergency and recovery in Northern Ethiopia Disasters 24(4): 363 - 379.

Mopati, T. and G. Prinsen (2002). Ethnicity and participatory development methods in Botswana: Some participants are to be seen and not heard. Development and Culture. D. Eade (ed). Great Britain, Oxfam.

Morgan, P. (2004). Italian Fascism 1915-1945. New York, Palgrave-Macmillan.

Mosse, D. (2001). 'People's knowledge', participation and patronage: operation and representations in rural development. Participation The New Tyranny? B. Cooke and U. Kothari (eds). London, Zed Books.

Mosse, D. (2005). Cultivating Development : An Ethnography of Aid Policy and Practice. London, Pluto Press.

Nelson, N. and S. Wright (eds) (1995). Participation and power. Power and Participatory Development.. London, Intermediate Technology Publications. 
News, B. (2007) Ethiopia Rings in New Millennium. http:// news .bbc.co.uk /2/hi/ africa/6990298.stm (12/09/07).

Njenga, P. and A. Davis (2003). Drawing the road map to rural poverty reduction. Transport Reviews 23(2): 217-241.

Nyasulu, J. K. (2000). Transport, taxation and economic policies. International Forum for Rural Transport and Development 8(2): 1-4.

Nyerere, J. (1998). Good Governance for Africa. London, Third World Network.

Omari, A. H. (1993). Beyond the Civil military dichotomy in Africa: the case of Tanzania. Sub-Sahara Africa: A Sub-Continent in Transition. R. A. Siddiqui (ed). Sydney, Brookfield.

Oxfam and Saferworld (2007). Africa's missing billions. UK October.

Pankhurst, A. (1992). Resettlement and Famine in Ethiopia: The Villages' Experience. Munchester Munchester University Press.

Pankhurst, R. K. P. (ed) (1967). The Ethiopian Royal Chronicles. London, Oxford University Press.

Parker, B. (1995). Ethiopia: Breaking New Ground. Oxford, Oxfam.

Pieterse, J. N. (2000). After post-development. Third World Quarterly 21: 175-191.

Pottier, J. (2003). Negotiating local knowledge: An introduction. Negotiating Local knowledge: Power and Identity in Development. J. Pottier, A. Bicker and P. Sillitoe (eds). London, Pluto Press.

The Hunger Project (1985). Ending Hunger: An Idea Whose Time Has Come. Sydney, Praeger Scientific.

Raffaele, P. (2007 ). Keepers of the lost ark? Smithsonian Magazine. December. 
Rahmato, D. and M. Ayenew (2006). Electoral assistance and democratic transition in Ethiopia. Promoting Democracy in Postconflict Societies. J. d. Zeeuw and K. Kumar (eds). London, Lienne Rienner Publishers.

Rahnema, M. (2001). Participation. The Development Dictionary. W. Sachs (ed). London, Zed Books.

Robinson, W. I. (2004). Global capitalism and the Oromo liberation struggle. State Crises, Globalisation and National Movements in North-East Africa. A. Jalata (ed). London, Routledge.

Sandbrook, R. (2000). Closing The Circle: Democratization and Development in Arica. London, Zed Books.

Schenk, Q. F. and E. L. Schenk (1987). Ethiopia. Social Welfare in Africa. J. Dixon (ed). London, Croom Helm Ltd.

Schmale, M. (1993). The Role of Local Organizations in Third World Development. Sydney, Avebury.

Simon, D. (1996). Transport and Development in The Third World. London, Routledge. Smith, B. C. (2003). Understanding Third World Politics: Theories of Political Change and Development. Hampshire, Palgrave Macmillan.

Spencer, P. (2004). Keeping tradition in good repair: The evolution of indigenous knowledge and the dilemma of development among pastoralists,. Development and Local Knowledge. A. Bicker, P. Sillitoe and J. Pottier (eds). London, Routledge.

Stedman, S. J. and T. Lyons (2004). Conflict in Africa. Democratic Reform in Africa: The Quality of Progress. E. Gyimah-Boadi (ed). London, Lynne Rienner.

Steven (2006) 1935-1980s: The reign of Haile Selassie in Ethiopia: Africa Anarchist Federation Ethiopia 1960s 1970s countries monarchy politicians.

http://libcom.org/history/1935-1980s-the-reign-of-haile-selassie-in-ethiopia 
Strecker, I. (1994). Glories and agonies of the Ethiopia. Social Anthropology 2( 3): 303312.

Strong, J. (1901). Strong's Cxhaustive Concordance of The Bible Massachusetts, Hendrickson Publishers: 312.

Thomson, A. (2004). An Introduction to African Politics. London, Routledge.

Thomson, B. (1975). Ethiopia the Country That Cut off Its Head. London, Robson Books Ltd.

Udogu, E. I. (ed) (2001). General introduction. The Issue of Political Ethnicity in Africa: Conemporary Perspectives on Developing Society. Sydney, Ashgate.

Waal, A. d. (2007). Aids, hanger and destitution: Theory and evidence for the ' new variant famines' hypothesis in Africa. The New Famines: Why famines persist in an era of globalization. S. Devereau (ed). New York, Routledge.

Waktola, A. (1999). Exploratory Study of two regions in Ethiopia to Identify target areas and partners for intervention The Drylands Coordination Group (DCG) 6.

Walle, N. V. D. (2001). ㅅfrican Economies and The Politics of Permanent Crisis 19791999. Cambridge Cambridge University Press.

Watkins, S. C. and E. v. d. Walle (1983). Nutrition, mortality and population size: Malthus' court of last resort. Hunger and History: The Impact of Changing Food Production and Cnsumption Patterns on Society. R. I. Rotberg and T. K. Rabb (eds). Cambridge, Cambridge University Press.

Westphal, E. (1974). Pulses in Ethiopia, Their Taxonomy and Agricultural Significance. Wageningen, Centre for Agricultural Publishing and Documentation.

Wilson, G. W. (1970). The Role of transportation in regional economic growth. Transportation and Regional Development; Proceedings of a Conference. E. W. Tyrehniewicz and O. P. Tangri (eds). Winnipeg, Center of Transportation Studies, University of Monitoba. 
Young, A. (2005). Poverty, hunger and population policy: linking Cairo with Johannesburg The Geographical Journal 171(1): 83-95. 